\title{
Siting of an MRS Facility: \\ Identification of a \\ Geographic Region that \\ Reduces Transportation \\ Requirements
}

\author{
G. M. Holter \\ J. L. Braitman
}

April 1985

Prepared for the U.S. Department of Energy under Contract DE-AC06-76RLO 1830

Pacific Northwest Laboratory

Operated for the U.S. Department of Energy

by Battelle Memorial Institute 


\title{
DISCLAIMER
}

This report was prepared as an account of work sponsored by an agency of the United States Government. Neither the United States Government nor any agency thereof, nor any of their employees, makes any warranty, express or implied, or assumes any legal liability or responsibility for the accuracy, completeness, or usefulness of any information, apparatus, product, or process disclosed, or represents that its use would not infringe privately owned rights. Reference herein to any specific commercial product, process, or service by trade name, trademark, manufacturer, or otherwise, does not necessarily constitute or imply its endorsement, recommendation, or favoring by the United States Government or any agency thereof. The views and opinions of authors expressed herein do not necessarily state or reflect those of the United States Government or any agency thereof.

\author{
PACIFIC NORTHWEST LABORATORY \\ operated by \\ BATTELLE \\ for the \\ UNITED STATES DEPARTMENT OF ENERGY \\ under Contract DE-AC06-76RLO 1830
}

\begin{tabular}{|c|c|}
\hline \multicolumn{2}{|c|}{ Printed in the United States of America } \\
\hline \multicolumn{2}{|c|}{ Available from } \\
\hline \multicolumn{2}{|c|}{ National Technical Information Service } \\
\hline \multicolumn{2}{|c|}{ United States Department of Commerce } \\
\hline \multicolumn{2}{|c|}{ S285 Port Royal Road } \\
\hline \multicolumn{2}{|c|}{ Springfield, Virginia 22161} \\
\hline \multirow{2}{*}{\multicolumn{2}{|c|}{$\begin{array}{l}\text { NTIS Price Codes } \\
\text { Microfiche } \mathrm{A01}\end{array}$}} \\
\hline & \\
\hline \multicolumn{2}{|c|}{ Printed Copy } \\
\hline & Price \\
\hline Pages & Codes \\
\hline 001-025 & A02 \\
\hline $026-050$ & A03 \\
\hline 051-075 & A04 \\
\hline 076-100 & A05 \\
\hline $101-125$ & $A 06$ \\
\hline $126-150$ & A07 \\
\hline $151-175$ & $\mathrm{~A} 08$ \\
\hline $176-200$ & A09 \\
\hline $201-225$ & A010 \\
\hline $226-250$ & A011 \\
\hline 251-275 & A012 \\
\hline $276-300$ & A013 \\
\hline
\end{tabular}


SITING OF AN MRS FACILITY: IDENTIFICATION OF A GEOGRAPHIC REGION THAT REDUCES

TRANSPORTATION REQUIREMENTS

G. M. Holter

J. L. Braitman

Apri1 1985

Prepared for

the U.S. Departinent of Energy

under Contract DE-AC06-76RLO 1830

Pacific Northwest Laboratory

Richland, Washington 99352 


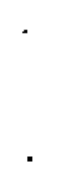




\section{ACKNOWLEDGMENTS}

The authors gratefully acknowledge the assistance provided by a number of individuals at Pacific Northwest Laboratory (PNL) during the course of this study. R. J. Hall of the MRS Program Office provided overall programmatic guidance. R. E. Rhoads and G. W. McNair provided technical support for the transportation analyses performed. A. L. Slavich provided analytical and graphics support. Editorial review and assistance was provided by $C$. A. Counts. The Word Processing team supervised by M. M. Hale prepared the final manuscript.

A number of individuals at PNL provided a technical review of the study. Although too numerous to mention, their assistance was invaluable. 


\section{CONTENTS}

ACKNOWLEDGMENTS

i i

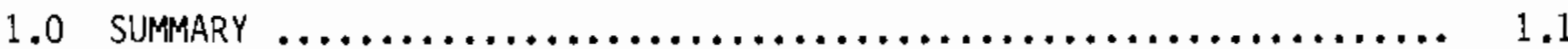

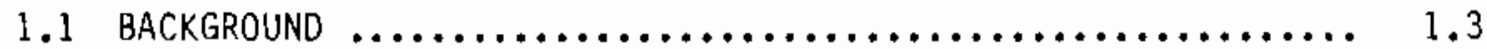

1.2 APPROACH TO MRS SITE SCREENING $\ldots \ldots \ldots \ldots \ldots \ldots \ldots \ldots \ldots \ldots \ldots . . . \ldots \ldots$

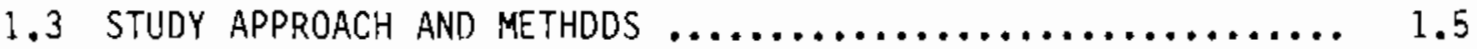

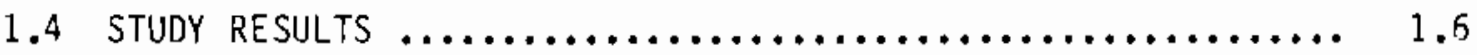

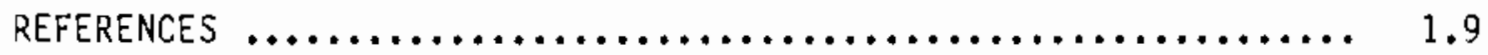

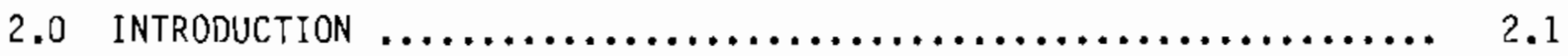

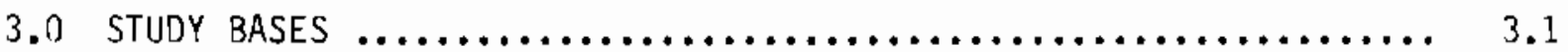

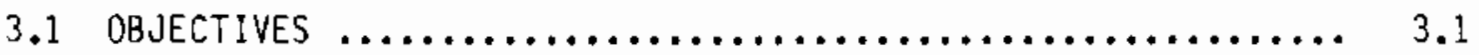

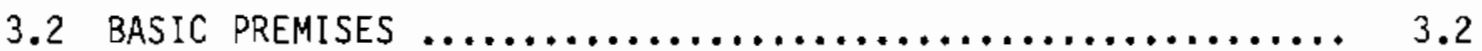

4.0 InTEgRated fEDERAL WASTE MANAGEMENT SYSTEM $\ldots \ldots \ldots \ldots \ldots \ldots \ldots \ldots . . \ldots$

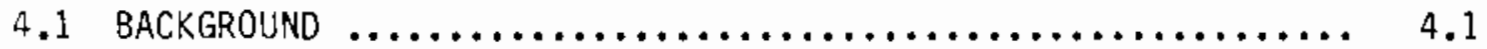

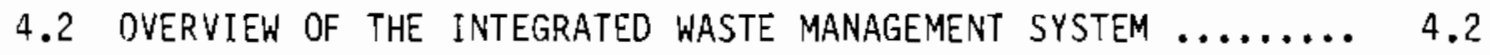

4.3 WASTE MANAGEMENT SYSTEM LOGISTICS CONSIDERATIONS $\ldots \ldots \ldots \ldots .4 .4$

4.3 .1 Location of Facilities $\ldots \ldots \ldots \ldots \ldots \ldots \ldots \ldots \ldots \ldots .4 .4$

4.3 .2 MRS Facility 0perations $\ldots \ldots \ldots \ldots \ldots \ldots \ldots \ldots \ldots .4 .6$

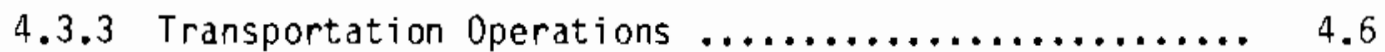

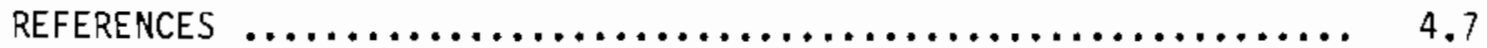

5.0 ANALYTICAL APPROACH AND METHODS $\ldots \ldots \ldots \ldots \ldots \ldots \ldots \ldots \ldots \ldots \ldots \ldots \ldots \ldots \ldots$

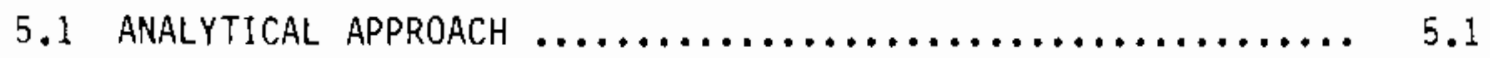

5.1.1 Repository Locations .................... 5.2

5.1.2 Lifetime Spent Fuel Throughput of the MRS Facility .. 5.3 
5.1.3 Magnitude of the Volume Reduction from Spent Fuel

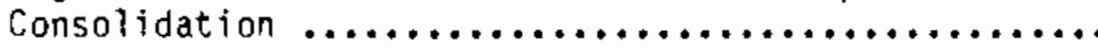

5.1.4 Spent Fuel Shipping Cask Capacities ............ 5.4

5.1 .5 Use of Single-Cask or Multiple-Cask Shipments ...... 5.4

5.1.6 Transportation Modes to be Used ............... 5.5

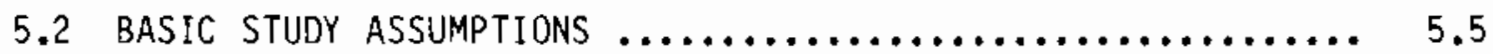

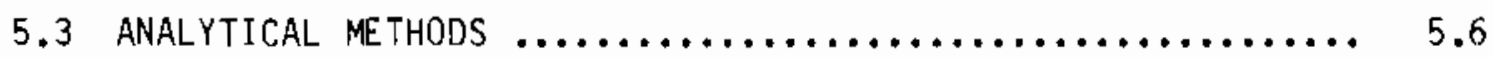

5.3 .1 Identification of the Spent Fuel $\ldots \ldots \ldots \ldots \ldots \ldots \ldots . . \ldots .7$

5.3.2 Identification of Minimum Shipment Miles Location and Travel Distance Contours ..................... 5.8

5.3.3 Calculation of Total Shipment Miles ............. 5.9

5.4 ANALYTICAL UNCERTAINTIES $\ldots \ldots \ldots \ldots \ldots \ldots \ldots \ldots \ldots \ldots \ldots \ldots \ldots$

5.5 EXAMPLE ILLUSTRATION OF SITING ANALYSES PERFORMED ....... 5.10

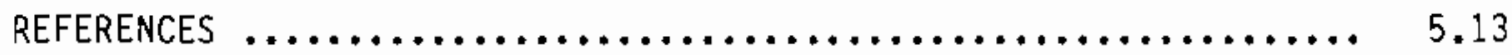

6.0 SENSITIVITY OF THE SITING REgION TO WASTE SYSTEM LOGISTICS $\ldots \ldots . . \quad 6.1$

6.1 SENSITIVITIES FOR A SINGLE REPOSITORY LOCATION $\ldots \ldots \ldots \ldots \ldots .6 .1$

6.1 .1 Spent Fuel Rod Consolidation ................. 6.4

6.1 .2 Multiple-Cask Shipments $\ldots \ldots \ldots \ldots \ldots \ldots \ldots \ldots \ldots . \ldots . . \ldots$

6.1 .3 Shipping Cask Capacities .................... 6.8

6.1.4 Sensitivities to Combination of Factors .......... 6.11

6.2 SENSITIVITIES TO CHANGES IN REPOSITORY LOCATION $\ldots \ldots \ldots \ldots \ldots .6 .11$

7.0 SENSITIVITY OF SHIPMENT MILES TO WASTE SYSTEM LOGISTICS $\ldots \ldots \ldots \ldots .1$

7.1 SPENT FUEL ROD CONSOLIDATION $\ldots \ldots \ldots \ldots \ldots \ldots \ldots \ldots \ldots \ldots \ldots \ldots \ldots \ldots \ldots \ldots$

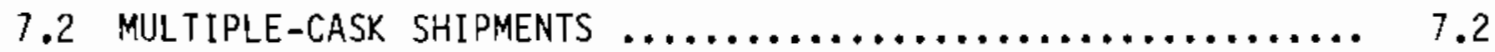

7.3 SPENT FUEL SHIPPING CASK CAPACITIES $\ldots \ldots \ldots \ldots \ldots \ldots \ldots \ldots \ldots . . \ldots$

7.4 COMBINATIONS OF LOGISTICS FACTORS $\ldots \ldots \ldots \ldots \ldots \ldots \ldots \ldots \ldots \ldots .4 .4$

7.5 SUMMARY SHIPMENT MILE SENSITIVITIES $\ldots \ldots \ldots \ldots \ldots \ldots \ldots \ldots \ldots . . \ldots$ 
8.0 CONCLUSIONS $\ldots \ldots \ldots \ldots \ldots \ldots \ldots \ldots \ldots \ldots \ldots \ldots \ldots \ldots \ldots \ldots \ldots \ldots \ldots, 8.1$

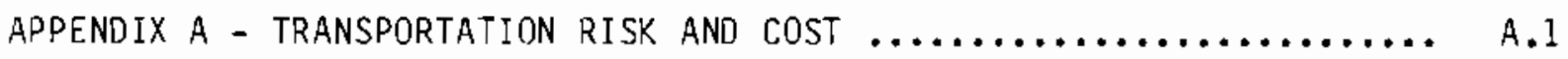

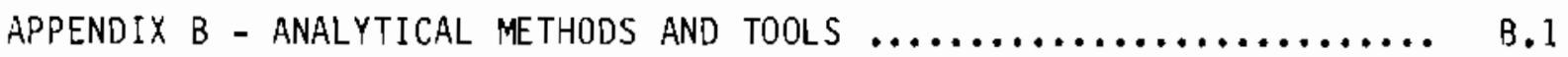

APPENDIX C - SPENT FUEL INFORMATION USED FOR SITING REgION ANALYSES ..

APPENDIX D - GEOGRAPHIC DISTRIBUTION OF SPENT FUEL $\ldots \ldots \ldots \ldots \ldots \ldots \ldots$. 0.1 
. 


\section{FIGURES}

1.1 The Preferred Siting Region for a Monitored Retrievable

Storage Facility ................................... 1.2

4.1 The Principal Components Within an Integrated Waste Management

System

5.1 Region which Minimizes Total Shipment Miles: Example Case ..... 5.12

5.2 Summary of Shipment Mile Totals Calculated for the Example

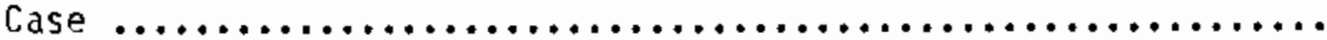

6.1 Minimum Distance Contours Assuming Single-Cask Shipments to and from the MRS Facility, No Spent Fuel Rod Consolidation, and the First Repository at BWIP

6.2 Minimum Distance Contours Assuming Single-Cask Shipments to and from the MRS Facjlity, Spent Fuel Rod Consolidation, (1.5:1) and the First Repository at BWIP

6.3 Minimum Distance Contours Assuming Single-Cask Shipments to and from the MRS Facility, Spent Fuel Rod Consolidation, (2:1)

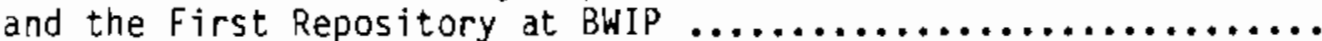

6.4 Minimum Distance Contours Assuming Single-Cask Shipments to and 3-Cask Shipments from the MRS Facility, No Spent Fuel Rod Consolidation, and the First Repository at BWIP

6.5 Minimum Distance Contours Assuming Single-Cask Truck or 3-Cask Rail Shipments to the MRS Facility, 5-Cask Shipments from the MRS Facility, No Spent Fuel Rod Consolidation, and the First Repository at BWIP

6.6 Minimum Distance Contours Assuming Single-Cask Shipments to and from the MRS Facility, No Spent Fuel Rod Consolidation, the First Repository at BWIP, and DOE Generic Casks ...........

6.7 Minimum Distance Contours Assuming Single-Cask Shipments to and from the MRS Facility, No Spent Fuel Rod Consolidation, and the First Repository at Richton, Mississippi .............

6.8 Minimum Distance Contours Assuming Single-Cask Shipments to and from the MRS Facility, Spent Fuel Rod Consolidation, and the First Repository at Richton, Mississippi

7.1 Impacts on Minimum Shipment Miles of Spent Fuel Rod Consolidation at the MRS Facility

7.2 Impacts of Multiple-Cask Shipments on Minimum Shipment Miles .... 7.2 
7.3 Impacts of Shipping Cask Capacities on Minimum Shipment Miles ... 7.3

7.4 Comparison of Minimum Total Shipment Miles for Five Repository Locations, Based on a "Representative" Set of Waste Management System Logistics Factors ........................... 7.4

8.1 The Preferred Siting Region for a Monitored Retrievabie Storage Facility ................................. 8.3 


\section{TABLES}

5.1 Ranges of Waste System Logistics Factors Used for Siting

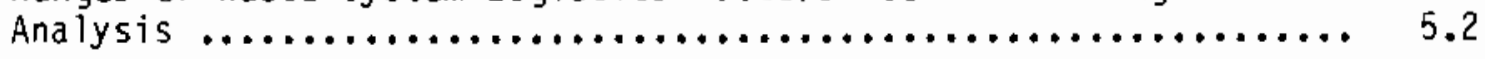

5.2 Waste System Logistics Factors Used for Example I1lustration of Siting Analyses $\ldots \ldots \ldots \ldots \ldots \ldots \ldots \ldots \ldots \ldots \ldots \ldots \ldots \ldots \ldots \ldots . \ldots \ldots \ldots$

5.3 Summary of Shipment Mile Totals Calculated for the Example Case .......................................... 5.14

7.1 Comparison of Total Shipment Miles for Selected Combinations of Waste System Logistics Factors

7.6 


\subsection{SUMMARY}

The study reported here was undertaken as part of the site screening and evaluation activities for the Monitored Retrievable Storage (MRS) Program of the Office of Civilian Radioactive Waste Management (OCRWM), Department of Energy (DOE). Its primary purpose was to determine:

1. The location and shape of a preferred geographic region within which locating an MRS facility would minimize total shipment miles for spent fuel transported through the MRS facility to a repository.

2. The sensitivity of the location and shape of this region and the reduction in total shipment miles to possible variations in waste management system logistics.

As a result of this analysis, a geographic region has been identified which is preferred for siting an MRS facility. This region, which will be referred to as the preferred region in this study, is shown in Figure 1.1. Siting an MRS facility in the preferred region will limit total shipment miles (i.e., the total miles traveled for all shipments of spent fuel) to and from the MRS facility to within $20 \%$ of the lowest achievable. The region is preferred for a mixed truck/rail system of transport from reactors to the MRS facility. It is assumed that rail will be used to ship spent fuel from the MRS facility to a geologic repository for disposal.

Siting an MRS facility in the preferred region will reduce total shipment miles for all currently considered system logistics options which include an MRS facility in the system. These options include: any first repository location, the possible range of spent fuel consolidation at the MRS, use of multicask or single-cask train shipments, use of current or future spent fuel transport casks, servicing only the first or both the first and second repositories, and shipment of fuel from western reactors either through the MRS facility or to a western facility (a second, smaller MRS facility or the first repository). 


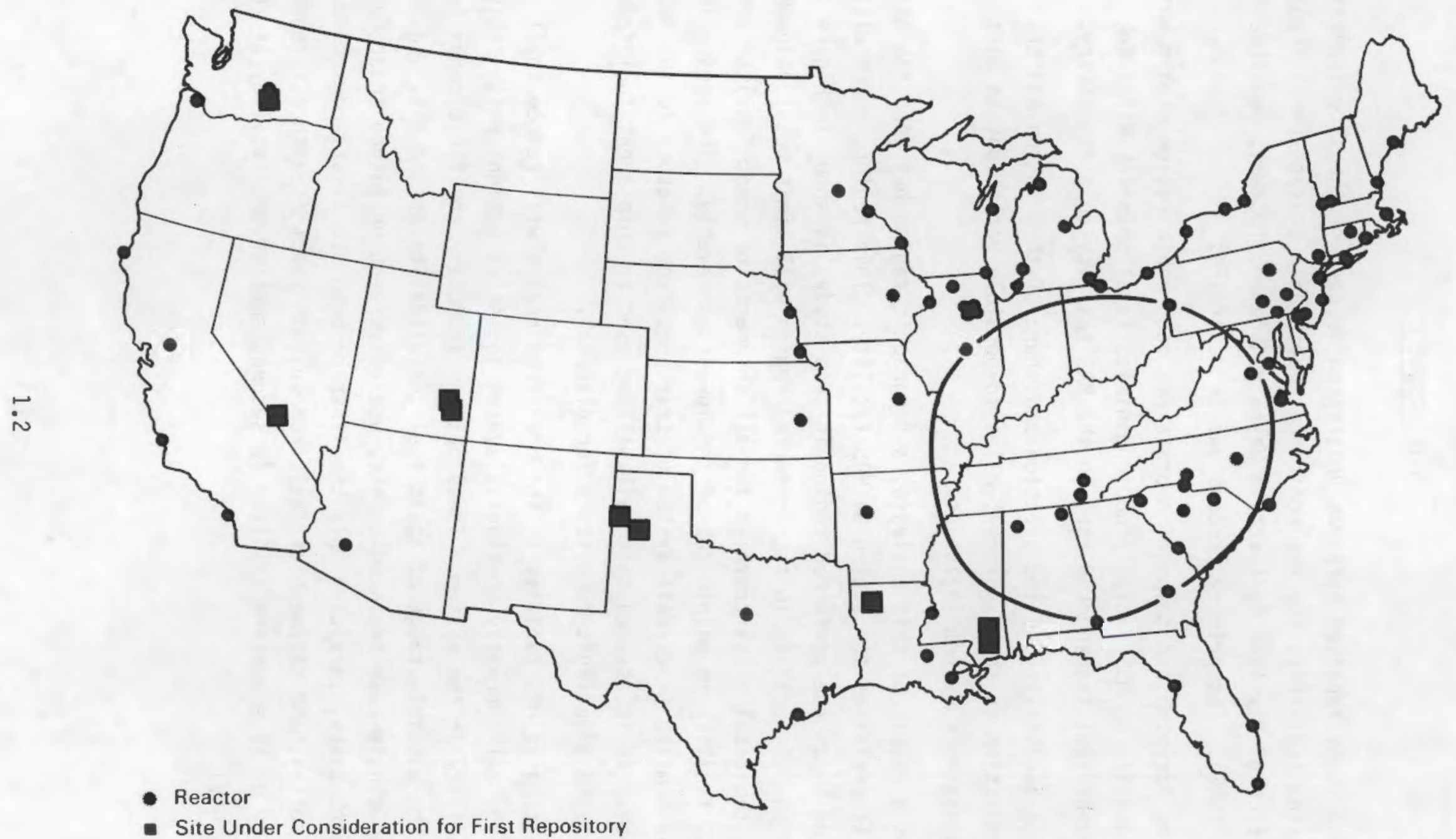

- Site Under Consideration for First Repository

FIGURE 1.1. The Preferred Siting Region for a Monitored Retrievable Storage (MRS) Facility 


\subsection{BACKGROUND}

The MRS facility, if authorized by Congress, would serve as a centralized spent fuel and nuclear waste preparation and packaging facility. (1) within the context of the waste management system current7y proposed by OCRWM, the MRS facility will

1. receive spent fuel from most or possibly all reactors;

2. consolidate and package spent fuel (overpacking of the fuel for permanent disposal in a repository could be included if further studies show that overpacking would best be performed at the MRS facility); and

3. store fuel temporarily pending shipment to the repository.

The MRS Program was developed pursuant to the Nuclear Waste Policy Act of 1982 which directs the Department to "...complete a detailed study of the need for and feasibility of, and to submit to Congress a proposal for the construction of one or more monitored retrievable storage facilities for high-level radioactive waste and spent nuclear fuel...."(2) The Act directs that the proposal include, "...for the first such facility, at least three alternative sites and at least five alternative combinations of such proposed sites and facility designs..." as well as a recommendation of "...the combination among the alternatives that the Secretary deems preferable...."

\subsection{APPROACH TO MRS SITE SCREENING}

Siting any facility involves setting objectives to help distinguish which parcels of land can help achieve the goals of the facility or associated program. Establishing appropriate screening factors can help to eliminate large tracts of unsuitable or less desirable lands without having to perform detailed and costly evaluations. Screening factors can also be used to identify lands which are more likely to achieve the desired goais than lands eliminated. For example, the primary set of criteria for locating a geologic repository involve assessments of the ability of the host geologic medium to contain the radionuclides over the period of time which they remain hazardous. 
The primary considerations in identifying a preferred and two alternative sites for an MRS facility are to locate sites:

1. where an MRS facility can be constructed in a safe, cost-effective and timely fashion, with minimal adverse impacts on the local community or environment, and

2. that will enhance the role of an MRS facility as an integral part of the Federal nuclear waste management system.

Because the MRS facility is based on engineered containment of the radioactive materials, performance of an MRS facility would be relatively independent of the specific conditions of the site. In this respect, an MRS facility is quite different from a repository, which is strongly dependent on site conditions for successful performance. Because of this relative independence from specific site conditions, an MRS facility could be successfully built and operated at any of a large number of sites throughout the U.S.

Reduction of total shipment miles is a logical dominant objective in identifying suitable MRS sites. Transportation of spent fuel and other wastes is a major function of the waste management system which most directly interfaces with the public. In commenting on past and current DOE plans and activities, interested groups and individuals have repeatedly identified transportation as a concern regarding the waste management system.

The distribution of reactors (and therefore spent fuel), the location of potential first repository sites, and the functions of the proposed MRS facility all support the logic for using reduction of total shipment miles to identify preferred lands for siting an MRS facility. Specifically, the vast majority of reactors and spent fuel is located in the midwest and eastern parts of the U.S. The first repository locations are located in a crescent-shaped region in the western, southwestern, and southern portions of the country. The MRS facility will function to combine a large number of relatively smaller shipments of spent fuel into fewer, larger shipments. Thus, locating an MRS facility near the majority of reactors would provide system advantages in reducing the total number of shipment miles. 
The purpose of this analysis is to determine if applying the logic described above results in identifying a preferred geographic region appropriate for siting an MRS facility. An appropriate region would be large enough to provide confidence of finding many potentially suitable MRS sites within its boundaries. Appropriateness also refers to whether or not the region maintains its "preferred" status across the range of potential system logistics choices that could emerge in the future as system implementation plans are developed. Such an appropriate region was identified as a result of the analyses described in this report.

\subsection{STUDY APPROACH AND METHODS}

As indicated, this study was undertaken to identify a preferred geographic region within which locating an MRS facility substantially reduces total shipment miles. The region must maintain its preferred status regardless of future system logistics choices. Thus, analyses were performed for a variety of different logistics combinations.

A number of decisions that will affect the logistics characteristics of the Federal waste management system are yet to be made. Because these logistics considerations will, in turn, affect the number and geographic distribution of spent fuel shipments within the waste management system, a number of possible combinations of logistics factors were examined.

For each combination of logistics factors that was analyzed, calculations were made to identify contours of total shipment miles for potential MRS locations. The region outlined by these contours varied in location, size, and shape depending on the specific combination of logistics factors considered.

The following variations in logistics factors were considered:

- repository location (first 9 potential repository sites)

- lifetime spent fuel throughput of the MRS facility (from 70,000 MTU to all spent fuel projected to be discharged from currently planned or operating reactors, $\sim 100,000$ MTU)

- degree of volume reduction from spent fuel rod consolidation at the MRS facility (from no volume reduction to a $2: 1$ reduction) 
- spent fuel shipping cask capacities (current casks versus DOE generic casks)

- use of single-cask or multiple-cask shipments (up to 10 casks/train)

- transportation modes to be used (truck and rail).

Other logistics factors, such as receipt schedules for the spent fuel shipments, were not considered in these analyses. Although they may affect the operation of the waste management system, they are not of importance in determining total spent fuel shipment miles.

For this study, spent fuel was assumed to move through the system by rail whenever possible. However, some reactors are not equipped to handle the larger rail casks for spent fuel transport. Therefore, these reactors ( 30\%) are realistically limited to shipping spent fuel to the MRS facility by truck.

\subsection{STUDY RESULTS}

Based on the analyses performed for this study, a geographic region was identified within which locating an MRS facility will reduce total shipment miles for all spent fuel shipments throughout the waste management system. Specific sites within this region will be evaluated for suitability as MRS sites. Identification and evaluation of those sites will be documented in other reports.

Total shipment miles throughout the waste management system are reduced because functions and operations performed at the MRS facility will combine fuel into fewer shipments leaving the MRS facility for the repository than are received at the MRS facility from the reactors. There are three reasons for this:

1. Spent fuel assemblies arriving at the MRS facility in truck casks are shipped out in rail casks with capacities 6 to 9 times greater than the truck casks.

2. Spent fuel assemblies can be disassembled and consolidated into a smaller volume at the MRS facility, further increasing the amount of spent fuel in outbound casks. 
3. Rail shipments moving between the MRS facility and the repository can be optimized to reduce shipments by shipping multiple casks per train.

For any combination of repository location and waste management system logistics factors, the MRS facility location that would result in the lowest achievable total shipment miles lies along a line between the repository location and the centroid of the spent fuel shipments from the individual reactors. Contours can be drawn to show how total shipment miles increase with movement away from the minimum point. These contours define geographic regions within which locating an MRS facility would keep total shipment miles within a given percentage of the lowest achievable total.

If the MRS facility performs no fuel-combining function (e.g., spent fuel rod consolidation, multiple-cask shipments, conversion of truck shipments to rail shipments etc.), the location resulting in minimum total shipment miles is at the potential repository site. As functions are added to the MRS facility to combine the incoming fuel into fewer outgoing shipments, the point which minimizes total shipment miles moves toward the centroid of the shipments from the reactors, and the total-shipment-mile contours become closer together.

For this study, increases of $10 \%$ and $20 \%$ over the minimum achievable total shipment miles were selected for establishing contours. For all combinations of logistics factors and all repository locations, the common region bounded by the $20 \%$ contour is large enough to provide a substantial number of potential MRS-site choices, while providing substantial reductions in total shipment miles when compared to locating the MRS facility in some other area. The two contours in combination indicate the rate of change in total shipment miles as the potential MRS site is moved away from the minimum point.

For all currently feasible combinations of logistics factors, including the different possible first repository locations, a composite "preferred" siting region was defined by the intersection (i.e., overlapping) of the individual regions for each combination of logistics factors. This composite "preferred" siting region, which is somewhat smaller and more circular than the 
region that would be identified for any single combination of logistics factors, is located in the central-eastern portion of the U.S., as shown in Figure 1.1.

Locating an MRS facility in the preferred region identified in Figure 1.1 would reduce total shipment miles associated with spent fuel shipments throughout the waste management system. By locating an MRS facility within the preferred region, total shipment miles can be significantly reduced. The achievable reduction in the total shipment miles is dependent on the specific MRS location within the preferred region, the specific repository location, and the particular set of waste management system logistics factors considered.

The reduction in total shipment miles that can be achieved depends upon 1) the ratio of incoming and outgoing shipments, and 2) the distance between the centroid of spent fuel shipments from the reactors and the potential repository site. The greater this ratio and this distance, the larger the reduction in total shipment miles.

For a system with mixed truck/rail shipments from reactors to the MRS facility and rail shipments from the MRS facility to the repository, the range of achievable reductions in total shipment miles is from about $10 \%$ to about $60 \%$ of the total shipment miles that would occur in a system without an MRS facility. The smallest reduction is for 1) an MRS facility with no fuel-combining functions other than the exclusive use of rail shipments from the MRS facility to the repository (i.e., truck shipments will only be used from some reactors to the MRS facility), and 2) an assumed first repository located at Richton, Mississippi, the prospective repository location closest to the center of the reactors. The greatest reduction is for 1) an MRS facility that uses all of the fuel-combining functions (i.e., spent fuel rod consolidation, multiple-cask shipments to the repository) and 2) an assumed first repository located at Hanford, washington, the prospective repository location furthest from the center of the reactors. 
Within the range of currently considered system logistics options, siting an MRS facility within the preferred region would result in reduced total shipment miles within the waste management system:

- regardless of the location of the first repository receiving the spent fuel shipments from the MRS facility;

- whether or not fuel from the West Coast reactors (California, Oregon, Washington, and Arizona) is moved to an MRS facility in the preferred region or to some other facjlity in the west; and

- whether or not current-generation shipping casks or future-generation casks with greater capacities are used.

Therefore, locating an MRS facility within this preferred region would result in reduced total shipment miles given the foreseeable range of decisions that will ultimately be made about waste management system logistics.

\section{REFERENCES}

1. Office of Civilian Radioactive Waste Management. 1985. "The Integrated System for the Management of Spent Nuclear Fuel and High-Level Radioactive Waste," U.S. Department of Energy, Washington, D.C. (February 11, 1985).

2. Public Law 97-425, 96 Stat. 2201, 42 U.S.C. 10101 et seq. 


\subsection{INTRODUCTION}

In accordance with the provisions of the Nuclear Waste Policy Act of 1982 (NWPA), the Department of Energy (DOE) is conducting studies of Monitored Retrievable Storage (MRS) facilities for high-level radioactive waste and spent nuclear fuel. These studies were undertaken to determine the need for and feasibility of MRS facilities and to develop a proposal for the construction of one or more MRS facilities.

An important part of the MRS program is the selection of three potentially suitable sites for the construction of MRS facilities. This report describes a study which is part of the overall MRS site screening and evaluation process. This study was undertaken to assess whether locating an MRS facility within an identifiable geographic region would reduce total shipment miles for spent fuel transportation to and from an MRS facility. Such a region can then be used in screening potential MRS sites, to help reduce transportation activities within the waste management system.

Section 1 is a summary of the siting region study. It includes a brief discussion of the overall MRS siting process and provides background for discussion of the siting region analyses. Details supporting the summary are provided in the remaining sections of the report.

The primary bases for this study, including its objectives and the basic premises that were used, are discussed in Section 3. Section 4 provides a discussion of the overall nuclear waste management system, the role of an MRS facility within that system, and possible system logistics alternatives.

The description of the actual siting region analyses begins in Section 5 with a discussion of the analytical approach and methods used and the basic study assumptions. Based on this information, the sensitivities of the results of the siting region analyses to possible variations in the basic logistics of the overall waste management system are described in Sections 6 and 7.

The conclusions resulting from the siting region analyses are presented in Section 8. Detailed information supplementing that provided in the main body of the report is included in several appendices. 



\subsection{STUDY BASES}

Transportation of spent fuel and other wastes is a major function of the waste management system. Reduction of these transportation activities is desirable, provided that this reduction can be obtained without significant negative impacts on other aspects of the waste management system.

If location of an MRS facility within a specific geographic region would provide substantial reductions in the total shipment miles for all spent fuel shipments to and from the MRS facility, this geographic region (i.e., the preferred region) could be used as a primary criterion for discriminating among possible MRS sites throughout the U.S. Selection of a site within the preferred region would help to avoid unnecessary travel for spent fuel shipments moving within the waste management system.

The objectives of the study reported here and the basic premises used in carrying out the study are described in this section.

\subsection{OBJECTIVES}

This study has two related objectives:

Objective 1. To determine the location and shape of a preferred geographic region within which locating an MRS facility would minimize total shipment miles for spent fuel transported through the MRS facility to a repository.

Objective 2. To determine the sensitivity of the location and shape of the preferred region and the reduction in total shipment miles to possible variations in waste management system logistics.

For this study, reduction of total shipment miles within the waste management system was chosen as the measure for identifying a preferred geographic region for siting an MRS facility. These total shipment miles encompass the operating life of the MRS facility. The region identified should provide a reasonable number of possible sites from which to select three alternative 
sites, as required by the provisions of the NWPA, while providing substantial reductions in total shipment miles when compared to possible site locations in other regions.

The definition of various details and the development of implementation plans for the waste management system are currently under way. Because the detajls of the waste management system and its operation are not completely defined at this time, it is important to identify the sensitivities of the preferred region to a variety of logistics factors.

Factors that could have possible impacts on the shape and location of the preferred region include:

- the location of the repository or repositories that will receive the spent fuel from the MRS facility;

- the amount of spent fuel to be received at the MRS facility;

- the magnitude of the volume reduction to be obtained from spent fuel rod consolidation at the MRS;

- transportation modes to be used;

- spent fuel shipping cask capacities; and

- the use of single-cask or multiple-cask shipments.

The potential savings in total shipment miles resulting from locating an MRS facility in a specific region are also likely to vary with changes in these system logistics factors. Therefore, the sensitivities of such potential savings in shipment miles to possible changes in these system logistics factors are also analyzed.

The waste management systen, including the relevant logistics considerations, is discussed in Section 4 of this report.

\subsection{BASIC PREMISES}

In addition to the objectives described above, two basic premises were identified for use in carrying out this study. These premises are discussed below. 
Premise 1. Al1, or at least the majority, of the spent fuel from the utilities' existing nuclear power reactors will be shipped through an MRS facility prior to disposal at a repository.

This premise is based on the mission of the MRS facility as an integral part of the waste management system, as described in more detail in the subsequent section of this report. Although the results of this study are somewhat sensitive to the total amounts and sources of spent fuel considered, the general conclusions reached will not change significantly as long as a majority of the spent fuel from existing reactors is handled at the MRS facility. The spent fuel information used for this study represents a range of from $70,000 \mathrm{MTU}$ to al1 (about 100,000 MTU) of the fuel projected to be discharged from existing or currently planned reactors.

Premise 2. Reduction of total shipment miles will provide a desirable reduction in the transportation activities interface with the public, without resulting in undesirable penalties in terms of transportation costs or risks.

It is desirable to reduce shipment miles within the waste management system to provide comparable reductions in state and local resource requirements and frequency of spent fuel shipments on the rail and highway networks. These reductions can be achieved without incurring penalties in terms of either transportation costs or risks.

Rigorous projections of transportation risks and costs involve fairly detailed calculations and require route-specific information for accurate comparisons between different alternatives. However, risks are generally proportional to shipment miles, while cost is relatively insensitive to the location of the MRS facility.

Details regarding the relationship between shipment miles and transportation risk and cost are included in Appendix A, Transportation Risk and Cost. OOE also plans to conduct further studies of transportation risk and cost to provide additional clarification of the potential impacts of spent fuel transportation activities within the waste management system. The results of these further studies are not, however, anticipated to be significantly different than the results of this study. 



\subsection{INTEGRATED FEDERAL WASTE MANAGEMENT SYSTEM}

If the MRS facility is to be integrated within the waste management system, siting of the MRS facility must take into account various characteristics of the rest of the system. This section provides a description of the integrated waste management system and the role of an MRS facility within this system, based primarily on information provided in Reference 1. A discussion of the waste system logistics considerations relevant to MRS facility siting is included to provide the bases for the siting region analyses discussed in the subsequent sections of this report.

\subsection{BACKGROUND}

The waste management system consists of all functions and operations required for the safe management and disposal of the spent nuclear fuel discharged from reactors and any subsidiary high-level waste material. These functions and operations include all storage, transportation, and packaging of the spent nuclear fuel prior to its ultimate disposal. (If the spent fuel is reprocessed to extract the remaining usable materials, the wastes resulting from the reprocessing step would also be included. However, there is currently no reprocessing of civilian spent nuclear fuel in the U.S., and no plans exist for reprocessing in the near future.)

The NWPA requires DOE to site, license, and operate repositories for the disposal of spent nuclear fuel and high-level radioactive waste resulting from civilian nuclear activities in the U.S. These DOE responsibilities are to be carried out in a manner that "will provide a reasonable assurance that the public and the environment will be adequately protected..." The utilities that operate nuclear power plants are responsible for the management and storage of the spent nuclear fuel until it is received by the Federal government for disposal.

Since the passage of the NWPA, DOE has performed studies of alternative concepts for achieving monitored retrievable storage, and has selected two concepts for conceptual design and engineering. (2) In addition, DOE has been considering how best to integrate MRS facilities into the waste management 
system. In the course of these studies, DOE has recognized that MRS facilities can be beneficially included as an integral part of the waste management system.

In its role as an integral part of the waste management system, the MRS facility will 1) receive spent fuel from most or possibly all reactors, 2) consolidate and package the fuel, and 3), if necessary, store fuel temporarily pending shipment to the repository. Such an integral role does not preclude other possible roles for MRS facilities. The current view of the integrated waste management system is described below.

\subsection{OVERVIEW OF THE INTEGRATED WASTE MANAGEMENT SYSTEM}

The purpose of the waste management system is to receive spent fuel and high-level radioactive waste from the operation of commercial nuclear power reactors and to dispose of that material in a manner that protects the health and safety of the public and maintains the quality of the environment. To do this, the system must provide and manage the following functions:

- accept commercially produced spent nuclear fuel and high-level radioactive waste;

- transport accepted waste materials to disposal sites, including intermediate facilities designed for storage and packaging;

- prepare, package and store the waste as needed before permanent disposal;

- provide permanent disposal for all waste accepted into the system. The principal components of the integrated waste management system are shown in Figure 4.1.(1) These components include the waste generators (primarily commercial power reactors discharging spent fuel), repositories, MRS facilities, and the transportation system that connects the other system components. Each of these components affects the ability of the system to carry out the primary waste management functions listed above.

The integrated system will be designed to receive and ship a variety of spent fuel and high-level waste forms and to prepare them for ultimate disposal in the repository. Most spent fuel will be shipped directly from reactors to an MRS facility. 

Spent fuel will be consolidated and canistered at the MRS facility for shipment to the repository. In addition, the MRS facility will be able to provide safe storage for all wastes awaiting shipment to the repository. The spent fuel canisters will not remain at the MRS facility any longer than necessary; however, the canisters could be stored for long periods if unforeseen problems develop at the repository or if longer storage would improve repository operations. Multiple shipping casks can be used in each shipment from the MRS facility to the repository to reduce the number and potential impact of these shipments.

Ultimate disposal of all waste accepted into the system will be in a geologic repository. As directed by the NWPA, DOE is planning for two such repositories.

DOE will begin receiving commercial spent fuel and other high-level wastes when the MRS facility begins operating--prior to 1998 as presently envisioned. Shipments out of the MRS facility will begin when repository operations commence--currently scheduled for 1998 for the first repository and 2006 for the second.

\subsection{WASTE MANAGEMENT SYSTEM LOGISTICS CONSIDERATIONS}

Three logistics considerations important to this study are 1) facility locations, 2) MRS facility operations, and 3) transportation system operations. Many decisions about the operation of the waste management system will be made after ongoing or planned investigations are completed. As a result, there are a number of possible alternatives for operation of the waste management system. Other considerations (e.g., the order and schedule for spent fuel receipts), although they may affect the operation of the system, do not affect total shipment miles as a function of MRS facility location and are not discussed here.

\subsubsection{Locations of Facilities}

The locations of the reactors (sources of spent fuel) shipping to an MRS facility and the location of the repository (final spent fuel destination) are important variables in the analysis reported here. While the reactor locations 
are known, assumptions must be made about which reactors ship fuel to an MRS facility. The location of the first repository will be selected in the future from among nine sites under consideration.

The majority of the nuclear power plants and, therefore, of the spent fuel to be received into the waste management system are located in the eastern and midwestern parts of the U.S. As an integral part of the waste management system, the MRS facility would receive all of the spent fuel from these plants. The remaining power plants and their fuel are located in the far western part of the country. Spent fuel from these western plants could be accommodated in one of the three ways:

1. ship all fuel, from both eastern and western sources, to one MRS facility;

2. ship spent fuel generated in the west to a separate but similar type of MRS facility (of smaller capacity) located centrally with respect to the western nuclear power plants; or

3. ship spent fuel generated in the west directly to a small-capacity packaging facility at the first operational repository.

The choice of one of these three options will depend on several factors including economics, the location of the first repository, and the repository waste package and associated shipping cask designs. In the meantime, MRS siting analyses must consider both receiving and not receiving the western spent fuel at the MRS facility. (a)

DOE is currently investigating possible sites for the first repository and has published draft environmental assessments (EAs) on nine potentially acceptable sites. (3) After considering public comments on the draft EAs, five of the sites will be nominated as suitable for characterization, and at least three will be recommended as candidate sites for the first repository. Following further characterization activities, one of the sites will be recommended for

(a) Actually, receiving or not receiving western spent fuel has little effect on the preferred MRS siting location--see Appendix D. 
the first repository. The location of the first repository will affect transportation operations required to move the spent fuel from the MRS facility to the repository.

\subsubsection{MRS Facility Operations}

The MRS facility is intended to receive and handle up to the maximum spent fuel destined for disposal at the first repository, a total of 70,000 MTU. However, the operation of the MRS facility could be extended to include the receipt and handing of additional spent fuel. The total amount of fuel handled at the MRS facility will affect the number and total size of the spent fuel shipments from the reactors to the MRS facility. (The timing of these shipments, although important to other aspects of the waste management system, does not affect MRS facility siting decisions.)

Spent fuel rod consolidation, a process of disassembling spent fuel assemblies and repackaging the fuel rods to reduce their volume, is planned to be used at the MRS facility to prepare the fuel for disposal at the repository. The extent of the volume reduction to be achieved is yet to be determined and will be based on a number of technical and economic factors. The amount of volume reduction will influence the number of shipments required from the MRS facility to the repository (and, consequently, the balance between shipments from the reactors to the MRS facility and shipments from the MRS facility to the repository).

\subsubsection{Transportation Operations}

Spent fuel shipping cask designs can be developed that will provide increased cask capacities prior to the start of MRS facjlity operation. Cask capacities have a strong influence on the number of spent fuel shipments that will be required within the waste management system, both to and from the MRS facility.

Whether spent fuel shipments by rail will be made in single-cask units or multiple-cask units (truck shipments will always be in single-cask units) will depend on a number of factors, including economics and other considerations 
that have not been fully examined at this time. Multiple-cask rail units, where used, would reduce the number of shipments required to move specified quantities of spent fuel.

Because the capacities of spent fuel shipping casks depend on the mode of transportation, decisions about transportation modes to be used will affect the number of spent fuel shipments required. Some of the nuclear power reactors in the U.S. lack proper facilities to handle the large rail casks and are therefore constrained to shipment only by truck. (4) Because of this, truck shipments will be required from some reactors to the MRS facility. Shipment by barge was not considered in this study. Therefore, for this study, rail shipments were assumed whenever possible, both to and from the MRS facility, with truck shipments used where necessary from specific reactors.

\section{REFERENCES}

1. Office of Civilian Radioactive Waste Management. 1985. The Integrated System for the Management of Spent Nuclear Fuel and High-Level Radioactive Waste, U.S. Department of Energy, Washington, D.C. (February 11, 1985).

2. DOE. 1984. Selection of Concepts for Monitored Retrievable Storage of Spent Nuclear Fuel and High-Level Radioactive Waste, D0E/RL-84-2. U.S. Department of Energy, Richland Operations Office, Richland, Washington.

3. "Nuclear Waste Policy Act of 1982; Availability of Oraft Environmental Assessments for Proposed Site Nominations and Announcement of Public Information Meetings and Hearings," Federal Register, Vol. 49, No. 246, U.S. Department of Energy, Washington, D.C., December 20, 1984.

4. Daling, P. M., et al. 1985. Spent Nuclear Fuel Shipping Cask Handling Capabilities of Commercial Light Water Reactors, PNL-5384. Pacific Northwest Laboratory, Richland, Washington. 


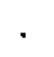




\subsection{ANALYTICAL APPROACH AND METHODS}

Travel distance contours were calculated and mapped for a range of potential systems logistics combinations. These contours were overlapped to find the region common to the range of logistics combinations consistent with currently considered waste system alternatives. This section describes the steps and assumptions used in this process. Discussions of the analytical approach, the assumptions and methods used for the analyses and uncertainties associated with the analyses are included. The section concludes with an example illustrating how the siting analyses were performed.

\subsection{ANALYTICAL APPROACH}

As discussed in Section 4, a number of decisions that will affect the logistics of the Federal waste management systern are yet to be made. Because the logistics of the waste management system will affect the number and geographic distribution of spent fuel shipments within the system, a number of possible combinations of logistics factors was examined in this study.

For each of these combinations of logistics factors, calculations were made to identify contours of total shipment miles. For each case, contours were established for total shipment miles $10 \%$ and $20 \%$ greater than the lowest achievable total with an MRS facility included in the system. The region identified by the contours varied in location, size, and shape depending on the specific combination of logistics factors considered. The analyses included all spent fuel shipments from the nuclear power reactors to the MRS facility as well as shipments from the MRS facility to a geologic repository.

Following this initial step, individual regions that were identified for each combination of logistics factors were compared. These individual regions intersected, or overlapped, to define a circular and somewhat smaller region. Location of an MRS facility within this smaller composite region will limit total shipment miles to an amount within $20 \%$ of the lowest achievable total, regardless of which of the previously identified combination of logistics factors is considered. Locating an MRS facility within this latter region, which 
is referred to as the "preferred siting region" in this report, is thus anticipated to reduce total shipment miles within the waste management system regardless of decisions ultimately reached regarding waste system logistics.

Appropriate combinations of logistics factors were analyzed to determine the greatest possible extent of the sensitivities to individual factors (i.e., the extremes of their effects). The logistics factors relevant to this study were introduced in Section 4.3 of this report. These factors, and realistic possible ranges for each of them, are briefly described below and are summarized in Table 5.1 .

\subsubsection{Repository Locations}

DOE is currently investigating nine possible sites for the first repository. (1) Additional sites will be considered for a second repository. The

TABLE 5.1. Ranges of Waste System Logistics Factors Used for Siting Analysis

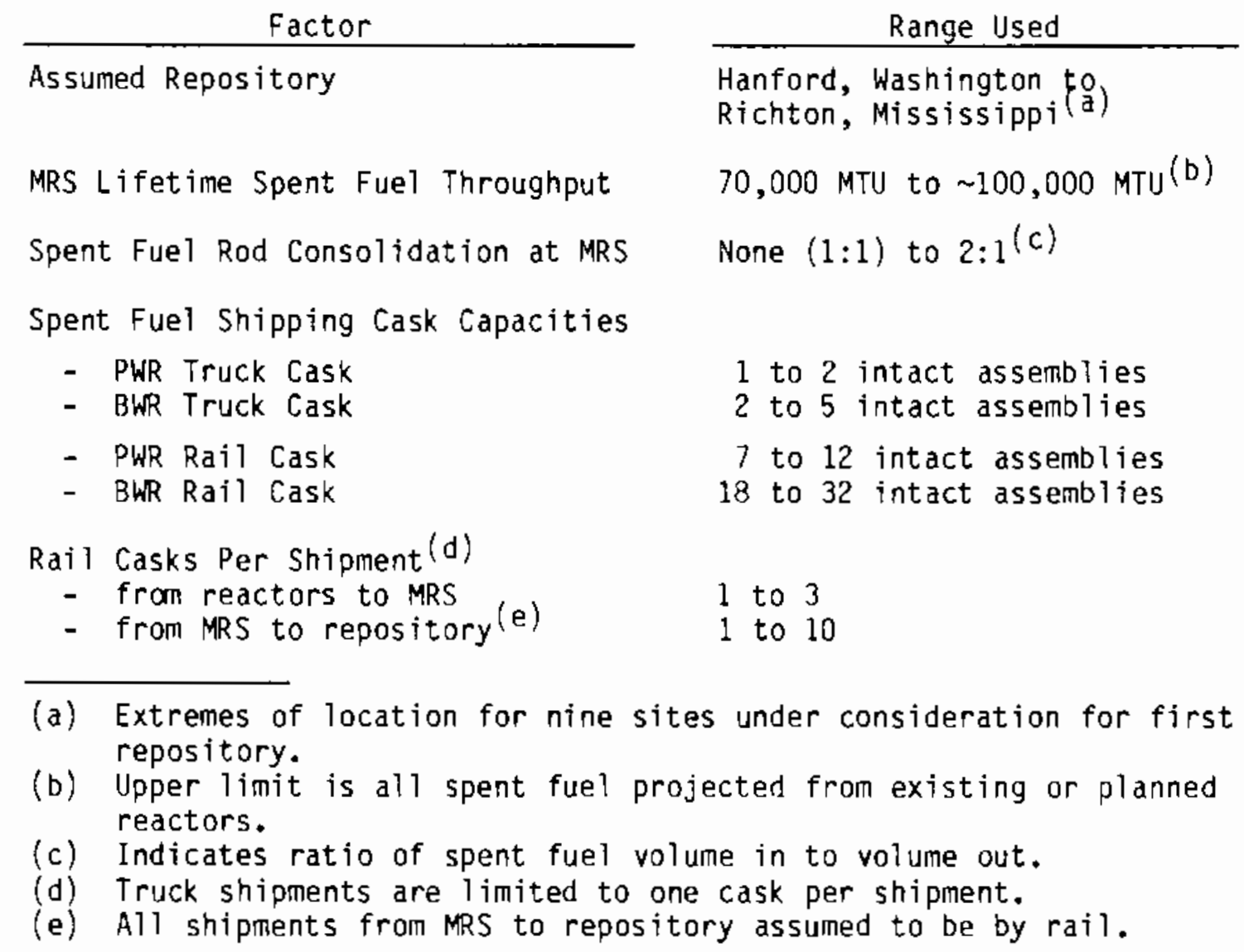


locations of the repositories will affect transportation operations required to move the spent fuel from the MRS facility to the repositories.

To ensure the applicability of the preferred MRS region selected, regardless of which repository sites are chosen, the analyses conducted for this study examined the impacts of possible repository locations on the selection of the preferred siting region. All of the prospective sites for the first repository lie roughly along a curved line extending from the Hanford site in Washington on the northwest end to the Richton site in Mississippi on the southeastern end. These two sites, representing the extremes of the possible first repository locations, were used predominantly to examine the sensitivity of the preferred MRS siting region to repository location.

\subsubsection{Lifetime Spent Fuel Throughput of the MRS Facility}

The current estimate of the spent fuel handling capacity of the MRS facility over its operating lifetime is 70,000 MTU. However, the operation of the MRS facility could be extended to handle greater quantities of spent fuel. In addition, the question of whether spent fuel from reactors in the west coast states will be shipped to the MRS facility or will be handled in some other manner is yet to be decided. Therefore, the impacts of these possible variations in the lifetime handling capacity of the MRS facility were evaluated in the siting region analyses. Further discussion of these factors is included in Section 5.2 which is entitied Basic Study Assumptions.

\subsubsection{Magnitude of the Volume Reduction from Spent Fuel Rod Consolidation}

Spent fuel is to be consolidated at the MRS facility as part of the preparation of the fuel for disposal at the repository. A number of technical and economic factors remain to be determined before the volume reduction to be obtained by spent fuel rod consolidation at the MRS facility can be established. Therefore, to determine the affects of various levels of rod consolidation on the preferred siting region, different degrees of volume reduction were analyzed. The degree of volume reduction for these analyses ranged from no volume reduction (i.e., no rod consolidation) to a reduction of the incoming spent fuel volume by one-half (the approximate expected achievable limit) before shipment.(2) 
For this study, the rod consolidation ratio at the MRS facility was divided into the number of outbound shipments that would be required for intact spent fuel assemblies to obtain the required number of consolidated fuel shipments to the repository. Details regarding the size and shape of the canisters containing the spent fuel rods were not considered. Furthermore, although the disposal of the fuel assembly hardware remaining after rod consolidation would reduce the effective ratio of incoming to outgoing shipments somewhat, these effects were not specifically addressed. Taking into account the disposal of the fuel assembly hardware, an effective consolidation ratio of 2:1 may not be realistically achievable. However, the results obtained using this ratio are still useful in determining the limits of the effects of rod consolidation on total shipment miles within the waste management system.

\subsubsection{Spent Fuel Shipping Cask Capacities}

The capacities of the spent fuel shipping casks currently being used in the U.S. may not be representative of those that will be available at the time the MRS facility is receiving spent fuel for disposal. Therefore, a range of shipping cask capacities was considered in this study, from the capacities of the currently available casks to those of DOE generic casks. (3) This range of cask capacities, while not covering all possible options for deployment of future casks, provides a sufficient basis for determining the effects of cask capacity changes on shipment requirements.

\subsubsection{Use of Single-Cask or Multiple-Cask Shipments}

Whether or not spent fuel shipments will be made in single-cask or multiple-cask units will be depend on a number of factors, including cost and other considerations, which have not been fully examined at this time. Therefore, the possible effects of grouping casks into multiple-cask shipments on total shipment miles and, thus, on the preferred siting region were evaluated. Variations considered included the use of multiple-cask shipments both to and from the MRS facility, and the use of multiple-cask shipments only for those shipments from the MRS facility to the repository. 


\subsubsection{Iransportation Modes to be Used}

Because the capacities of the spent fuel shipping casks depend on the mode of transportation, changes in the transportation modes would result in corresponding changes in the shipment miles required to transport a given amount of spent fuel. For this study, it was generally assumed that spent fuel transportation would be by rail whenever possible, with truck shipments used where necessary from reactors that are unable to handle rail casks. (4)

\subsection{BASIC STUDY ASSUMPTIONS}

Two basic assumptions were used in carrying out the this study. These assumptions are discussed in the following paragraphs.

Assumption 1: The inventory of spent fuel to be received at the MRS facility is the oldest spent fuel available, up to the total MRS lifetime throughput.

Because the conditions and schedules for acceptance of spent fuel from the utilities have not yet been determined and because the time of receipt does not affect the shipment miles, no specific at-reactor holding periods were assumed for spent fuel prior to its receipt by DOE. Instead, the spent fuel assemblies were assumed to be received and handled at the MRS facility in the order they were discharged from the reactor cores (i.e., the oldest spent fuel was assumed to be received first). Fuel was assumed to be accepted up to the total lifetime throughput of the MRS facility. Two variations on the quantity to be handled were included:

1. In the first variation, the first 70,000 MTU of spent fuel projected to be discharged by the commercial power reactors was assumed to be handled over the operating lifetime of the MRS facility.

2. In the second variation, all of the spent fuel projected to be discharged during the operating lifetime of the currently planned or operating reactors was assumed to be handled at the MRS facility. This fuel totals approximately 100,000 MTU. 
Assumption 2: Actual travel distances that would be realized in transporting the spent fuel can be approximated, within the accuracy required for these analyses, by using adjusted great-circie distances.

The calculation of actual travel distances for transporting spent fuel involves the selection of specific transportation routes for each shipment. The selection of specific transportation routes involves trade-offs in addition to reducing total shipment miles and is dependent on the results of current or planned studies. Therefore, for the purposes of identifying a preferred MRS siting region, the distance calculations have been performed using great-circle distances, with appropriate adjustments to approximate actual travel distances.

A great-circle distance represents the shortest possible distance between two points on the surface of a sphere (in this case, two locations on the surface of the Earth). The calculation of these distances is a standard procedure used commonly for navigational purposes.

Because great-circle distances represent the most direct route theoretically possible between two points, they tend to under-estimate actual travel distances over land routes, where such direct routes are not realistic. Therefore, the great-circle distances have been adjusted upward to account for the average increases in actual travel distances over the calculated great-circle distances. The adjustment factors used are 1.15 for truck shipments and 1.33 for rail shipments. (a) The expected accuracy of this method is discussed in Section 5.4 entitled Analytical Uncertainties.

\subsection{ANALYTICAL METHODS}

The analyses performed to identify the preferred MRS siting region consisted primarily of three steps:

(a) Memorandum from S. M. Short to M. R. Shay (both PNL), Development of an Algorithm to Estimate Spent Fuel Truck Transportation Distances, February 25, 1985. 
Step 1. Identification of the specific quantities and corresponding source locations of the spent fuel to be received at the MRS facility. This step provides the necessary basis for the following steps.

Step 2. Identification of the minimum achievable shipment mile total and corresponding distance contours. This step identifies the region within which locating an MRS facility would keep total shipment miles within a given percentage of the achievable minimum.

Step 3. Calculation of total shipment miles by shipment category (e.g., to versus from the MRS facility, truck versus rail shipments).

The last two steps were repeated for each separate combination of waste management system logistics factors (including repository location, shipping cask capacities, etc.) that was examined.

These three analytical steps are described briefly below. Further details regarding the analytical methods and tools are included in Appendix $B$.

\subsubsection{Identification of the Spent Fuel (Step 1)}

The region within which locating an MRS facility would keep total shipment miles throughout the waste management system within some percentage of the minimum achievable total is dependent on the spent fuel that is to be received. The spent fuel information used for the siting analyses and the source of this information are presented and discussed in Appendix $C$.

With the exception of the quantities of spent fuel that are to be received from each reactor, the required information can be drawn directly from the basic source. ${ }^{(5)}$ The spent fuel quantities to be received from each reactor were derived from the basic source information by simulating the receipt of the spent fuel into the system strictly on the basis of oldest fuel first, with spent fuel being received until the maximum lifetime throughput of the MRS facility was reached.

Four major cases were developed to provide the information needed for the the calculation of travel distances and contours, as follows: 
Case 1. 70,000 MTU of spent fuel from all reactors,

Case 2. 70,000 MTU of spent fuel excluding reactors in the West Coast States,

Case 3. A11 spent fuel (about 100,000 MTU) from all reactors, and

Case 4. All spent fuel excluding that from the West Coast reactors (a total of about 91,000 MTU).

The last two cases correspond to an extended lifetime MRS throughput. Detailed listings of the projected spent fuel receipts from each reactor for each of these four cases are presented in Section C.2 of Appendix C.

\subsubsection{Identification of Minimum Shipment Miles Location} and Trave 1 Distance Contours (Step 2)

The spent fuel information is used to calculate the number of spent fuel shipments required from each reactor. Using these shipment requirements, and the particular combination of logistics factors under consideration, the MRS location which would result in the minimum achievable total shipment miles and the corresponding travel distance contours can be identified.

To identify the MRS location that would result in the minimum achievable total shipment miles, a geographical grid is defined and total shipment miles are calculated for an assumed MRS facility at each point on the grid (i.e., each intersection of the grid lines). Once the total shipment miles have been calculated for each point on the grid, contours of the shipment mile totals can be drawn by interpolating (i.e., estimating values) between the points on the grid. To provide increased accuracy in identifying specific locations, the grid can be redefined to increase the number of grid lines or to reduce the area included.

Increases of $10 \%$ and $20 \%$ over the minimum achievable shipment mile total were selected for establishing distance contours. For all of the combinations of logistics factors, the region bounded by the $20 \%$ contour is large enough to provide a substantial number of potential MRS-site choices, while providing substantial reductions in total shipment miles when compared to locating the MRS facility in some other area. Using two contours in combination provides an 
indication of the rate of change in total shipment miles as the location is moved away from the point providing the minimum achievable total for the purposes of siting an MRS, any location within the $20 \%$ contour can be considered equivalent to any other, because the anticipated errors in the spent fuel information and the calculations are of a comparable magnitude.

The analytical tools that were used to locate the point corresponding to the minimum achievable shipment mile total and to draw the associated contours are described in Appendix B.

\subsubsection{Calculation of Total Shipment Miles (Step 3)}

Following the identification of the location yielding the minimum achievable shipment miles for the combination of waste system logistics factors being examined, the shipment mile totals that would result can be calculated.

Total shipment miles are calculated by suming the shipments from each reactor to the MRS facility and the shipments from the MRS facility to the repository. In addition, subtotals can be calculated for each combination of travel mode (i.e., truck versus rail shipments) and reactor fuel type (i.e., PWR versus $B W R$ ).

\subsection{ANALYTICAL UNCERTAINTIES}

As with any analysis, there are several areas of uncertainty associated with the analyses performed to identify the preferred region for siting an MRS facility. These areas of uncertainty and their probable effects on the results of the analyses are discussed below.

The spent fuel information used for the siting region analyses, summarized in Appendix $C$, consists primarily of projections of future spent fuel discharges and inventories that are based on assumptions about the future operation of the nuclear power reactors. (5) Information is currently availabie for actual spent fuel discharges for the period through the end of 1983, covering a total inventory of about 10,000 MTU of spent fuel. Thus, the majority of the spent fuel information used for the MRS siting region analyses is based on projections. The accuracy of these projections will not be known for some time. Significant changes in reactor operations in specific regions of the 
country could skew the results slightly because of the resulting changes in the number of shipments to the MRS facility from one direction. However, even fairly substantial changes in reactor operations would not cause significant changes in the location or size of the preferred siting region.

As discussed previously, adjusted great-circle distances are used in this study to calculate shipment miles. These adjusted great-circle distances are expected to be typically within $2 \%$ to $3 \%$ of the actual route-specific distances that would be encountered. (a) This is believed to provide sufficient accuracy to meet the purpose and objectives of this study.

\subsection{EXAMPLE ILLUSTRATION OF SITING ANALYSES PERFORMED}

An example illustration of the siting analyses performed in this study is provided below. This example is for a single combination of waste management system logistics factors. Changes in these results with changes in the logistics factors are discussed in Sections 6 and 7 .

The waste system logistics factors considered in this example are shown in Table 5.2. The spent fuel information used to calculate travel distances and the number of shipments that would be required over the operating lifetime of the MRS facility is presented in Table C.2 of Appendix C.

Shipments to the MRS facility from each reactor can be calculated by dividing the number of spent fuel assemblies by the appropriate shipping cask capacity for the type of fuel (i.e., PWR or BWR) and the shipping mode, and rounding up to the next whole number of shipments. The shipments for each facility can then be summed to find the total number of shipments to the MRS facility. The required number of shipments for each fuel type from the MRS facility to the repository is calculated by dividing the total number of assemblies for each fuel type by the appropriate rail cask capacity, dividing that result by the number of casks per shipment and rounding the result up to the next whole number. The shipments for the two types of fuel can then be summed to find the total number of shipments from the MRS facility to the repository.

(a) Memorandum from S. M. Short to M. R. Shay (both PNL), Development of an Algorithm to Estimate Spent Fuel Truck Transportation Distances, February 25, 1985 . 
TABLE 5.2. Waste System Logistics Factors Used for Example Illustration of Siting Analyses

Factor

MRS Lifetime Spent Fuel Receipts

Spent Fuel Shipping Cask Capacities(a)

- PWR Truck Cask

- BWR Truck Cask

- PWR Rail Cask

- BWR Rail Cask

Casks per Shipment

- from Reactors to MRS

- from MRS to Repository(b)

Spent Fuel Rod Consolidation at MRS

Assumed Repository Location;

Hanford, Washington (BWIP) (d)

- latitude

- longitude

\section{Information Used or Assumed}

70,000 MTU

1 assembly

2 assemblies

7 assemblies

18 assemblies
1

3

46.55 degrees North

( 45 degrees, 33 minutes $N$ )

119.66 degrees West

(119 degrees, 40 minutes $W$ )

(a) Capacities shown are for intact spent fuel assemblies. For consolidated fuel, the capacity is multiplied by the consolidation factor to find the equivalent capacity for consolidated fuel rods.

(b) All shipments from the MRS facility to the repository are assumed to be by rail.

(c) Indicates ratio of spent fuel volume in to volume out. In this case, every three assemblies coming in to the MRS facility would be reduced to the equivalent volume of two assemblies going out (including fuel assembly hardware in the outbound shipments).

(c) BWIP is an acronym for Basalt Waste Isolation Project, the of $i$ cial name of the repository project at Hanford.

Calculation of the travel distances and contours is performed as described in Appendix B. Figure 5.1 shows the region identified for the example case as including all locations with total shipment miles within $20 \%$ of the achievable minimum. The location calculated to have the minimum total shipment miles, approximately located at 37.9 degrees North latitude and 82.3 degrees West longitude, is also shown on the figure. The figure reveals that the travel 


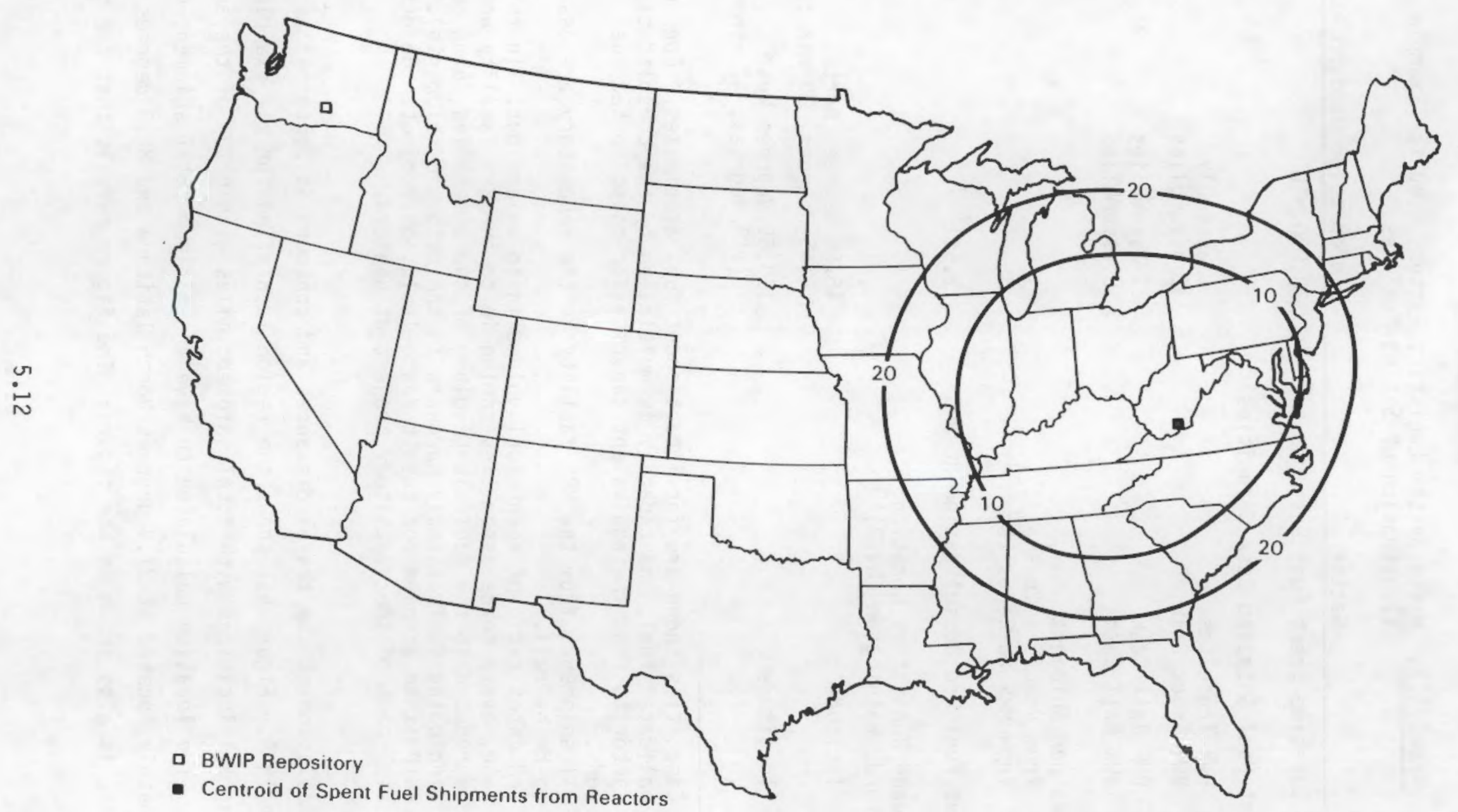

FIGURE 5.1. Region which Minimizes Total Shipment Miles: Example Case(a)

(a) Based on waste system logistics described in Table 5.2. 
distance contours are not circular, but rather are elongated in the direction of the repository location chosen for analysis. In addition, the distance between the minimum point and the $10 \%$ contour is greater than the distance between the $10 \%$ and $20 \%$ contours. If the calculated total shipment miles at any point are used to convert the map to a three-dimensional representation of shipment miles as a function of location, a bowl-shaped depression results with the travel distance contours in the lowest area. The slope of the bowl increases with movement away from the center (i.e., the minimum point). In addition, the shape of the bowl is not symmetrical. Instead, the slope increases most rapidly in the direction opposite the repository.

Table 5.3 presents a summary by category of the shipment mile totals for the example case. The same information is shown graphically in figure 5.2.

The type of information presented here for the example case was developed for each of the combinations of waste system logistics factors evaluated in this study. This type of information was used to to determine the sensitivity of the results to changes in logistics factors as presented in Sections 6 and 7.

\section{REFERENCES}

1. "Nuclear Waste Policy Act of 1982; Availability of Draft Environmental Assessments for Proposed Site Nominations and Announcement of Public Information Meetings and Hearings," Federal Register, Vol. 49, No. 246, U.S. Department of Energy, Washington, D.C., (December 20, 1984).

2. Bailey, W. J. 1985. Status of Rod Consolidation, PNL-5122. Pacific Northwest Laboratory, Richland, Washington.

3. Wilmot, E. L., M. M. Madsen, J. W. Cashwell, and D. S. Joy. 1983. A Preliminary Analysis of the Cost and Risk of Transporting Nuclear Waste to Potential Candidate Repository Sites, SAND83-0867, Sandia National Laboratories, Albuquerque, New Mexico.

4. Daling, P. M. et al. 1985. Spent Nuclear Fuel Shipping Cask Handling Capabilities of Commercial Light Water Reactors, PNL-5384, Pacific Northwest Laboratory, Richland, Washington.

5. Heeb, C. M., R. A. Libby, and G. M. Holter. 1985. Reactor-Specific Spent Fuel Discharge Projections: 1984 to 2020, PNL-5396. Pacific Northwest Laboratory, Richland, Washington. 
TABLE 5.3. Summary of Shipment Mile Totals Calculated for the Example Case (a)

\begin{tabular}{|c|c|c|c|c|c|}
\hline \multirow[b]{2}{*}{ Item } & \multicolumn{2}{|c|}{ Truck Shipments } & \multicolumn{2}{|c|}{ Rail Shipments } & \multirow[b]{2}{*}{ TOTALS } \\
\hline & PWR & $B W R$ & PWR & BWR & \\
\hline \multicolumn{6}{|l|}{ From Reactors to MRS: } \\
\hline $\begin{array}{l}\text { Spent Fuel Shipped } \\
\text { Assemblies } \\
\text { Metric Tons }\end{array}$ & $\begin{array}{l}34271 \\
14499\end{array}$ & $\begin{array}{r}31771 \\
5697\end{array}$ & $\begin{array}{l}67857 \\
29607\end{array}$ & $\begin{array}{l}112261 \\
20197\end{array}$ & $\begin{array}{r}246160 \\
70000\end{array}$ \\
\hline Number of Shipments & 34271 & 15889 & 9716 & 6255 & 66131 \\
\hline $\begin{array}{l}\text { Average Shipment Distance } \\
\text { (miles) }\end{array}$ & 779 & 728 & 828 & 600 & \\
\hline $\begin{array}{l}\text { Shipment Miles } \\
\text { (millions of miles) }\end{array}$ & 26.7 & 11.6 & 8.05 & 3.76 & 50.1 \\
\hline \multicolumn{6}{|l|}{ From MRS to Repository: } \\
\hline Number of Shipments (b) & -- & -- & 3243 & 1779 & 5022 \\
\hline Shipment Distance (miles) & -- & -- & 2597 & 2597 & 2597 \\
\hline $\begin{array}{l}\text { Shipment Miles } \\
\text { (millions of miles) }\end{array}$ & -- & -- & 8.42 & 4.62 & 13.0 \\
\hline \multicolumn{6}{|l|}{ Overall Totals: } \\
\hline Number of Shipments & 34271 & 15889 & 12959 & 8034 & 71153 \\
\hline $\begin{array}{l}\text { Shipment Miles } \\
\text { (millions of miles) }\end{array}$ & 26.7 & 11.6 & 16.5 & 8.38 & 63.2 \\
\hline & & & Rail & & \\
\hline Overall Summary & Truck & Into MRS & Out of MRS & Total & Totals \\
\hline Number of Shipments & 50160 & 15971 & 5022 & 20993 & 71153 \\
\hline $\begin{array}{l}\text { Shipment Miles } \\
\text { (millions of miles) }\end{array}$ & 38.3 & 11.8 & 13.0 & 24.9 & 63.2 \\
\hline
\end{tabular}

(a) Based on waste system logistics described in Tabie 5.2 .

(b) For this case, each shipment from the MRS facility to the repository consists of three casks loaded with consolidated spent fuel. 

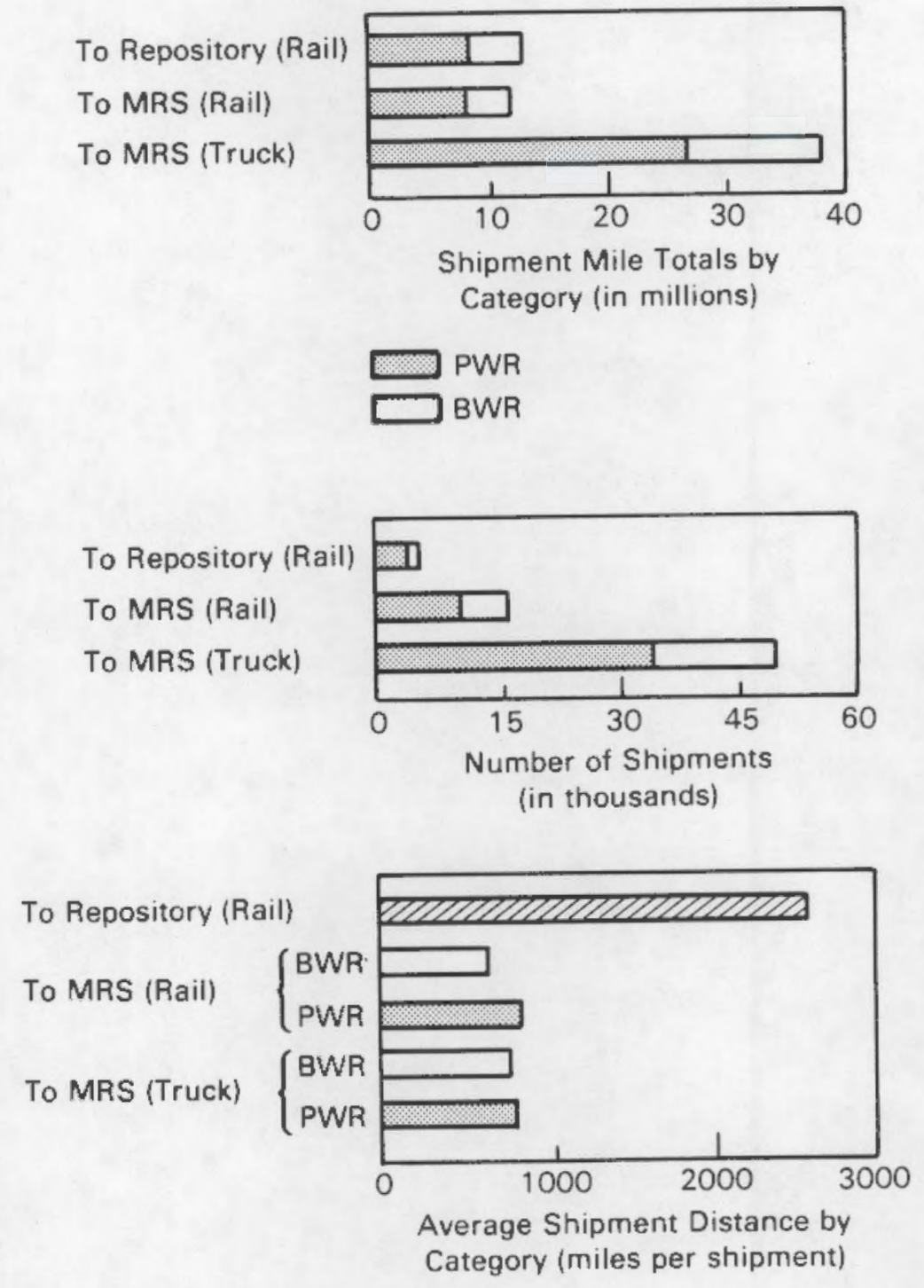

FIGURE 5.2. Summary of Shipment Mije Totals Calculated
for the Example Case(a)

(a) Based on waste system logistics described in Table
5.2 and on summary information included in Table 5.3. 


\subsection{SENSITIVITY OF THE SITING REGION TO WASTE SYSTEM LOGISTICS}

The shape and location of the minimum distance contours are sensitive to changes in waste management system logistics. A discussion of the various sensitivities, assuming a single repository location, is presented in this section to help in understanding the interactions involved. Following that discussion, the sensitivities of the minimum distance contours to changes in repository location are discussed.

\subsection{SENSITIVITIES FOR A SINGLE REPOSITORY LOCATION}

The location of the centroid of the projected spent fuel shipments to the MRS facility provides a useful reference point for discussion of the sensitivity of the siting region. Centroids for each of the four sets of spent fuel information used in this study are shown and discussed in Appendix D, Geographic Distribution of Spent Fuel. These four sets represent the following:

Case 1. 70,000 MTU of spent fuel from all reactors,

Case 2. 70,000 MTU of spent fuel excluding reactors in the west coast States,

Case 3. All spent fuel (about 100,000 MTU) from all reactors, and

Case 4. All spent fuel excluding that from the West Coast reactors.

As shown in Appendix D, the information used in the four cases that were analyzed caused little variation in the location of the centroid. Thus, it is clear that selection of the spent fuel information used (from the four sets considered) will have correspondingly little effect on the location of the preferred siting region. Therefore, although all four cases were analyzed, for the remainder of this section, the discussions will be limited to results obtained using only Case 1--acceptance of the oldest 70,000 metric tons of spent fuel from all reactors in the U.S.

Now that the centroid of the spent fuel into the MRS facility has been defined, a repository can be introduced into the system to receive the spent fuel from the MRS facility. Introducing this factor allows analysis of 
shipments both to and from the MRS facility to identify the potential MRS location that will minimize total shipment miles within the waste management system.

The repository location chosen for purposes of discussion in this subsection is the Basalt Waste Isolation Project (BWIP) at Hanford, Washington. This location was chosen because, of all of the locations being considered for the first repository, it is at the farthest from the reactor spent-fuel shipment centroid identified previously. Because of this dislocation from the centroid, the impacts of changes in waste management system logistics on the preferred siting region will be pronounced and easier to discern.

For the cases considered here, all shipments from the MRS facility to the repository are assumed to be by rail because this is the most likely scenario. Truck casks have much smaller capacities than rail casks and, therefore, the use of truck shipments from the MRS facility to the repository would greatly increase the number of shipments (and, correspondingly, the total shipment miles). This practice would be counter to the objective of minimizing total shipment miles within the waste management system. Truck casks are assumed to be used only for shipments to the MRS facility from reactors that are not capable of handling the large rail casks, as described previously in Section 5.

Figure 6.1 shows the minimum distance contours for a waste management system with BWIP as the repository. In this case, it is assurned that:

- all shipments both to and from the MRS facility are made in singlecask quantities in current-generation spent fuel shipping casks, and

- that there is no spent fuel rod consolidation at the MRS facility. (The current-generation shipping cask capacities are 1 PWR or 2 BWR assemblies per truck cask and 7 PWR or 18 BWR assemblies per rail cask--see Table 5.1.) The contours shown on the figure represent locations that would result in total shipment miles that are $10 \%$ or $20 \%$ greater than the minimum achievable.

The minimum distance contours for this case are located along a line connecting the centroid of the spent fuel shipments with the repository location. The specific location along this line is a function of the ratio between 

the number of shipments to the MRS facility and the number of shipments from the MRS facility to the repository. Examples presented below show the impacts of changes in waste system logistics factors on the ratio between shipments in and shipments out of the MRS facility and, therefore, on the location and shape of the minimum distance contours.

\subsubsection{Spent Fuel Rod Consolidation}

Spent fuel rod consolidation at the MRS to prepare the fuel for repository disposal would reduce the number of shipments from the MRS facility to the repository. The impacts of such reductions are shown in Figures 6.2 and 6.3 for postulated rod consolidation ratios (i.e., spent fuel volume in to volume out) of $1.5: 1$ and $2: 1$, respectively. As the rod consolidation ratio increases, the minimum distance contours move away from the repository location toward the centroid of the incoming spent fuel shipments. The contours also becomes less elongated in the direction of the repository. This change occurs because the influence of the shipments from each of the widely dispersed reactors becomes greater as the relative number of shipments to the repository are reduced.

\subsubsection{Multiple-Cask Shipments}

The figures presented thus far have all been based on single-cask shipments both to and from the MRS facility. Shipments of greater than single-cask quantities, where used, can also reduce the number of shipments and, correspondingly, the total shipment miles.

Figure 6.4 shows the potential impact of using multiple casks for each shipment from the MRS facility to the repository. Shipments to the repository are arbitrarily assumed to be made in three-cask groups. No spent fuel rod consolidation is assumed for this case. The contours identified in the figure indicate that the use of multiple-cask shipments to the repository has the same general effect as spent fuel rod consolidation on shipment miles and, therefore, on the location of the contours.

Multiple-cask shipments on a single truck are not possible because of load weight limits for trucks. However, multiple-cask rail shipments could be made to the MRS facility from those reactors equipped to handle rail casks. The number of casks to be grouped into shipments from reactors is likely to be more 


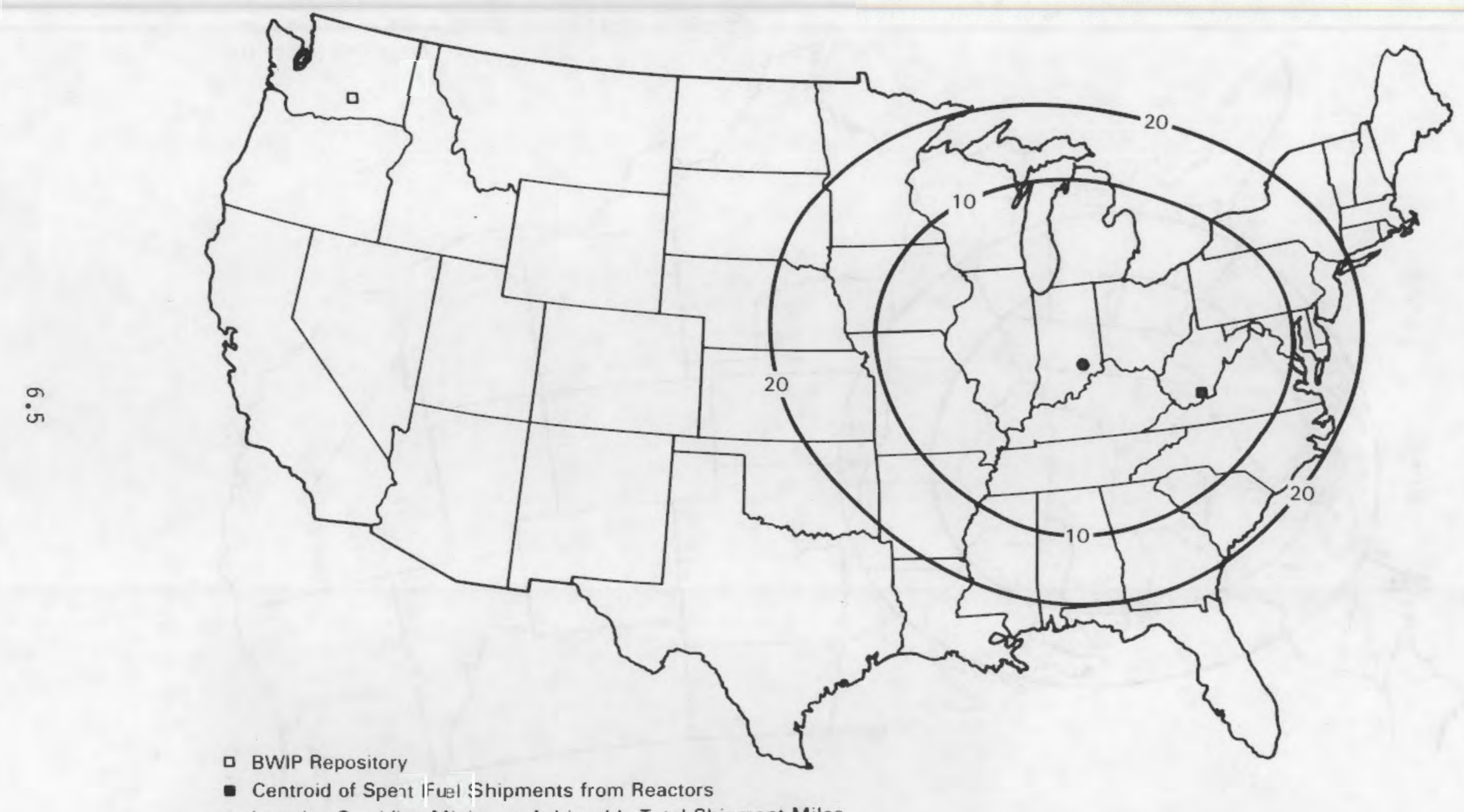

- Centroid of Spent Fuel Shipments from Reactors

- Location Providing Minimum Achievable Total Shipment Miles

FIGURE 6.2. Minimum Distance Contours Assuming Single-Cask Shipments to and from the MRS Facility, Spent Fuel Rod Consolidation $(1.5: 1)$, and the First Repository at BWIP 


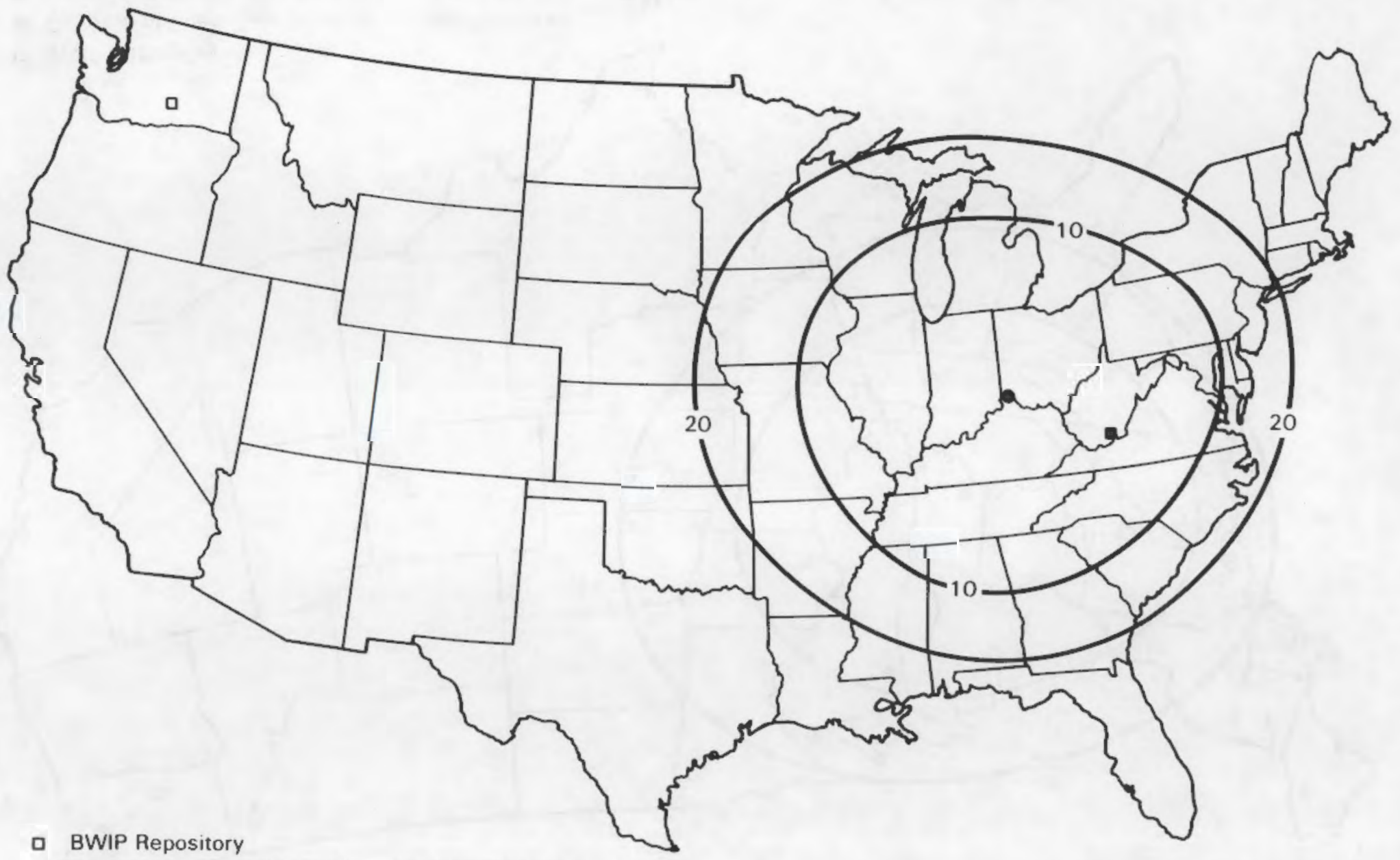

- Centroid of Spent Fuel Shipments from Reactors

- Location Providing Minimum Achievable Total Shipment Miles

FIGURE 6.3. Minimum Distance Contours Assuming Single-Cask Shipments to and from the MRS Facility, Spent Fuel Rod Consolidation (2:1), and the First Repository at BWIP 


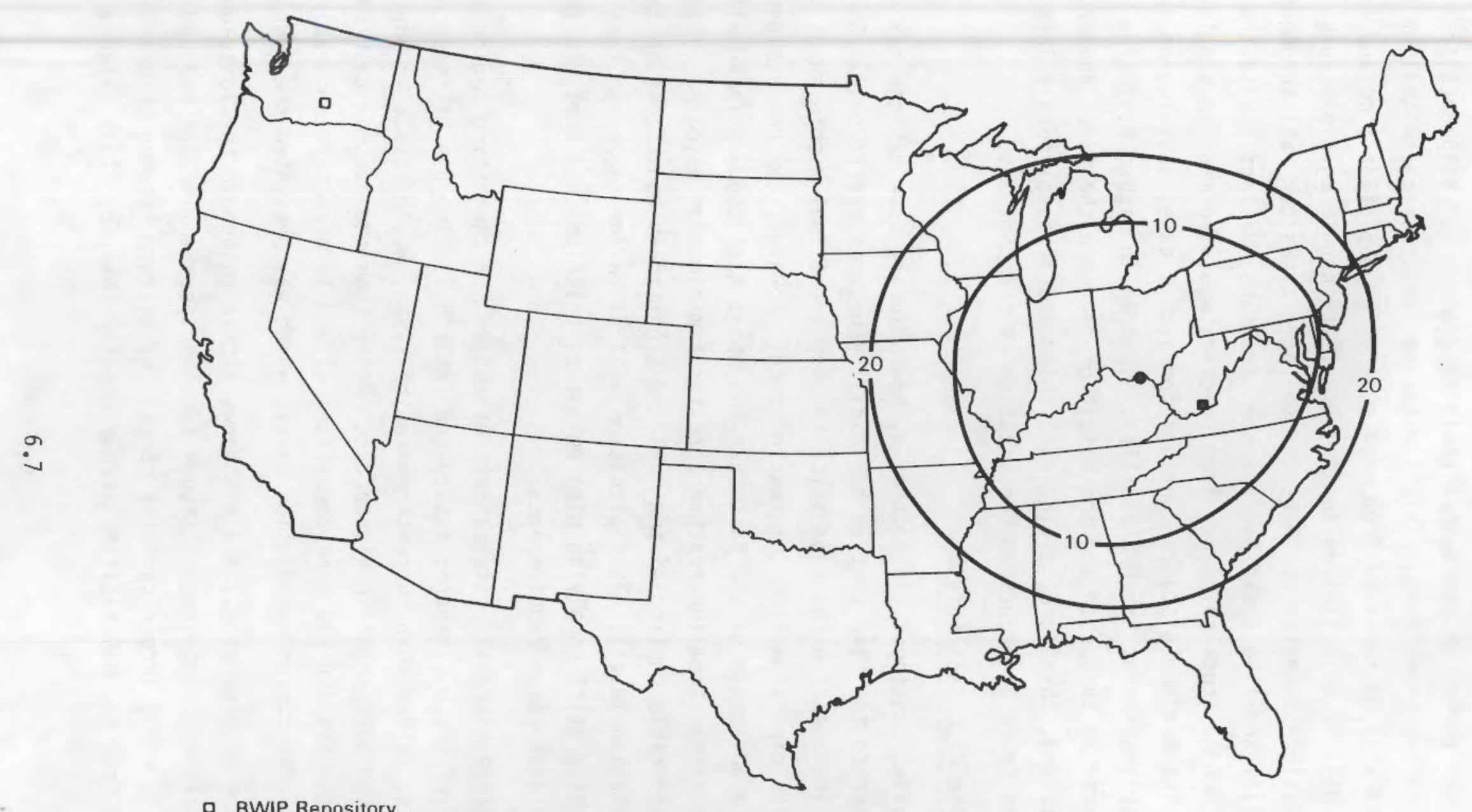

- BWIP Repository

- Centroid of Spent Fuel Shipments from Reactors

- Location Providing Minimum Achievable Total Shipment Miles

FIGURE 6.4. Minimum Distance Contours Assuming Single-Cask Shipments to and 3-Cask Shipments from the MRS Facility, No Spent Fuel Rod Consolidation, and the First Repository at BWIP 
limited than the number of casks that could be grouped for shipments from the MRS facility to the repository. This limitation results because smaller quantities of fuel will be received from each reactor at any given time and because each reactor will be more limited in its ability to handle multiple cask loadings. One possible scenario would be to use three casks per rail shipment to the MRS facility and five casks per shipment from the MRS facility to the repository. Any needed truck shipments from reactors would be made in single-cask quantities. The minimum distance contours for such a case, assuming no spent fuel rod consolidation at the MRS facility, is shown in Figure 6.5. The impacts produced in this case are the result of reducing the total number of rail shipments and, therefore, giving rail shipments proportionately less influence than truck shipments on the location of the contours.

\subsubsection{Shipping Cask Capacities}

As discussed previously in Section 4, new shipping cask designs may be available prior to the time that an MRS facility becomes operational. Current cask designs are based on the capability to ship spent fuel within about 90 to 120 days of its discharge from the reactor core. However, the new designs are likely to take advantage of the fact that the spent fuel to be shipped will have been discharged from the reactor core for a minimum of 5 years, allowing time for considerable cooling of the fuel and significant reductions in the contained radiation levels. This situation will allow for increased cask capacities, while still complying with weight restrictions and heat dissipation and radiation protection requirements.

The possible increased cask capacities chosen for the siting region analyses are those of the DOE generic casks--see Table 5.1. The use of these higher capacity casks, rather than current-generation casks, would result in the minimum distance contours shown in Figure 6.6. Other than the assumed cask capacities, this figure is for the same conditions as and is directly comparable to Figure 6.1 for the current-generation casks, which was presented previously.

Comparison of Figures 6.1 and 6.6 shows little change in the location of the minimum distance contours. Although total shipment miles are reduced considerably by using larger capacity casks, the balance between shipments to and shipments from the MRS facility is not greatly changed. This balance is 


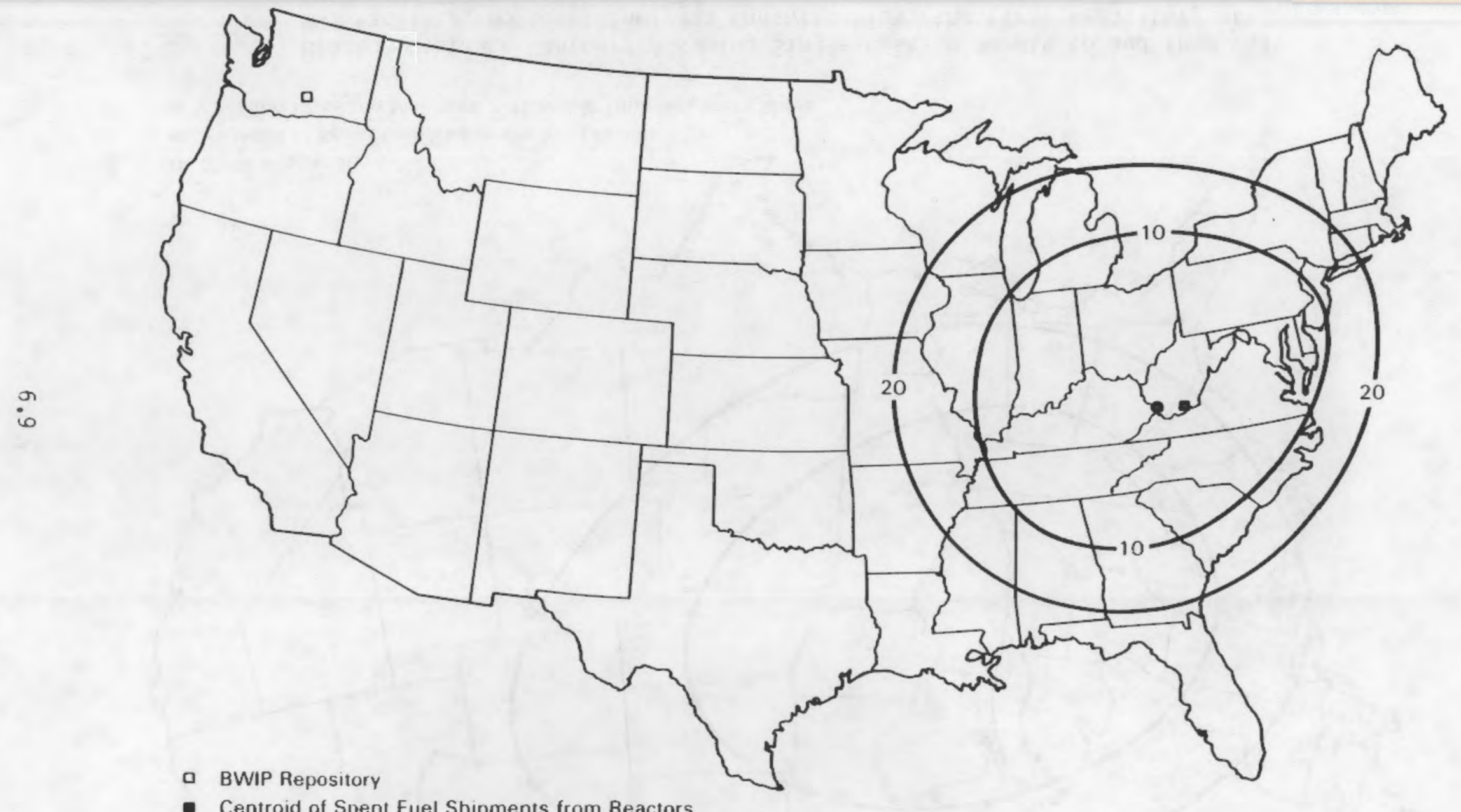

- Centroid of Spent Fuel Shipments from Reactors

- Location Providing Minimum Achievable Total Shipment Miles

FIGURE 6.5. Minimum Distance Contours Assuining Single-Cask Truck or 3-Cask Rail Shipments to the MRS Facility, 5-Cask Shipments from the MRS Facility, No Spent Fuel Rod Consolidation, and the First Repository at BWIP 


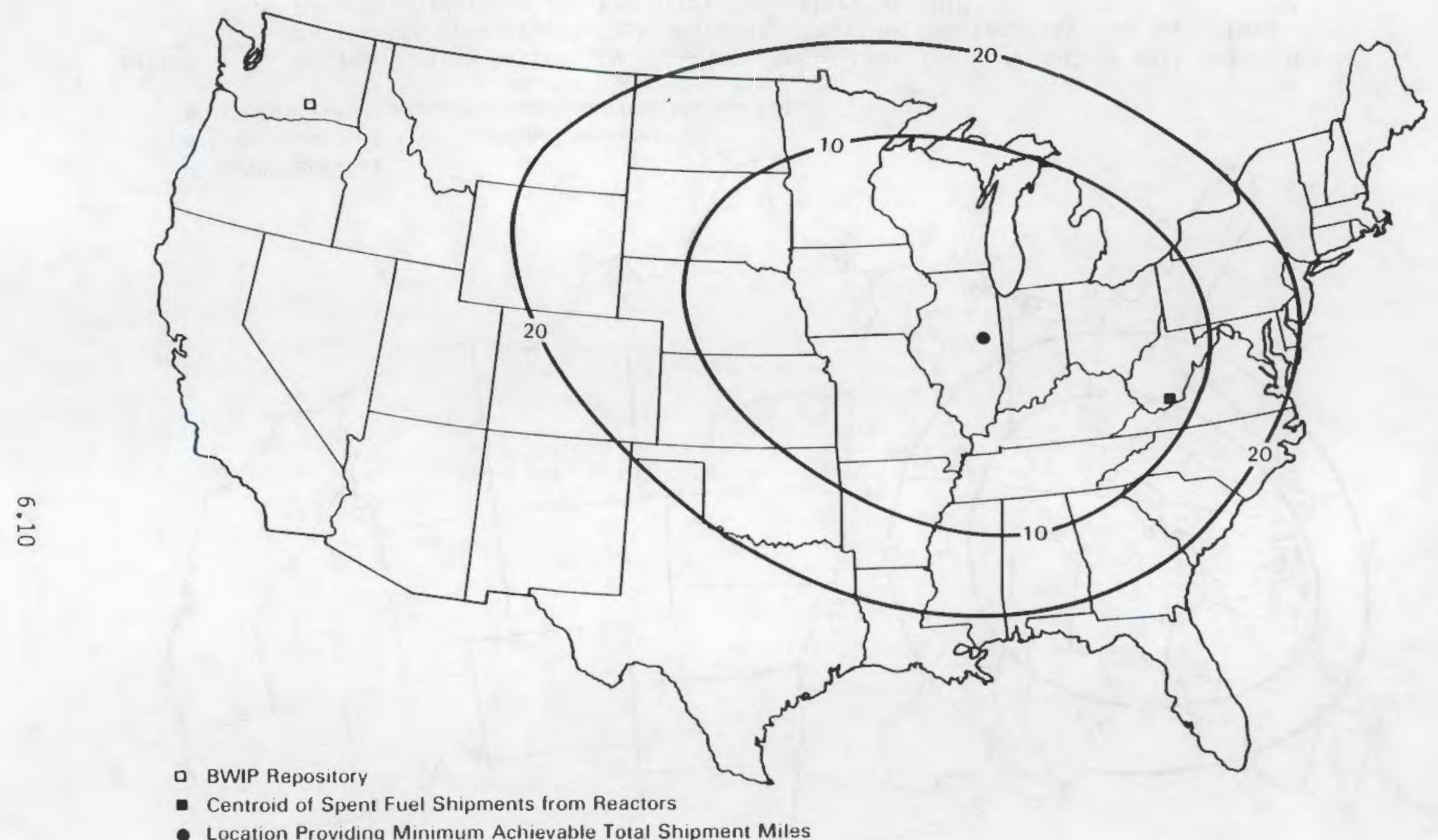

FIGURE 6.6. Minimum Distance Contours Assuming Single-Cask Shipments to and from the MRS Facility, No Spent Fuel, Rod Consolidation, the First Repository at BWIP, and DOE Generic Casks (a)

(a) Capacities are 2 PWR or 5 BWR assemblies per truck cask and 12 PWR or 32 BWR assemblies per rail cask; see Table 5.1 . 
maintained because the larger capacity casks would be used for shipments both to and from the MRS facility, and the ratio of the truck capacities to the rail capacities for both sets of cask designs is very similar. Therefore, although changes in cask capacity would result in proportionate changes in the total shipment miles, significant changes in the location of the minimum distance contours would not be anticipated.

6.1.4 Sensitivities to Combination of Factors

The impacts of the individual factors discussed above can be combined to help understand the impacts of combinations of these factors. In summary, changes in these factors result in changes in the balance between shipments to and shipments from the MRS facility, and correspond to movement of the preferred siting region along a "reference" line between the centroid of the spent fuel from the reactors and the assumed repository location. These movements will also affect the total shipment miles involved, as discussed in Section 7.

\subsection{SENSITIVITIES TO CHANGES IN REPOSITORY LOCATION}

The minimum distance contours are also sensitive to the assumed location of the repository receiving waste from the MRS facility. This subsection shows the sensitivity of the contours to changes in the assumed repository location. An assumed repository location at Richton, Mississippi, is used to provide a contrast to the assumed repository at BWIP, as shown in the previous subsection. (a)

Figure 6.7 shows the minimum distance contours with a repository at Richton, Mississippi, assuming:

- all shipments both to and from the MRS facility in single-cask quantities in current-generation shipping casks, and

- no spent fuel rod consolidation at the MRS facility.

(a) The Richton site is the closest of the nine first-repository sites to the centroid of the spent fuel shipments while BWIP is the furthest from the centroid. Thus, the two sites represent the extremes in location of the sites under consideration for the first repository, and the extremes in MRS-to-repository distance. 


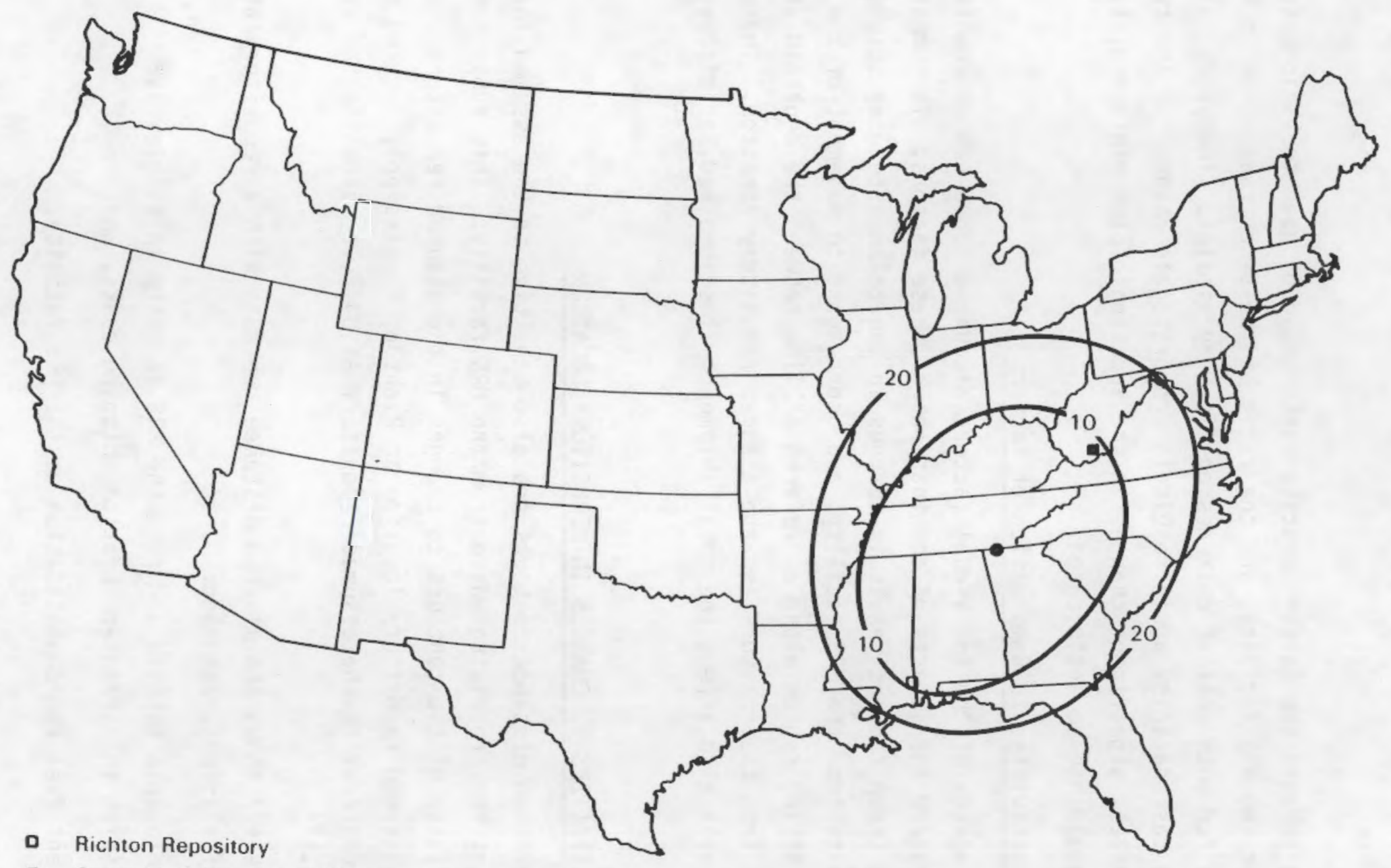

- Centroid of Spend Fuel Shipments from Reactors

- Location Providing Minimum Achievable Total Shipment Miles

FIGURE 6.7. Minimum Distance Contours Assuming Single-Cask Shipments to and from the MRS Facility, No Spent Fuel Rod Consolidation, and the First Repository at Richton, Mississippi 
Figure 6.8 shows the minimum distance contours for same set of conditions, except that spent fuel rod consolidation at the MRS facility is assumed to reduce the volume of the spent fuel by one-half. These figures correspond directly with Figures 6.1 and 6.3 , respectively, which were based on the assumption that the repository would be located at Hanford, Washington.

As shown in the figures, changes in the assumed location of the repository change the length and direction of the "reference" line between the repository and the centroid of the incoming spent fuel shipments from the reactors. The impacts resulting from changes in the other waste system logistics factors will again appear as movements of the contours along this line. However, because the distance between the centroid and the repository changes, the total shipment miles for a given set of conditions will change as the repository location changes. The sensitivities of the shipment mile totals to these changes are discussed in Section 7. 


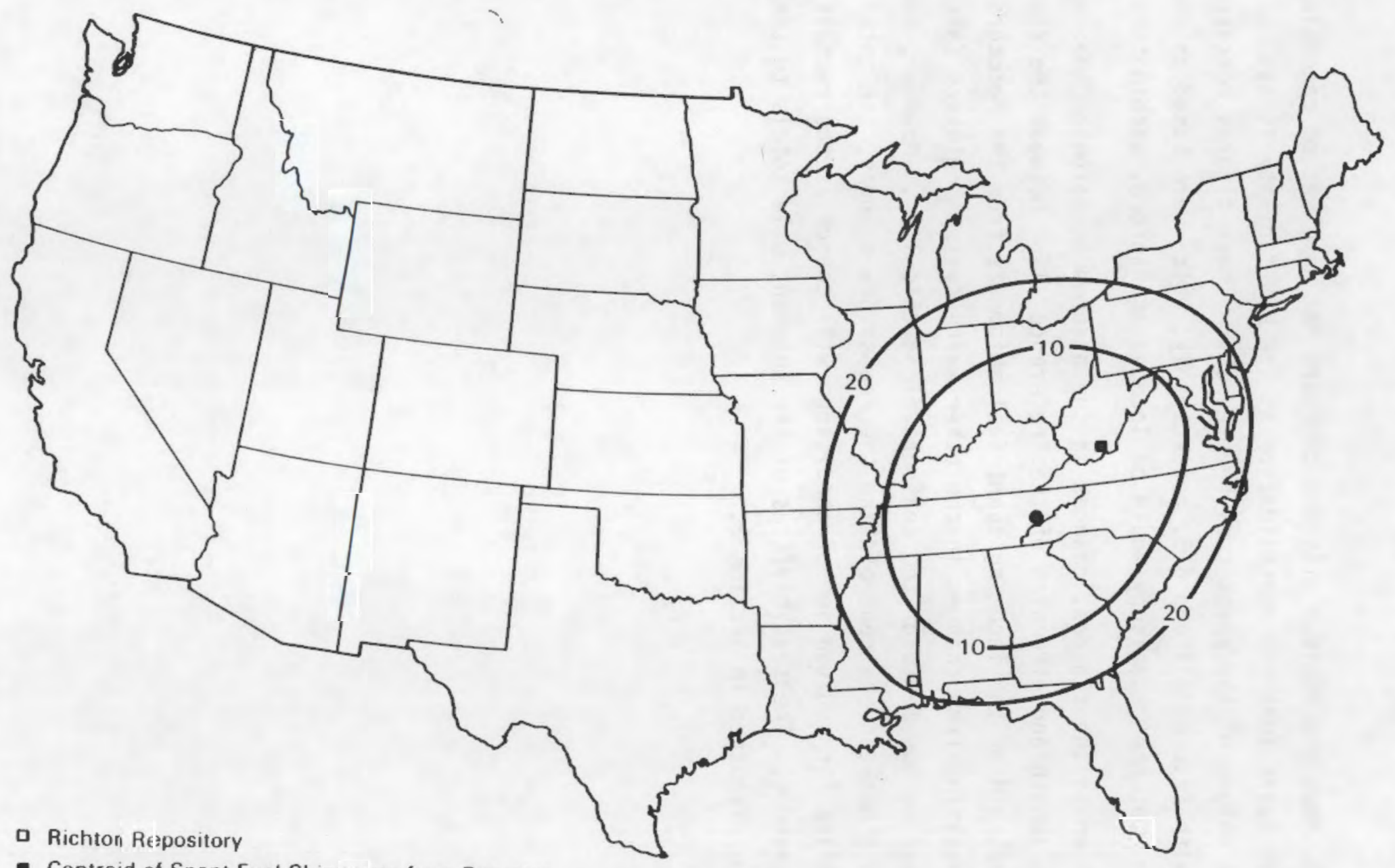

- Centroid of Spent Fuel Shipments from Reactors

- Location Providing Minimum Achievable Total Shipment Miles

FIGURE 6.8. Minimum Distance Contours Assuming Single-Cask Shipments to and from the MRS Facility, Spent Fuel Rod Consolidation (2:1), and the First Repository at Richton, Mississippi 


\subsection{SENSITIVITY OF SHIPMENT MILES TO WASTE SYSTEM LOGISTICS}

Total shipment miles are sensitive to changes in the factors governing the waste management system logistics. The location of the repository obviously affects the total shipment miles within the system. Factors relating to the fuel combining function of the MRS facility also influence the total shipment miles. The sensitivity of the shipment mile totals to these factors is discussed in this section.

For this section, comparisons of shipment mile totals are presented primarily using assumed repository locations at Hanford, Washington (BWIP) and at Richton, Mississippi. These two locations were chosen for the comparisons because they represent the two ends of a crescent that roughly defines all nine locations currently under consideration for the first repository (see Section 5.1.1). These two repository sites also represent the extremes of distance between the preferred siting region and the likely repository locations. Therefore, the results for any of the other repository locations under consideration would lie between those for BWIP and Richton. For each case presented, the MRS facility is assumed to be located at a point that would result in the minimum achievable total shipment miles (i.e., at the minimum point enclosed by the minimum distance contours). The figures in this section are all based on the use of rail shipments both to and from the MRS facility, except for truck shipments from those reactors not equipped to handle rail casks. Although these truck shipments account for a relatively small portion $(<10 \%)$ of the spent fuel shipped, they have a much larger influence on total shipment miles because of the small capacity of truck casks compared to rail casks.

\subsection{SPENT FUEL ROD CONSOLIDATION}

Spent fuel rod consolidation at the MRS facility to prepare the fuel for repository disposal would reduce the number of shipments required from the MRS facility to the repository and the associated shipment miles. The effects of various degrees of rod consolidation on the shipment mile totals, for assumed repository locations at BWIP and Richton, are summarized in Figure 7.1. The 


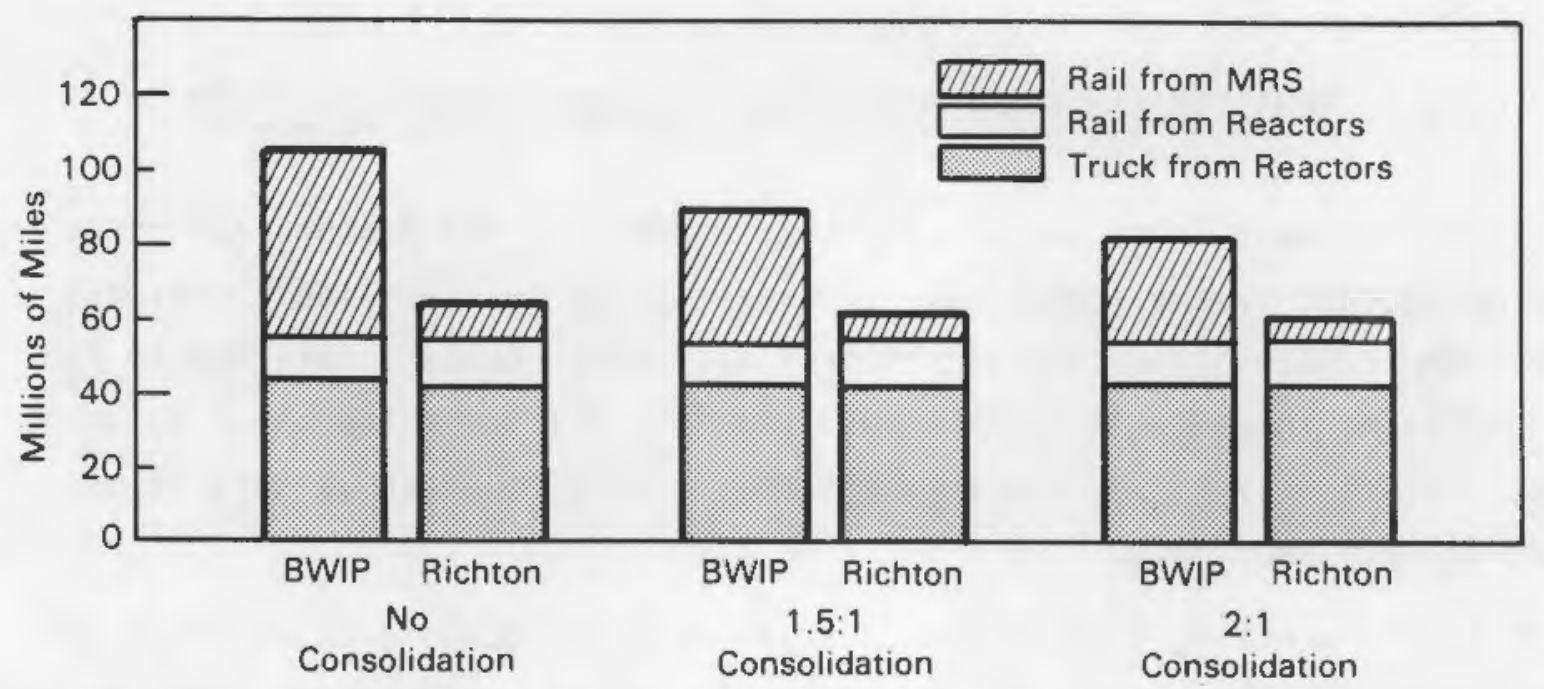

FIGURE 7.1. Impacts on Minimum Shipment Miles of Spent Fuel Rod Consolidation at the MRS Facility

information presented in the figure is based on 1) the use of current shipping cask technology (i.e., capacities of 1 PWR or 2 BWR assemblies per truck cask and 7 PWR or 18 BWR assemblies per rail cask) and 2) the use of single-cask shipments both to and from the MRS facility.

\subsection{MULTIPLE-CASK SHIPMENTS}

The use of multiple-cask shipments can also reduce the number of shipments and the shipment miles within shipment categories. Figure 7.2 presents a

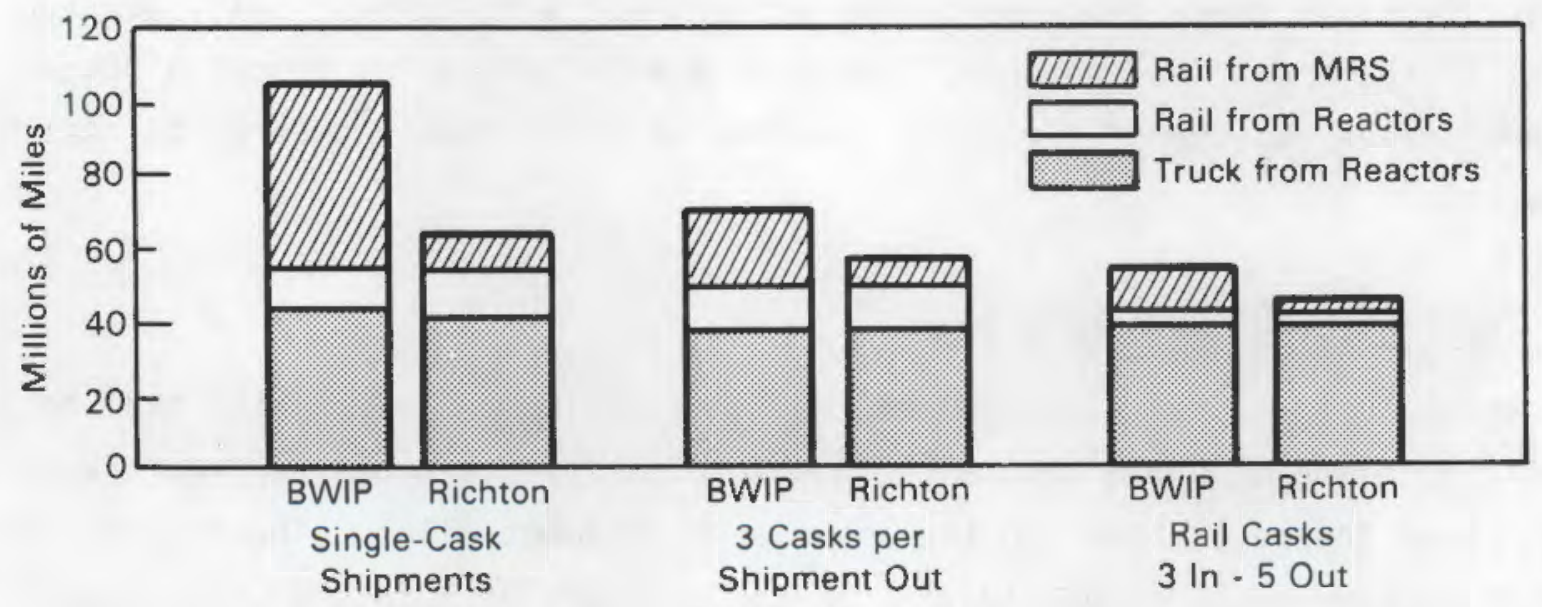

FIGURE 7.2. Impacts of Multiple-Cask Shipments on Minimum Shipment Miles 
summary of impacts on shipment miles resulting from the use of multiple-cask shipments. Comparative results are shown for the following:

- single-cask shipments both to and from the MRS facility;

- single-cask shipments to the MRS facility, with 3 casks per shipment from the MRS facility to the repository; and

- single-cask truck shipments and 3-cask rail shipments to the MRS facility, with 5 casks per shipment from the MRS facility to the repository.

No spent fuel rod consolidation is assumed at the MRS facility, and the cask capacities used are the same as those used for the preceding figure.

\subsection{SPENT FUEL SHIPPING CASK CAPACITIES}

As demonstrated in Section 6, changes in the capacities of the spent fuel casks for both truck and rail shipments will not significantly alter the balance between shipments to and shipments from the MRS and, therefore, will not have a major influence on the location of the preferred siting region. However, such changes will have substantial effects on the total shipment miles required. Figure 7.3 shows a comparison of the shipment miles by category using the current generation casks and using the DOE generic casks. The comparisons shown in the figure are based on the use of single-cask shipments

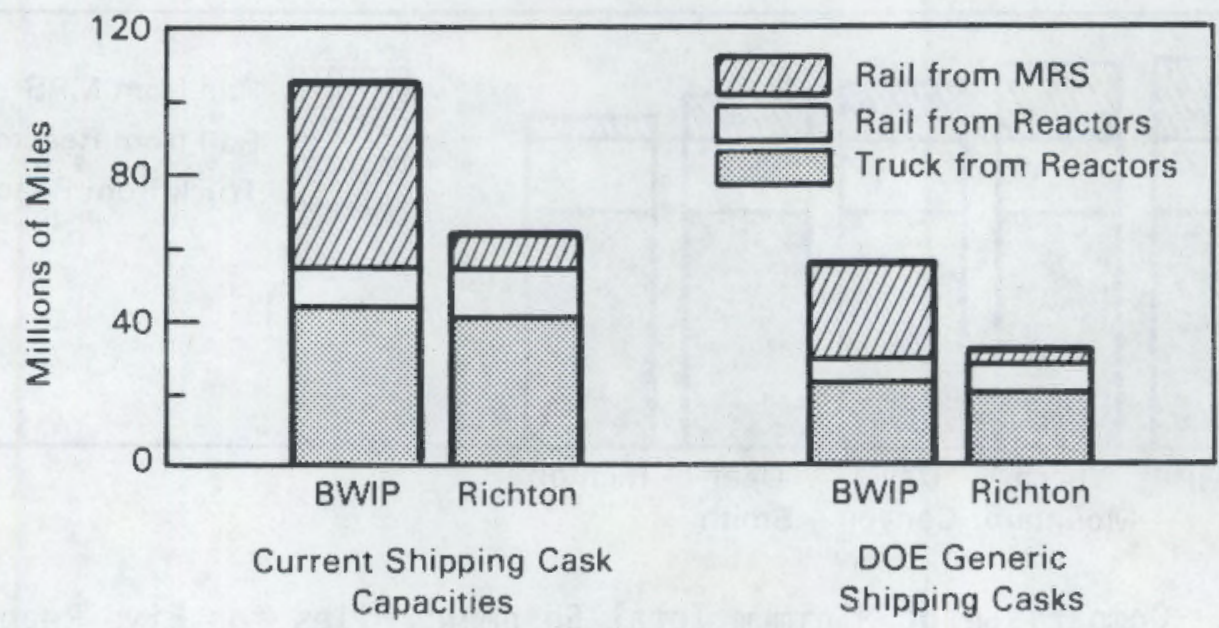

FIGURE 7.3. Impacts of Shipping Cask Capacities on Minimum Shipment Miles 
both to and from the MRS facility, with no rod consolidation at the MRS facility. Rod consolidation in conjunction with the use of the larger capacity casks would further reduce the total shipment miles for shipments from the MRS facility to the repository.

\subsection{COMBINATIONS OF LOGISTICS FACTORS}

A "representative" set of waste management system logistics factors was defined in Section 5 (see Table 5.2) to provide the basis for an example illustration of the analyses performed in this study. These factors included:

- the use of current shipping cask capacities;

- spent fuel rod consolidation (at a ratio of $1.5: 1$ ) at the MRS facility; and

- single-cask shipments to the MRS facility and 3 casks per shipment from the MRS facility to the repository.

Figure 7.4 shows a comparison of the total shipment miles, by category, for the five of the locations being considered for the first repository. The information represented by this figure is based on the "representative" set of logistics factors described above. The results shown in the figure illustrate the combined effects of simultaneous changes in various systen logistics factors.

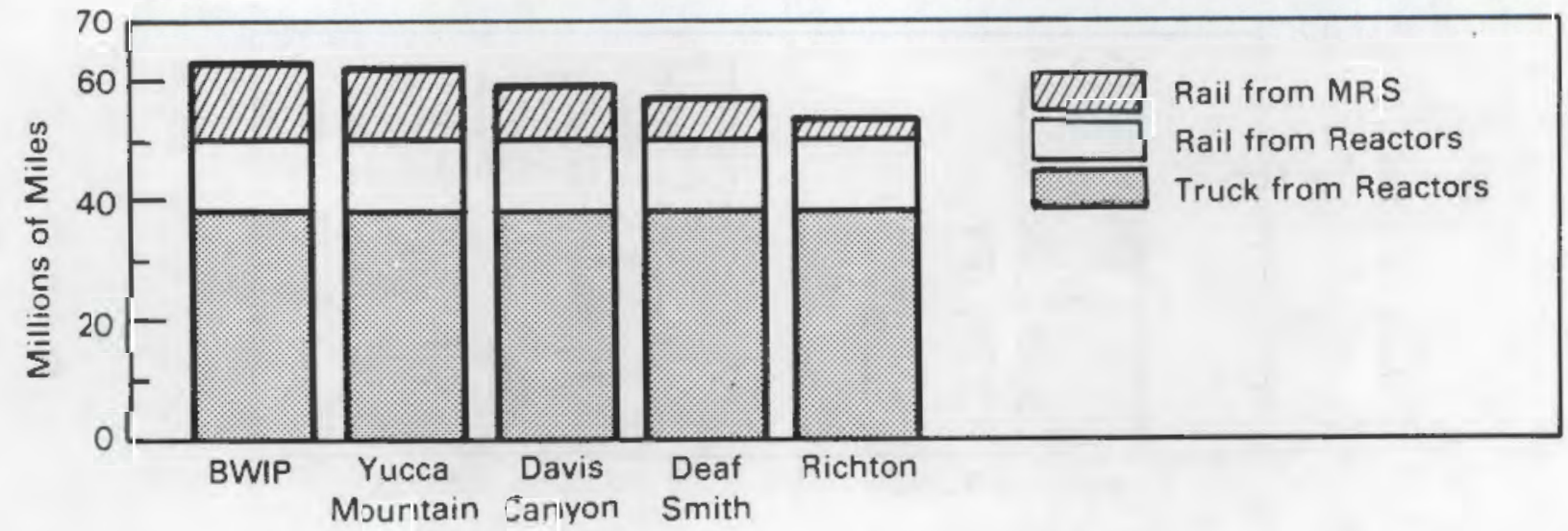

FIGURE 7.4. Comparison of Minimum Total Shipment Miles for Five Repository Locations, Based on a "Representative" Set of Waste Management System Logistics Factors 
Figure 7.4 also presents results for a broader range of repository locations than was included in the previous figures. For this particular set of logistics factors, the primary impact of repository location is on shipment miles from the MRS facility to the repository, resulting in only modest changes in the total shipment miles. In this case, the location resulting in the overall minimum total shipment miles for any repository is nearly at the centroid of the spent fuel shipments to the MRS facility. This result occurs because rod consolidation at the MRS facility and use of multiple-cask shipments from the MRS facility to the repository combine to provide substantial reductions in the number of shipments and the associated shipment miles from the MRS facility to the repository. In this situation, shipments to the MRS facility from the reactors control the minimization of total shipment miles.

The use of DOE generic casks rather than current-generation casks would result in a similar relationship between the different repository locations, although the magnitudes of the total shipment miles would be considerably reduced as shown previously in Figure 7.3 .

\subsection{SUMMARY SHIPMENT MILE SENSITIVITIES}

As fuel combining functions are added to the MRS facility, total shipment miles within the waste management system are progressively reduced. The magnitude and percentage of this reduction is strongly dependent on the location of the repository. Table 7.1 shows a comparison of total shipment miles and percentages of the total without an MRS facility in the system for selected combinations of logistic factors using assumed repository locations at BWIP and Richton. The table is based on accepting 70,000 MTU of spent fuel from existing or planned reactors throughout the U.S. As shown in the table, the shipment mile reductions resulting from fuel combining functions are more significant, both in terms of miles and in percentage, the greater the distance to the repository. 
TABLE 7.1. Comparison of Total Shipment Miles for Selected Combinations of Waste System Logistics Factors

\begin{tabular}{|c|c|c|c|c|}
\hline System Parameters & $\begin{array}{l}\text { BWIP (Hanford, } \\
\text { Total Shipment } \\
\text { Miles }\end{array}$ & $\begin{array}{l}\text { Washington) } \\
\% \text { of Total } \\
\text { Without MRS }\end{array}$ & $\begin{array}{l}\text { Richton, } \\
\text { Total Shipment } \\
\text { Miles } \\
\end{array}$ & $\begin{array}{l}\text { ississippi } \\
\% \text { of Total } \\
\text { Without MRS }\end{array}$ \\
\hline No MRS Facility in System(a) & $1.51 \times 10^{8}$ & 100 & $6.74 \times 10^{7}$ & 100 \\
\hline $\begin{array}{l}\text { MRS Facility (Mixed Shipments In/Rail } \\
\text { Shipments Out) }\end{array}$ & $1.05 \times 10^{8}$ & 69.5 & $6.31 \times 10^{7}$ & 93.6 \\
\hline $\begin{array}{l}\text { MRS Facility with } 1.5: 1 \text { Rod } \\
\text { Consolidation }\end{array}$ & $8.81 \times 10^{7}$ & 58.3 & $5.97 \times 10^{7}$ & 88.6 \\
\hline $\begin{array}{l}\text { MRS Facility with } 2: 1 \text { Rod } \\
\text { Consolidation }\end{array}$ & $7.90 \times 10^{7}$ & 52.3 & $5.77 \times 10^{7}$ & 85.6 \\
\hline $\begin{array}{l}\text { MRS Facility with No Rod Consolida- } \\
\text { tion, } 3 \text { Casks Per Shipment to } \\
\text { Repository }\end{array}$ & $7.02 \times 10^{7}$ & 46.5 & $5.63 \times 10^{7}$ & 83.5 \\
\hline MRS Facility (Example Case) (c) & $6.31 \times 10^{7}$ & 41.8 & $5.37 \times 10^{7}$ & 79.7 \\
\hline
\end{tabular}

(a) Spent fuel shipped directly from reactors to repository.

(b) For this and all following cases, all shipments are assumed to be by rail except from those

reactors lacking rail-cask handling capabilities.

(c) See Table 5.2. 


\subsection{CONCLUSIONS}

Based on the analyses performed for this study, a preferred geographic region was identified within which locating an MRS facility will reduce total shipment miles for all spent fuel shipments throughout the waste management system. This region is being used in other studies as a first level screening factor for identification and evaluation of potential MRS sites.

Total shipment miles throughout the waste management system are reduced because functions and operations performed at the MRS facility result in combining fuel into fewer shipments leaving the MRS facility for the repository than are received at the MRS facility from the reactors. There are three reasons for this reduction in total shipment miles:

1. Spent fuel assemblies arriving at the MRS facility in truck casks are shipped out in rail casks with capacities six to nine times greater than truck casks. (The capacities of the truck casks are limited because the weight limits for highway shipments are substantially lower than those for rail shipments.)

2. Spent fuel assemblies can be disassembled and consolidated into a smaller volume at the MRS facility.

3. It is feasible to load a larger number of casks per train on shipments moving between the MRS facility and the repository than on shipments from a reactor to the MRS facility. The practical number of casks per train is limited by the annual rate of spent fuel movement from a particular facility (e.g., reactor or MRS facility) and by the costs of having extra casks waiting for loading. Annual spent fuel discharges from a single reactor (approximately one-fourth to one-third of the reactor core) are much smaller than the total annual shipments from the MRS facility to the repository. In addition, reactors are not equipped for quick cask turnaround. Therefore, combining casks into single shipments from a reactor to the MRS facility would be much more limited than for shipments from the MRS facility to the repository. 
For any combination of waste management system logistics factors, a set of minimum distance contours can be identified within which locating an MRS facility would keep total shipment miles for all spent fuel shipments to and from the MRS facility within $20 \%$ of the lowest achievable total. For all such combinations of logistics factors that include significant combining of incoming spent fuel shipments to reduce the number of outgoing shipments, including the different possible repository locations, a composite "preferred" siting region can be defined by the intersection (i.e., overlapping) of the minimum distance contours for each combination of logistics factors. This composite "preferred" siting region, located in the central-eastern portion of the U.S., is shown in Figure 8.1.

Locating an MRS facility in the preferred region identified in Figure 8.1 will reduce total shipment miles associated with spent fuel shipments to and from the MRS facility. By locating an MRS facility within the preferred region, total shipment miles can be significantly reduced--achievable reductions can reach about $60 \%$ of the corresponding total if fuel was shipped directly from reactors to the first repository. The reduction in the total shipment miles is dependent on the specific MRS location within the preferred region, the specific repository location, and the particular set of waste management system logistics factors considered. The greatest reductions are for systems with the greatest fuel-combining operations at the MRS facility and with repository locations farthest from the centroid of the spent fuel shipments from the reactors.

As long as truck shipments from the reactors are changed to rail shipments from the MRS facility to the repository and either spent fuel rod consolidation or multi-cask shipments are used to further combine incoming spent fuel shipments to reduce the number of outgoing shipments, location of the MRS site in the preferred region identified in Figure 8.1 will reduce total shipment miles within the waste management system. This reduction in total shipment miles will occur:

- regardless of the location of the repository receiving the spent fuel shipments from the MRS facility; 


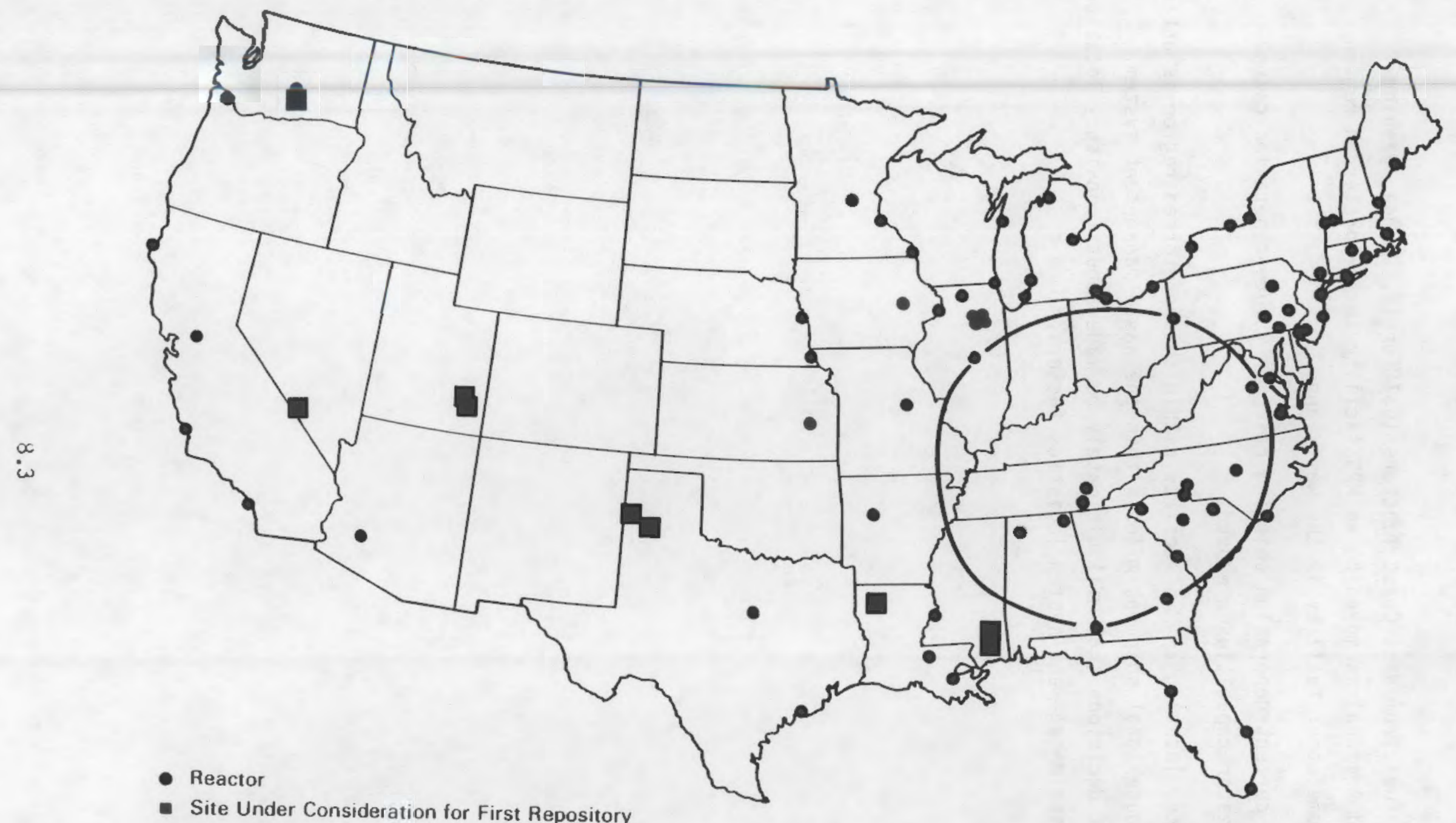

- Site Under Consideration for First Repository

FIGURE 8.1. The Preferred Siting Region for a Monitored Retrievable Storage (MRS) Facility 
- whether fuel from West Coast reactors (California, Oregon, Washington, and Arizona) is moved to an MRS facility in the preferred region or to some other facility in the west; and

- whether current-generation shipping casks or future-generation casks with greater capacities are used.

Therefore, locating an MRS facility within this preferred region is anticipated to reduce total shipment miles within the waste management system regardless of decisions that will ultimately be made about repository locations and other waste management system logistics factors. 
APPENDIX A

TRANSPORTATION RISK AND COST 
APPENDIX A

TRANSPORTATION RISK AND COST

Reduction of total shipment miles has been used in this study to assure that impacts from transporting spent fuel and other wastes within the waste management system are minimized. Two of the important transportation parameters affected by the location of the MRS facility are cost and risk. This appendix presents a discussion of the relationships between total shipment miles and the costs and risks associated with transporting spent fuel and other wastes within the waste management system. The analysis is based on available information. The emphasis was on determining the general nature and approximate magnitude of the effects of reducing shipment miles on the risks and costs in the waste management transportation system. The analysis provides the information needed to support the work in this document, but more detailed study would be needed to determine the exact numerical relationships between shipment miles and risk and costs.

The analysis has shown that transportation costs are not strongly dependent on the location of the MRS facility. Reducing total shipment miles by including an MRS facility in the waste management system does not result in significant changes in transportation costs. Locating the MRS facility to reduce shipment miles should result in the reduction of transportation related risks. This reduction in risks occurs primarily because truck shipments coming into the MRS are combined into a smaller number of outgoing rail shipments. The risks associated with the transportation operation are small, so the risk reduction is probably not significant from a pubic safety standpoint. Further details on the relationships between shipment miles and transportation risks and costs are provided in the following two sections. 


\section{A.1 RELATIONSHIP BETWEEN RISK AND SHIPMENT MILES}

An important premise of this study is that reducing total shipment miles within the waste management system also reduces the impacts associated with the transportation operations. This section examines the relationship between shipment miles and transportation risks. Preliminary analysis shows that transportation risks for a waste management system with an MRS facility located in the preferred region (i.e., the region that reduces total shipment miles) would be lower than transportation risks for a system in which fuel was shipped directly from reactors to a repository.

The risks resulting from the transportation of spent fuel include exposure of the public to radioactive materials that might be released from the shipping container in a very severe accident; exposure of people along the transportation corridor to low levels of radiation during normal transportation; fatalities and injuries produced in transportation accidents that do not release radioactive materials (i.e., risks that are independent of the cargo being carried); and risks from air pollution that could result from the transportation operation. For this analysis, the latter category of risks has been ignored because they are not an important contributor to the overall risks from transporting spent fuel. A discussion of the relationship between shipment miles and risks for each of the other risk categories is presented below. It should be noted that all of the risks associated with the transportation operation are very low. Although it is prudent to minimize these risks, small changes in the risks in either a positive or negative direction are not significant on an absolute scale.

Operations performed at the MRS facility will reduce total shipment miles in the waste management system because fuel will be combined into fewer shipments leaving the MRS facility for the repository than are received at the MRS from reactors. This results because:

- Spent fuel assemblies can be disassembled at the MRS facility and consolidated into a smaller volume. Consolidation factors approaching 1.5:1 are likely. A consolidation factor of $2: 1$ might be achieved with advanced technology. 
- Spent fuel assemblies arriving at the MRS facility in truck casks are shipped out in rajl casks that carry 6 to 9 times more fuel than the truck casks. This factor is further increased if the fuel is consolidated at the MRS facility. The reduction in shipment miles achieved by this shift from truck to rail modes is dependent on the location of the MRS facility. The greatest reduction is achieved if the MRS facility is located near reactors that will ship fuel by truck.

- Rail shipments leaving the MRS facility can include multiple casks per train.

The analysis in this section shows how each of these factors affects transportation risks.

Transportation risks in the waste management system can be calculated using the following relationship:

$$
R=r D S
$$

where

$R=$ the total risk, usualiy expressed as the expected number of fatalities;

$r=a$ unit risk factor, typically expressed as the expected number of fatalities per cask-mile

$D=$ the average number of miles per shipment and

$S=$ the number of shipments.

The unit risk factor changes with the transport mode. Unit factors are available for radiological risks from accidents and normal transportation and nonradiological risks from accidents.

Operations at the MRS facility will tend to reduce the total number of shipments made because of the modal shift that occurs from truck to more efficient rail casks. Consolidation would further reduce the number of shipments required. Use of multiple cask shipments on one train would only 
affect risks such as nonradiological risks from accidents that are dependent on train miles rather than on cask miles. (a)

\section{A.1.1 Radiological Risks from Accidents}

Shipping packages used to transport spent nuclear fuel are designed to meet very stringent safety standards established by the U.S. Nuclear Regulatory Commission (NRC) and the U.S. Department of Transportation (DOT). A number of detailed studies of spent fuel transportation risks have been performed. $(1,2,3)$ These studies have shown that very severe accident conditions are required to breach the containment integrity of these packages. In addition, the physical characteristics of spent fuel make it very difficult to disperse in even a very severe accident. Because of this, an accident that did compromise the shipping-package containment would most likely result in the release of only small amounts of radioactive material from the fuel. These releases could result in the population in the vicinity of the accident receiving relatively small radiation doses from radioactive materials that might be inhaled following the accident. These doses are not expected to be large enough to produce immediate health effects, but currently accepted dose response models predict that there would be a slight increase in the number of fatal cancers in the exposed population. These cancers would typically occur 15 years or more after the exposure.

Average radiological risks from accidents per mile of travel for truck and rail shipments of spent fuel have been developed in a recent study by the Transportation Technology Center. (4) Rail shipment risks were estimated to be $2.7 \times 10^{-10}$ latent cancer fatalities per cask-mile and truck risks were estimated to be $2.4 \times 10^{-11}$ latent cancer fatalities per cask-mile. Rail risks are higher because more severe accident environments are possible in train accidents and because a rail cask contains 6 to 9 times more fuel than a truck cask. The latter factor results in a larger predicted release from a rajl cask if an accident severe enough to breach the cask occurs. However, since fewer

(a) Cask miles are defined as the total number of miles traveled by a cask containing spent fuel or other wastes. Train miles are the number of miles traveled by the train carrying the cask. These two numbers are equal if the train is only carrying one cask. 
shipments are required with the higher capacity train casks, these values indicate that the risks from rail shipments and truck shipments are roughly equivalent for the transportation of a given amount of fuel. The higher unit risks associated with rail shipments are offset by the reduction in the number of shipments required. The modal shift from truck to rail resulting from operation of an MRS facility would therefore result in only small changes in the total risks from releases of radioactive materials in accidents.

If fuel is consolidated at the MRS facility, the total expected radiological risks from accidents would be expected to be reduced. The additional containment provided by the canister containing the consolidated fuel would reduce the probability that a release of radioactive material would occur in an accident. Consolidation would also reduce the number of shipments required, which would also tend to lower the risks. The larger amount of fuel in each cask would raise the risks because more material might be released if an accident severe enough to breach the cask occurred, but this is believed to be more than offset by the additional containment and the reduction in the number of shipments. A waste management system containing an MRS facility would therefore produce lower radiological risks from transportation accidents than a system without an MRS, if significant consolidation of the fuel is accomplished at the MRS facility. Shipment of more than one cask per train from the MRS facility to the repository would not significantly affect radiological accident risks.

\section{A.1.2 Radiological Risks in Normal Transportation}

NRC and DOT regulations require that spent fuel shipping casks provide shielding to reduce the radiation emitted from the fuel to safe levels at the surface of the cask. The low levels of radiation permitted by the regulations result in the people along the transportation corridor receiving very small radiation doses. Dose response models predict a slight increase in the incidence of cancer fatalities in the exposed population. Reference 4 aiso provides an estimate of the radiological risks during normal transport from truck and rail shipments of spent nuclear fuel. Truck risks are estimated to be $6.7 \times 10^{-9}$ latent cancer fatalities per cask-mile. Rail risks are estimated to be $2.7 \times 10^{-7}$ latent cancer fatalities per cask-mile. 
These estimates overstate the risks from rail shipments that would be made from the MRS facility to the repository. The risks from normal transport of spent fuel by rail are strongly dependent on the assumptions that are made about the amount of time that the shipment spends in rail yards awaiting a train for the next leg of the route. The estimates of yard time in Reference 4 are based on nationally averaged rail shipment data. These data predict that a rail shipment will average about $5.9 \mathrm{mi} / \mathrm{hr}$, including stops. Candidate repository sites currently under evaluation by DOE are predominantly located in the West. Rail shipments from the MRS facility to the repository would therefore be made primarily through the western U.S. Shipments in this part of the country typically spend less time in railyards than nationaliy averaged data would indicate. Information obtained from the Rockwell Hanford Traffic Manager's office indicates that shipments in the west average about $9.4 \mathrm{mi} / \mathrm{hr}$. This results in shorter total transit times. For a long trip such as would be made from the MRS facility to the repository, the amount of time spent in yards would be reduced by about 50\%. Based on these conditions, a revised rail shipment normal dose risk factor of $1.4 \times 10^{-7}$ latent cancer fatalities per cask-mile is estimated. Using these risk factors, the risks from normal transport of spent fuel by truck would be slightly lower than the risks for rail shipments for moving an equivalent amount of fuel a given distance. This indicates that the modal shift resulting from operation of an MRS facility would produce a slight increase in the risks from normal transport of spent fuel in the waste management system.

Consolidation of the fuel at the MRS facility would reduce routine radiological risks from transportation. Consolidation would permit each cask to carry more fuel, thus reducing the number of shipments required. The radiation levels permitted from the cask would not be expected to change significantly because they must meet DOT and NRC regulatory standards. Use of multiple cask rail shipments from the MRS facility to the repository would not affect routine radiological risks from these shipments.

\section{A.1.3 Nonradiological Risks from Accidents}

Trucks and trains carrying spent fuel will be involved in transportation accidents at about the same rate as trucks and trains carrying other kinds of 
hazardous materials. These accidents can result in fatalities and injuries to people in other vehicles involved in the accident, even when no radiation exposures occur. Reference 4 contains estimates of $2.9 \times 10^{-8}$ fatalities per shipment mile for accidents involving rail shipments and $8.8 \times 10^{-8}$ fatalities per shipment mile for truck shipments. These factors indicate that nonradiological risks from accidents involving spent fuel shipments would be substantially less for rail shipment than for truck shipment of an equivalent amount of fuel. The modal shift resulting from operation of an MRS facility would substantially decrease the nonradiological risks from transportation accidents.

Consolidation of the fuel at the MRS facility would further reduce these risks. Use of multiple-cask shipments from the MRS facility to the repository would also reduce risks from nonradiological accidents. Nonradiological risks from rail shipments depend on train miles rather than cask miles. Multiplecask shipments reduce train miles and therefore reduce the number of accidents that could produce nonradiological effects.

\section{A.1.4 Total Risks}

The unit risk factors for truck and rail shipments of spent fuel in the MRS system are summarized in Table A.l. The total risks indicate that for each shipment of spent fuel, risks per mile of shipment by truck are about half of the risks for shipment by rail. The modal shift from truck to rail resulting from operation of the MRS facility should reduce risks to the public from transportation of spent fuel in the waste management system, because the increased capacity of the rail casks reduces the required number of shipments by a factor of 6 to 9. Consolidation of the fuel at the MRS facility would further reduce these risks. Use of multiple-cask shipments would also have an important affect in lowering risk because nonradiological accident risks are reduced.

\section{A.2 RELATIONSHIP BETWEEN TRANSPORTATION COST AND SHIPMENT MILES}

For a waste management system which includes an integral MRS facility, transportation costs for spent fuel were found to be significantly less sensitive than total shipment iniles to the location of the MRS facility. Therefore, locating an MRS facility in the preferred siting region identified in this 
TABLE A.1. Summary of Unit Risks from Shipment of Spent Nuclear Fuel by Truck and Train

\begin{tabular}{|c|c|c|}
\hline \multirow[b]{2}{*}{ Risk Category } & \multicolumn{2}{|c|}{ Trict } \\
\hline & Truck & Rail \\
\hline Routine Radiological & $6.7 \times 10^{-9}$ & $1.4 \times 10^{-7}$ \\
\hline Radiological Accident & $2.4 \times 10^{-11}$ & $2.7 \times 10^{-10(a)}$ \\
\hline Nonradiological Accident & $8.8 \times 10^{-8}$ & $2.9 \times 10^{-8(a)}$ \\
\hline TOTALS & $9.5 \times 10^{-8}$ & $1.6 \times 10^{-7}$ \\
\hline
\end{tabular}

(a) Use of multiple-cask shipments would not significantly change the accident risks per mile traveled and, thus, the values shown are equivalent to fatalities/shipment-mi .

study rather than in some other region will also keep total transport costs within the waste management system within $20 \%$ of the estimated minimum achievable total. In other words, no cost penalty results from locating an MRS facility within the preferred region.

Transportation costs are a complex function of a number of logistics factors including the mix of truck and rail shipments, the distances between various facilities, cask payloads and transport speeds. Because of this complexity, there is not a direct or one-to-one correspondence between transport cost and total system miles.

A series of sensitivity analyses were performed using the TRANSIT model (described in Appendix B). These analyses were based on conditions in which 70,000 MTU of spent fuel from all reactors are transported through an MRS facility to a repository. All shipments to and from the MRS facility were assumed to be by rail, except from those reactors without capability to handle the large rail casks. The following current-generation cask capacities were assumed for these analyses:

- 1 PWR or 2 BWR assemblies per truck cask

- 7 PWR or 18 BWR assemblies per rail cask

Various degrees of spent fuel consolidation at the MRS facility were examined. 


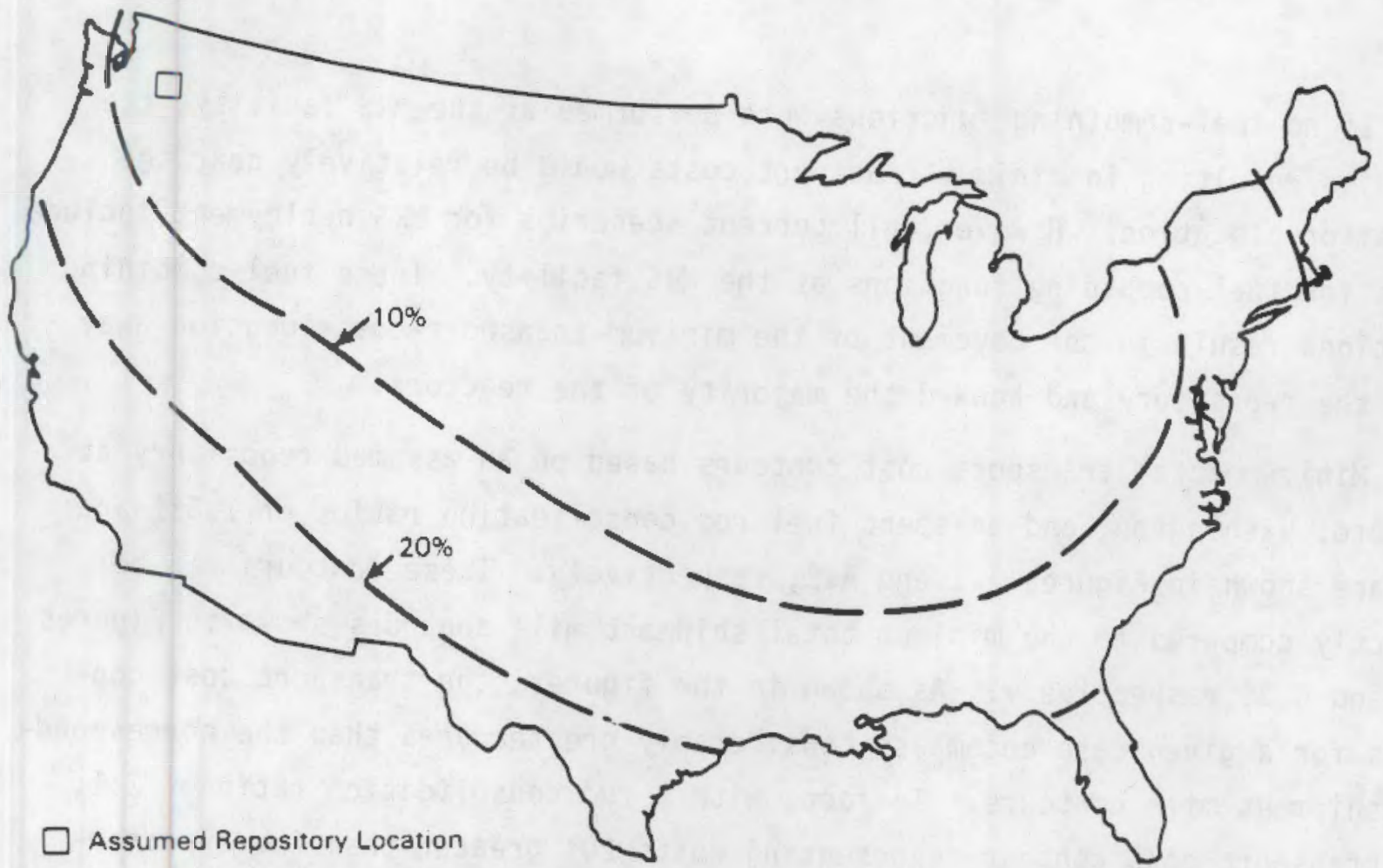

FIGURE A.1. Minimum Transport Costs Contours Assumina Single-Cask Shipments to and from the MRS Facility, Spent fuel Rod Consolidation (1.5:1), and the First Repository at Hanford

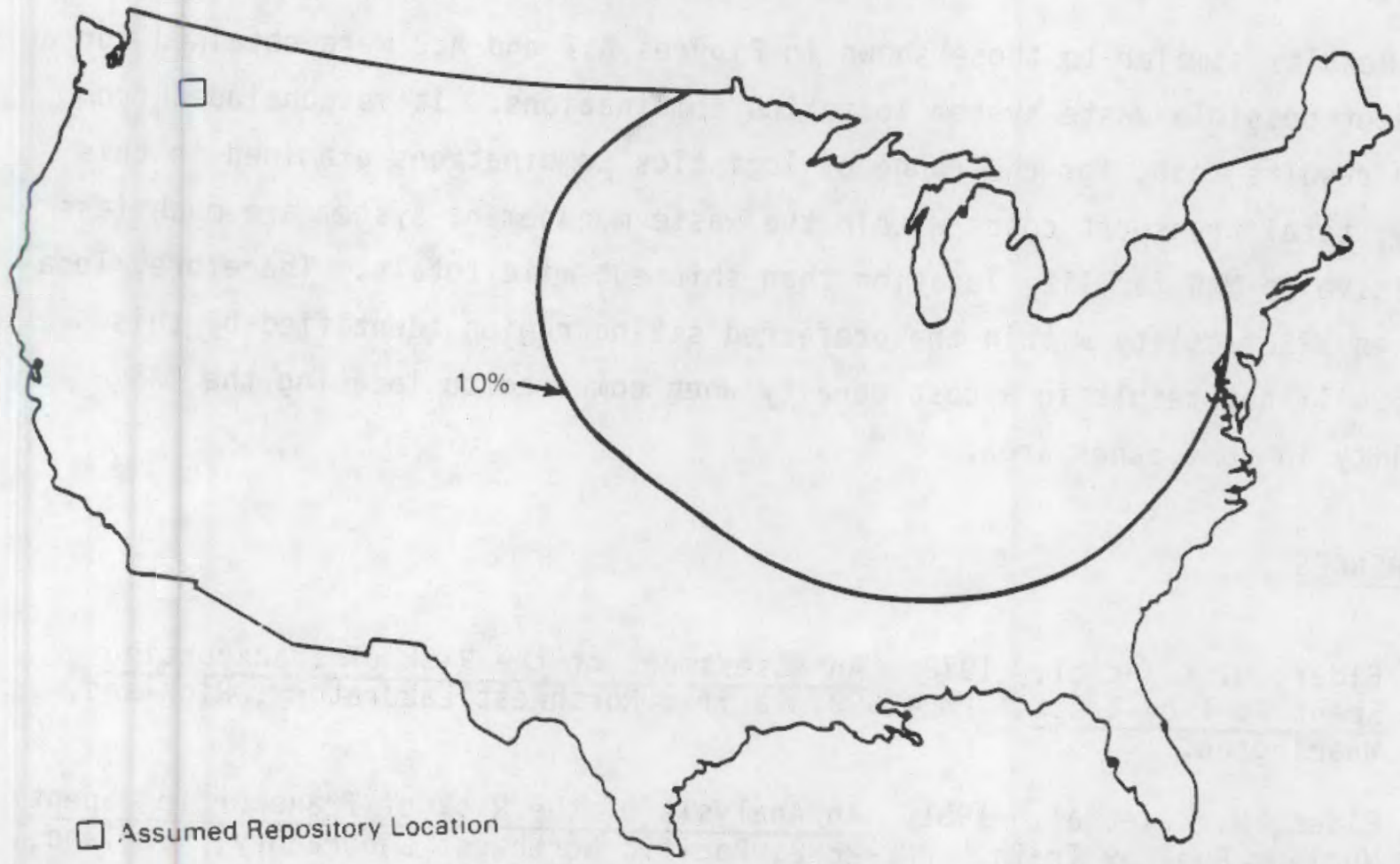

FIGURE A.2. Minimum Transdort Costs Contours Assuming Single-Cask Shipments to and from the MRS Facility, Spent Fuel Rod Consolidation (2:1), and the First Repository at Hanford 
If no fuel-combining functions were performed at the MRS facility, the location resulting in minimum transport costs would be relatively near the repository location. However, all current scenarios for MRS deployment include plans for fuel-combining functions at the MRS facility. These fuel-combining functions result in the movement of the minimum-transport-cost location away from the repository and toward the majority of the reactors.

Minimum total transport cost contours based on an assumed repositary at Hanford, Washington, and on spent fuel rod consolidation ratios of $1.5: 1$ and 2:1 are shown in Figures $A .1$ and $A .2$, respectively. These contours can be directly compared to the minimum total shipment mile contours shown in figures 6.2 and 6.3, respectively. As shown in the figures, the transport cost contours for a given case encompass considerably greater area than the corresponding shipment mile contours. In fact, with a rod consolidation ratio of $2: 1$, the transport cost contour representing costs $20 \%$ greater than the expected minimum total is not shown because it encompasses the entire 48 contiguous states.

Results similar to those shown in Figures A.1 and A.2 were obtained for a range of possible waste system logistics combinations. It is concluded from these results that, for the range of logistics combinations examined in this study, total transport costs within the waste management system are much less sensitive to MRS facility location than shipment mile totals. Therefore, locating an MRS facility within the preferred siting region identified by this study will not result in a cost penalty when compared to locating the MRS facility in some other area.

\section{REFERENCES}

1. Elder, H. K. et al. 1978. An Assessment of the Risk of Transporting Spent Fuel by Truck. PNL-2588, Pacific Northwest Laboratory, Richland, Washington.

2. Elder, H. K. et al. 1981. An Analysis of the Risk of Transporting Spent Nuclear Fuel by Train. PNL-2682, Pacific Northwest Laboratory, Richland, Washington. 
3. NRC. 1977. Final Environmental Statement on the Transportation of Radioactive Materiat by Air and Other Modes. NUREG-0170, U.S. Nuclear Regulatory Commission, Washington, D.C.

4. Neuhauser, K. S. et al. 1984. A Preliminary Cost and Risk Analysis for Transporting Spent Fuel and High Level Wastes to Candidate Repository Sites. SAND84-1795, Sandia National Laboratory, Albuquerque, New Mexico. 


\section{APPENDIX B}

ANALYTICAL METHODS AND TOOLS 
APPENDIX B

ANALYTICAL METHOOS AND TOOLS

This appendix provides further details on the analytical methods and tools used to perform the siting region analyses. These details support the summary descriptions provided in the main body of the report. Included are discussions of the methods and tools that were used for each type of analysis performed:

- identification of specific quantities and locations of the spent fuel to be received at the MRS facility;

- calculation of the travel distances and corresponding distance contours; and

- calculation of total shipment miles by shipment category.

Other than for the identification of the quantities and locations of the spent fue1, separate analyses were required for each combination of waste management system logistics factors (i.e., each logistics case) that was examined.

\section{B.1 IDENTIFICATION OF THE SPENT FUEL}

The region in which locating an MRS facility would keep total shipment miles throughout the waste management system within some percentage of the minimum achievable total depends on a number of factors. Many of these factors relate to the spent fuel that is to be received, as follows

- the quantity of spent fuel to be received from each reactor;

- the type of spent fuel (i.e., PWR or BWR) stored at each reactor (because shipping cask capacities are dependent on the type of the fuel);

- the location of each reactor that will be shipping spent fuel to the MRS facility; and 
- the shipping cask handling capabilities and any other potentia? access limitations at each reactor (i.e., whether the larger rail casks can be handled or shipment will have to be restricted to truck casks).

The first factor, the quantity of spent fuel to be received from each reactor, further depends on the total amount of fuel to be received at the MRS facility (i.e., the lifetime facility throughput). Although all of the spent fuel at each reactor will eventually be received into the waste management system for disposal, the lifetime throughput of the MRS facility may be less than the total projected spent fuel discharges from all reactors.

The basic spent fuel information used for the siting region analyses is presented and discussed in Appendix $C$. With the exception of the quantities of spent fuel that are to be received from each reactor, the information in Appendix $C$ was drawn directly from Reference 1 . The discussion here is 1 imited to how this information was interpreted to identify the quantities of spent fuel for use in the siting region analyses.

Reference 1 provides projections of spent fuel quantities on a reactor-byreactor, year-by-year basis. Assuming that the spent fuel is received on an oldest-first basis, the amount of fuel to be received from each reactor can be easily approximated by determining the year in which the total inventory of spent fuel is closest to the total required and using the inventories at each reactor in that year.

For the siting region analyses, a waste management system simulation model called WASTES (Waste System Transportation and Economics Simulation) was used to identify the spent fuel quantities to be received from each reactor. (2) The WASTES model was developed jointly by the MRS Program and DOE's Transportation Technology Center (TTC) for use in analyzing the effects of various policy decisions, waste system logistics considerations, and facility operating schedules. The use of the WASTES simulation model has several advantages: 
- The total quantity of fuel to be received from each reactor can be obtained more accurately, down to individual assemblies from each reactor, by simulating the receipt of individual full cask loads of spent fuel.

- The use of full cask loads of spent fuel whenever possible can be ensured to realistically reflect the way fuel will be received.

- The exclusion of receipts from specific reactors (e.g., those in the West Coast states) can be readily simulated to allow examination of the resulting affects.

The primary input specifications required by WASTES to obtain the information needed for the travel distance calculations were:

- the total amount of fuel to be received (e.g., 70,000 MTU);

- the order in which the fuel is to be received (i.e., for this study, strictly the oldest fuel first);

- the shipping cask capacities (to ensure the receipt of full cask loads of spent fuel); and

- any reactors that are to be excluded from shipping fuel to the MRS facility.

Four major cases were developed to provide the information needed for the calculation of travel distances and contours:

Case 1. 70,000 MTU of spent fuel from all reactors.

Case 2. 70,000 MTU of spent fuel excluding wastes from reactors in the West Coast States.

Case 3. All spent fuel (about $100,000 \mathrm{MTU}$ ) from all reactors.

Case 4. All spent fuel excluding that from the West Coast reactors (a total of about $90,000 \mathrm{MTU})$.

The last two cases correspond to an extended MRS operating 1 ifetime. Detailed information resulting from these four WASTES analyses is presented in Appendix $C$. 


\section{B.2 CALCULATION OF TRAVEL DISTANCES AND CONTOURS}

The spent fuel information described above is used to calculate the number of spent fuel shipments required within the waste management systern from each reactor to the MRS facility as well as from the MRS facility to a repository. These spent fuel shipments determine the corresponding travel distances and distance contours. The results of these calculations can then be used to identify the region within which locating an MRS facility would keep total shipment miles within a given percentage of the minimum achievable total.

For each combination of waste system logistics factors analyzed, the total shipment miles are calculated by summing the distances for all shipments to and from the MRS facility. To locate the region for which travel distances would be minimized, a geographical grid is defined and total shipment miles are calculated for an assumed MRS facility at each point on the grid (i.e., each intersection of the grid lines as shown in Figure B.1). To provide increased accuracy in identifying specific locations, the grid can be redefined to increase the number of grid lines or to reduce the area included. Travel distances between any two points are derived based on great-circle distances which have been adjusted upward to compensate for the average distance increases for rail and highway travel over the theoretical great-circle distances.

Once the total shipment miles have been calculated for each point on the grid, the grid point corresponding to the MRS location resulting in the minimum achievable total shipment miles can be identified. In addition, contours of the calculated shipment mile totals can be drawn by interpolating (i.e., estimating values) between the points on the grid. For this study, contours were drawn for shipment mile totals that were $10 \%$ and $20 \%$ greater than the minimum calculated total. The accuracy of the resulting contours depends, of course, on the resolution (i.e., spacing) of the grid used.

Two similar but separate sets of analytical tools were used to calculate total shipment miles and draw the associated contours. One of these tools was TRANSIT, a personal-computer-based mode? for analysis of radioactive waste transportation logistics. This model is currently under development and peer review for DOE by TTC. Documentation on the TRANSIT model is expected to be published in the near future. The other set of tools involved simple 
Total shipment miles are calculated for an assumed MRS facility at each point on grid

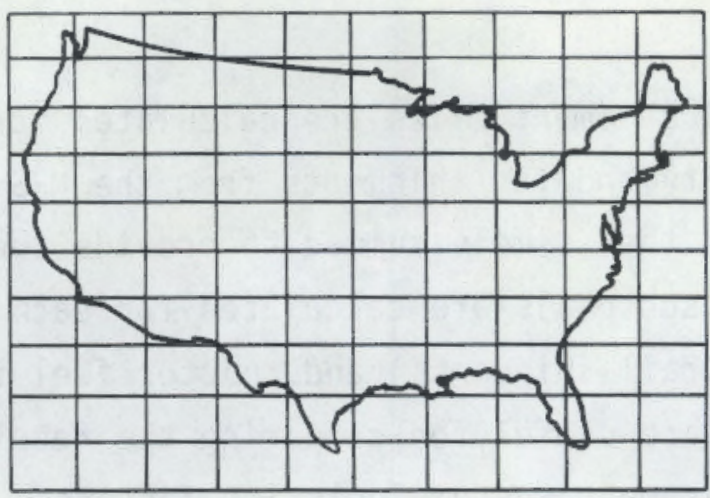

The size and location of the grid and the number of grid lines can be varied as needed for accuracy

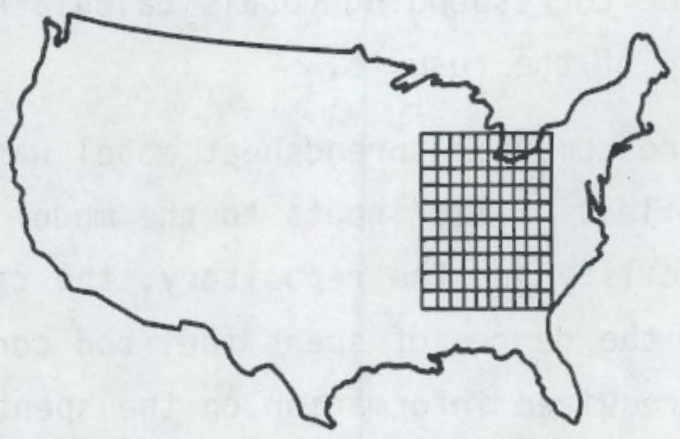

FIGURE B.1. Transportation Distance Calculations

procedures which were developed using the mapping capabilities of the OISSPLA[TM] (Display Integrated Software System and Plotting Language) system, a commercial software product of Integrated Software Systems Corporation which runs on both mainframe and minicomputers. (3) These two sets of analytical tools were benchmarked against each other to ensure the compatibility of the results obtained, so that the tools could be used interchangably as desired.

\section{B.3 CALCULATION OF TOTAL SHIPMENT MILES}

After the MRS location yielding the minimum achievahle total shipment miles for the combination of logistics factors being considered is identified and the associated travel distance contours are determined, the total shipment miles that would result from this combination of factors are calculated. Although these totals are the same as those derived and used internally in the previous calculations, they are not directly obtainable in the form and detail desired from the previous calculations. 
Total shipment miles are calculated for shipments from each reactor to the MRS facility and for shipments from the MRS facility to the repository. These totals are then simply summed to provide the overall total shipment miles. In addition, subtotals are calculated for each combination of travel mode (i.e., truck vs. rail shipments) and reactor fuel type (i.e., PWR vs. BWR). These subtotals are useful for comparing the results for alternative combinations of waste management system logistics factors.

Adjusted great-circle distances were again used to calculate the distances between locations. The total shipment miles calculated in this step were compared to the corresponding totals calculated in previous steps to verify the consistency of the results.

A micro-computer spreadsheet model was developed for calculating the total shipment miles. Basic inputs to the model included the assumed locations of the MRS facility and the repository, the capacities of the spent fuel shipping casks, and the degree of spent fuel rod consolidation achieved. A data base providing required information on the spent fuel at each reactor was also included in the model (corresponding to the appropriate information from Appendix C). This information was then used to calculate total shipment miles and total numbers of shipments for the overall waste management system and for the following categories:

- shipments from the reactors into the MRS facility, with subtotals for each combination of shipping mode (i.e., rail or truck) and fuel type (i.e., PWR or BWR);

- shipments from the MRS facility to the repository, with subtotals for each fuel type; and

- overall system subtotals for truck shipments, rail shipments into the MRS facility, and rail shipments from the MRS facility to the repository. 
By comparing the resuits for alternative combinations of logistics factors, the calculated total shipment miles provide a basis for determining the sensitivity of potential savings in shipment miles resulting from locating the MRS facility at the specified location to possible changes in the waste system logistics.

\section{REFERENCES}

1. Heeb, C. M., R. A. Libby, and G. M. Holter. 1985. Reactor-Specific Spent Fuel Discharge Projections: 1984 to 2020, PNL-5396. Pacific Northwest Laboratory, Richland, Washington.

2. Shay, M. R., A. L. Thorpe, and G. W. McNair. 1985. WASTES: Waste System Transportation and Economic Simulation, PNL-5413. Pacific Northwest Laboratory, Richland, Washington.

3. DISSPLA (Display Integrated Software System and Plotting Language), Version 9.0, (October 1981), Integrated Software Systems Corporation, San Diego, California. 
APPENDIX C

SPENT FUEL INFORMATION USED FOR SITING REGION ANALYSES 
APPENDIX C

SPENT FUEL INFORMATION USEO FOR SITING REGION ANALYSES

The spent fuel information presented in this appendix was used for the MRS siting region analyses to provide the basis for calculating the number of spent fuel shipments required for each waste system configuration considered. This spent fuel information was derived from the projections included in the Energy Information Administration (EIA) No New Orders Case, based on information reported in "Reactor-Specific Spent Fuel Discharge Projections: 1984 to 2020." (1)

This appendix provides a discussion of the sources used to develop the spent fuel information required for this study. Following this, the detailed spent fuel information that was used is presented.

\section{C.1 SPENT FUEL INFORMATION SOURCES}

EIA is responsible for providing projections of the future installed nuclear electrical generating capacity of nuclear power plants and the associated projections of spent fuel discharges from the plants that will be operating. These projections, which are updated and published annually, (2) are made for differing sets of assumptions about the growth of the nuclear electricity-generating capacity. These growth assumptions range from no new orders for nuclear power plants (beyond those currently operating or planned by the utilities) through various levels of growth in new orders for nuclear plants.

The EIA growth projections based on the assumption of no new orders for nuclear plants (the No New Orders Case) was used for this study. The No New orders Case, unlike the other EIA growth cases, does not include any nuclear power plants beyond those currently operating or planned. The results of the siting analyses depend on the locations of the reactors. Any projections which assume construction of additional reactors beyond those currently on order require predictions of locations for these future reactors. The No New Orders 
Case was judged to accurately represent spent fuel discharges that can be anticipated from currently planned and operating nuclear power plants over the period of interest, without introducing significant errors in anticipated spent fuel quantities if new plants are constructed and without requiring additional analytical complications to account for currently unsited power plants.

The spent fuel projections in the EIA No New Orders Case are given on a year-by-year, reactor-by-reactor basis. Using this information, specific amounts of fuel for acceptance at an MRS facility (e.g., the oldest 70,000 MTU) can be readily identified. Through the total operating lifetimes of all of the reactors, the No New Orders Case contains a projected total of about 100,600 MTU of spent fuel. Inventories at currently operating away-fromreactor spent fuel storage facilities are included.

In addition to projected spent fuel inventories and discharges, the EIA information identifies the locations of the nuclear power plants; the siting region analyses used the longitude-latitude coordinates given for each reactor. Information is also included on the current cask handling capabilities at each plant as well as on rail spurs, roads, and other access conditions. This information was used in this study to calculate travel distances and to determine the appropriate transportation mode for shipments to the MRS from the reactors.

A more detailed description of the EIA electricity-generation growth projections and the associated spent fuel discharge projections is included in Reference 1.

\section{C.2 DETAILED SPENT FUEL INFORMATION USED FOR THIS STUDY}

Four basic sets of spent fuel information were derived from the ElA No New Drders Case for use in this study. These four sets of data correspond to the following conditions:

1. Deployment of an MRS facility with a 70,000-MTU lifetime throughput to receive the oldest spent fuel from all reactors.

2. Deployment of an MRS facility to receive all spent fuel from all reactors. 
3. Deployment of a 70,000-MTU MRS facility to receive the oldest spent fuel from all reactors except those located in the West coast states (i.e., Arizona, California, Oregon, and Washington).

4. Deployment of an MRS facility to receive all spent fuel from all reactors except those located in the West Coast states.

The summary characteristics of these four sets of spent fuel information are provided in Table C.1. Detailed listings of the information included in the four data sets are presented in Tables $C .2$ through $C .5$, respectively. The geographic distribution of the spent fuel is discussed in Appendix 0 . 
TABLE C.1. Summary Characteristics of the Spent Fuel Information Used for the MRS Siting Region Analyses

\begin{tabular}{|c|c|c|c|c|c|c|}
\hline $\begin{array}{c}\text { MRS Lifetime } \\
\text { Capacjty } \\
\end{array}$ & $\begin{array}{l}\text { Facilities } \\
\text { Excluded (a) }\end{array}$ & $\begin{array}{c}\text { Spent Fuel } \\
\text { Type } \\
\end{array}$ & $\begin{array}{l}\text { Shipping } \\
\text { Mode }(6) \\
\end{array}$ & $\begin{array}{l}\text { Number of } \\
\text { Facilities }\end{array}$ & $\begin{array}{l}\text { Spent Fuel } \\
\text { Assemblies }\end{array}$ & $\begin{array}{c}\text { Metric } \\
\text { Tons }\end{array}$ \\
\hline $70,000 \mathrm{MTU}$ & None & $\begin{array}{l}\text { PWR } \\
\text { PWR } \\
\text { BWR } \\
\text { BWR }\end{array}$ & $\begin{array}{l}\text { Rail } \\
\text { Truck } \\
\text { Rail } \\
\text { Truck }\end{array}$ & $\begin{array}{r}57 \\
27 \\
35 \\
8 \\
\end{array}$ & $\begin{array}{r}67,857 \\
34,271 \\
112,261 \\
31,771 \\
\end{array}$ & $\begin{array}{r}29,606.73 \\
14,498.96 \\
20,196.77 \\
5,697.34 \\
\end{array}$ \\
\hline TOTALS & & & & 127 & 246,160 & $69,999.80$ \\
\hline All available & None & $\begin{array}{l}\text { PWR } \\
\text { PWR } \\
\text { BWR } \\
\text { BWR }\end{array}$ & $\begin{array}{l}\text { Rail } \\
\text { Truck } \\
\text { Rail } \\
\text { Truck }\end{array}$ & $\begin{array}{r}57 \\
27 \\
35 \\
8 \\
\end{array}$ & $\begin{array}{r}103,866 \\
42,707 \\
161,973 \\
44,157 \\
\end{array}$ & $\begin{array}{r}45,400.11 \\
18,123.36 \\
29,175.39 \\
7,929.58 \\
\end{array}$ \\
\hline TOTALS & & & & 127 & 352,703 & $100,628.44$ \\
\hline $70,000 \mathrm{MTU}$ & $\begin{array}{l}\text { Western } \\
\text { Reactors }(c)\end{array}$ & $\begin{array}{l}\text { PWR } \\
\text { PWR } \\
\text { BWR } \\
\text { BWR }\end{array}$ & $\begin{array}{l}\text { Rail } \\
\text { Truck } \\
\text { Rail } \\
\text { Truck }\end{array}$ & $\begin{array}{r}50 \\
24 \\
34 \\
7 \\
\end{array}$ & $\begin{array}{r}64,644 \\
33,292 \\
123,304 \\
30,974 \\
\end{array}$ & $\begin{array}{r}28,269.29 \\
13,958.27 \\
22,231.71 \\
5,540.34 \\
\end{array}$ \\
\hline TOTALS & & & & 115 & 252,214 & $69,999.61$ \\
\hline All available & $\begin{array}{l}\text { Western } \\
\text { Reactors }\end{array}$ & $\begin{array}{l}\text { PWR } \\
\text { PWR } \\
\text { BWR } \\
\text { BWR }\end{array}$ & $\begin{array}{l}\text { Rail } \\
\text { Truck } \\
\text { Rail } \\
\text { Truck }\end{array}$ & $\begin{array}{r}50 \\
24 \\
34 \\
7 \\
\end{array}$ & $\begin{array}{r}90,455 \\
36,704 \\
161,539 \\
37,280 \\
\end{array}$ & $\begin{array}{r}39,633.30 \\
15,363.70 \\
29,144.40 \\
6,683.65 \\
\end{array}$ \\
\hline TOTALS & & & & 115 & 325,978 & $90,825.05$ \\
\hline
\end{tabular}

(a) Indicates where facilities have been excluded from shipping to the MRS facility (e.g., the western reactors may ship spent fuel to some other location).

(b) Facilities are designated as shipping by rail, except where current cask handing capabilities or site access limitations allow shipment only by truck. (3)

(c) Includes those reactors in Arizona, California, Dregon, and Washington. 
TABLE C.2. Spent Fuel Information for 01 dest 70,000 MTU at A11 Reactors

\begin{tabular}{|c|c|c|c|c|c|c|}
\hline Facility & Type & $\begin{array}{l}\text { North } \\
\text { Latitude }\end{array}$ & $\begin{array}{c}\text { West } \\
\text { Longitude }\end{array}$ & $\begin{array}{l}\text { Number of } \\
\text { Assemblies }\end{array}$ & $\begin{array}{l}\text { Metric } \\
\text { Tons } \\
\end{array}$ & $\begin{array}{l}\text { Shipping } \\
\text { Mode }\end{array}$ \\
\hline MAINE YANKEE & PWR & 43.57 & 69.42 & 1807 & 679.21 & Rail \\
\hline PILGRIM-1 & $B W R$ & 41.57 & 70.35 & 3401 & 614.28 & Truck \\
\hline SEABROOK-1 & PWR & 42.54 & 70.51 & 1335 & 565.33 & Rail \\
\hline MILLSTONE-1 & $B W R$ & 41.19 & 72.10 & 3983 & 717.13 & Rajl \\
\hline MILLSTONE-2 & PWR & 41.19 & 72.10 & 1684 & 673.08 & Rai 1 \\
\hline MILLSTONE-3 & PWR & 41.19 & 72.10 & 1125 & 519.22 & $\operatorname{Ra} i 1$ \\
\hline CONNECTICUT YANKEE & PWR & 41.39 & 72.30 & 1592 & 653.43 & Truck \\
\hline VERMONT YANKEE & $B W R$ & 42.47 & 72.31 & 3259 & 595.01 & Rail \\
\hline SHOREHAM & BWR & 40.58 & 72.52 & 2611 & 478.94 & Truck \\
\hline YANKEE & PWR & 42.44 & 72.56 & 818 & 192.42 & Truck \\
\hline INDIAN POINT-I & PWR & 41.16 & 73.57 & 160 & 30.60 & Truck \\
\hline INDIAN POINT-2 & PWR & 41.16 & 73.57 & 1460 & 663.53 & Truck \\
\hline INOIAN POINT-3 & PWR & 41.16 & 73.57 & 1310 & 599.53 & Truck \\
\hline OYSTER CREEK & $B W R$ & 39.49 & 74.12 & 4429 & 794.11 & Truck \\
\hline HOPE CREEK -1 & BWR & 39.43 & 75.28 & 3828 & 696.63 & Truck \\
\hline SALEM-1 & PWR & 39.28 & 75.32 & 1458 & 672.72 & Truck \\
\hline SALEM-2 & PWR & 39.28 & 75.32 & 1417 & 680.77 & Truck \\
\hline LIMER ICK - 1 & BWR & 40.15 & 75.39 & 3559 & 650.97 & Rail \\
\hline SUSQUEHANNA-1 & $B W R$ & 41.06 & 76.09 & 3972 & 706.01 & Rail \\
\hline SUSQUEHANNA-2 & $B W R$ & 41.06 & 76.09 & 3802 & 675.78 & Rai 1 \\
\hline PEACH BOTTOM-2 & BWR & 39.45 & 76.16 & 5341 & 972.32 & Rai1 \\
\hline PEACH BOTTOM- 3 & $\mathrm{BWR}$ & 39.45 & 76.16 & 5337 & 971.20 & Rail \\
\hline CALVERT CLIFFS-1 & PWR & 38.26 & 76.26 & 1637 & 631.62 & Truck \\
\hline CALVERT CLIFFS-2 & PWR & 38.26 & 76.26 & 1559 & 602.46 & Truck \\
\hline NINE MILE POINT-1 & BWR & 43.27 & 76.26 & 3511 & 635.18 & Rail \\
\hline NINE MILE POINT-2 & BWR & 43.27 & 76.26 & 3245 & 582.59 & $\operatorname{Ra} 11$ \\
\hline FITZPATRICK & BWR & 43.27 & 76.26 & 4021 & 736.37 & Rail \\
\hline SURRY-1 & PWR & 37.10 & 76.42 & 1282 & 583.23 & Truck \\
\hline SURRY -2 & PWR & 37.10 & 76.42 & 1196 & 545.53 & Truck \\
\hline THREE MILE ISLAND-1 & PWR & 40.10 & 76.44 & 1408 & 652.26 & Rail \\
\hline GINNA & PWR & 43.17 & 77.19 & 982 & 357.46 & Truck \\
\hline NORTH ANNA-1 & PWR & 38.03 & 77.47 & 1297 & 596.54 & Rail \\
\hline NORTH ANNA-2 & PWR & 38.03 & 77.47 & 1217 & 559.74 & Rail \\
\hline BRIJNSWICK -2 & BWR & 33.58 & 78.01 & 3447 & 644.85 & $\operatorname{Raj} 1$ \\
\hline BRUNSWICK-1 & BWR & 33.58 & 78.01 & 3411 & 637.82 & Rail \\
\hline BRUNSWICK-2 POOL (b) & PWR & 33.58 & 78.01 & 144 & 65.60 & Rail \\
\hline BRUNSWICK-1 POOL (b) & PWR & 33.58 & 78.01 & 160 & 71.30 & Rail \\
\hline HARR IS -1 & PWR & 35.35 & 78.55 & 923 & 424.57 & Rail \\
\hline WEST VALLEY-BWR (c) & $B W R$ & 42.50 & 78.60 & 85 & 11.10 & Rail \\
\hline WEST VALLEY-PWR (C) & PWR & 42.50 & 78.60 & 121 & 47.29 & RaiT \\
\hline ROBINSON-2 & PWR & 34.24 & 80.10 & 1150 & 494.64 & Rail \\
\hline ST. LUCIE-1 & PWR & 27.21 & 80.15 & 1623 & 599.20 & Truck \\
\hline ST. LUCIE-2 & PWiR & 27.21 & 80.15 & 1323 & 502.65 & Truck \\
\hline TURKEY POINT-3 & PWR & 25.26 & 80.20 & 1331 & 608.48 & Truck \\
\hline TURKEY POINT-4 & PWR & 25.26 & 80.20 & 1404 & 642.74 & Truck \\
\hline BEAVER VALLEY-1 & PWR & 40.37 & 80.26 & 1322 & 609.83 & Rail \\
\hline
\end{tabular}


TABLE C.2. (contd)

\begin{tabular}{|c|c|c|c|c|c|c|}
\hline Facility & Type & $\begin{array}{l}\text { North } \\
\text { Latitude } \\
\end{array}$ & $\begin{array}{c}\text { West } \\
\text { Longitude }\end{array}$ & $\begin{array}{l}\text { Number of } \\
\text { As semblies }\end{array}$ & $\begin{array}{c}\text { Metric } \\
\text { Tons } \\
\end{array}$ & $\begin{array}{c}\text { Shippjing } \\
\text { Mode }\end{array}$ \\
\hline BEAVER VALLEY-2 & PWR & 40.37 & 80.26 & 980 & 452.36 & Rail \\
\hline MC GUIRE-1 & PWR & 35.26 & 80.57 & 1343 & 575.92 & Rail \\
\hline MC GUIRE-2 & PWR & 35.26 & 80.57 & 1266 & 541.98 & Rail \\
\hline CATAWBA-1 & PWR & 35.03 & 81.04 & 1221 & 517.26 & Rail \\
\hline CATAWBA-2 & PWR & 35.03 & 81.04 & 1065 & 451.16 & Rai \\
\hline PERRY - 1 & $B W R$ & 41.48 & 81.09 & 4184 & 763.10 & Ra†1 \\
\hline PERRY - 2 & BWR & 41.48 & 81.09 & 3151 & 569.89 & Raj 1 \\
\hline SUMMER & PWR & 34.18 & 81.19 & 1194 & 526.57 & Rai 1 \\
\hline VOGTLE - 1 & PWR & 33.09 & 81.46 & 1255 & 578.48 & Rail \\
\hline HATCH-1 & BWR & 31.56 & 82.21 & 4090 & 747.79 & Rail \\
\hline HATCH-2 & BWR & 31.56 & 82.21 & 3884 & 707.49 & Raji \\
\hline CRYSTAL RIVER-3 & PWR & 28.57 & 82.42 & 1294 & 600.49 & Truck \\
\hline OCONEE-1 & PWR & 34.48 & 82.54 & 1460 & 677.40 & Truck \\
\hline OCONEE-2 & PWR & 34.48 & 82.54 & 1171 & 542.92 & Truck \\
\hline OCONEE - 3 & PWR & 34.48 & 82.54 & 1504 & 698.07 & Truck \\
\hline DAVIS-BESSE-1 & PWR & 41.36 & 83.05 & 1029 & 482.63 & Rail \\
\hline FERMI - 2 & BWR & 41.58 & 83.16 & 3643 & 662.67 & Rail \\
\hline MIDLAND-2 & PWR & 43.36 & 84.14 & 819 & 381.22 & Rail \\
\hline WATTS BAR - 1 & PWR & 35.41 & 84.52 & 1162 & 517.12 & Rail \\
\hline WATTS BAR-2 & PWR & 35.41 & 84.52 & 1043 & 464.33 & Rail \\
\hline SEQUOYAH-1 & PWR & 35.14 & 85.05 & 1407 & 620.68 & Rajl \\
\hline SEQUOYAH-2 & PWR & 35.14 & 85.05 & 1401 & 623.51 & Rail \\
\hline FARLEY-1 & PWR & 31.13 & 85.06 & 1434 & 660.98 & Rail \\
\hline FARLEY-2 & PWR & 31.13 & 85.06 & 1289 & 592.58 & Rai 1 \\
\hline BIG ROCK POINT & BWR & 45.19 & 85.15 & 613 & 79.34 & Rail \\
\hline BELLEFONTE-1 & PWR & 34.43 & 85.56 & 1153 & 507.57 & Rail \\
\hline BELLEFONTE-2 & PWR & 34.43 & 85.56 & 865 & 381.47 & Rail \\
\hline PALISADES & PWR & 42.24 & 86.16 & 1513 & 595.92 & Rail \\
\hline DC COOK-1 & PWR & 41.57 & 86.32 & 1704 & 768.93 & Rai 1 \\
\hline D C COOK -2 & PWR & 41.57 & 86.32 & 1669 & 696.43 & Rail \\
\hline KEWAUNEE & PWR & 44.21 & 87.32 & 1227 & 473.34 & Truck \\
\hline POINT BEACH-1 & PINR & 44.17 & 87.33 & 1219 & 452.66 & Truck \\
\hline POINT BEACH-2 & PWR & 44.17 & 87.33 & 1121 & 417.18 & Truck \\
\hline BROWNS FERRY-1 & $B W R$ & 34.35 & 87.35 & 4705 & 832.58 & Truck \\
\hline BROWNS FERRY-2 & $B W R$ & 34.35 & 87.35 & 4511 & 796.93 & Truck \\
\hline BROWNS FERRY-3 & BWR & 34.35 & 87.35 & 4375 & 776.44 & Truck \\
\hline ZION-1 & PWR & 42.27 & 87.48 & 1618 & 739.62 & Rail \\
\hline ZION-2 & PWR & 42.27 & 87.48 & 1590 & 726.86 & Rail \\
\hline BRAIDWOOD-1 & PWR & 41.15 & 88.13 & 1159 & 490.03 & Rail \\
\hline BRA IDW00D-2 & PWR & 41.15 & 88.13 & 972 & 410.99 & Rail \\
\hline DRESDEN-1 & BWR & 41.24 & 88.17 & 683 & 69.00 & Rail \\
\hline DRESDEN-2 & BWR & 41.24 & 89.17 & 4350 & 786.81 & Rail \\
\hline DRE SDEN-3 & BWR & 41.24 & 88.17 & 3842 & 705.88 & Rail \\
\hline LA SALLE-1 & BWR & 41.15 & 88.40 & 3577 & 652.02 & Rail \\
\hline LA SALLE-2 & BWR & 41.15 & 88.40 & 3391 & 618.17 & Rail \\
\hline CL INTON-1 & $B W R$ & 40.10 & 88.50 & 3157 & 577.41 & Rał1 \\
\hline
\end{tabular}


TABLE C.2. (contd)

\begin{tabular}{|c|c|c|c|c|c|c|}
\hline Facility & Type & $\begin{array}{l}\text { North } \\
\text { Lati tude } \\
\end{array}$ & $\begin{array}{c}\text { West } \\
\text { Longitude } \\
\end{array}$ & $\begin{array}{l}\text { Number of } \\
\text { Assemblies }\end{array}$ & $\begin{array}{c}\text { Metric } \\
\text { Tons } \\
\end{array}$ & $\begin{array}{l}\text { Shipping } \\
\text { Mode }\end{array}$ \\
\hline MORRIS-BWR (c) & BWR & 41.30 & 88.50 & 753 & 145.23 & RaiT \\
\hline MORRIS-PWR $(C)$ & PWR & 41.30 & 88.50 & 350 & 133.70 & Rail \\
\hline BYRON-1 & PWR & 42.05 & 89.17 & 1288 & 544.57 & Rail \\
\hline BYRON-2 & PWR & 42.05 & 89.17 & 1194 & 504.86 & Rail \\
\hline QUAO CITIES-1 & BWR & 41.44 & 90.19 & 4065 & 730.03 & Rail \\
\hline QUAD CITIES-2 & $B W R$ & 41.44 & 90.19 & 3807 & 686.80 & Rail \\
\hline WATERFORD-3 & PWR & 30.00 & 90.28 & 1364 & 578.06 & Rail \\
\hline GRAND GULF-1 & $B W R$ & 32.00 & 91.03 & 4143 & 731.00 & Rail \\
\hline LA CROSSE & BWR & 43.41 & 91.14 & 810 & 89.82 & Rail \\
\hline RIVER BEND-1 & BWR & 30.45 & 91.20 & 3422 & 608.46 & Rail \\
\hline CALLAWAY - 1 & PWR & 38.46 & 91.47 & 1330 & 568.66 & Rail \\
\hline DUANE ARNOLD & $B W R$ & 42.02 & 91.48 & 2498 & 458.93 & Rail \\
\hline PRAIRIE ISLAND-1 & PWR & 44.37 & 92.38 & 1267 & 506.80 & Rail \\
\hline PRAIRIE ISLAND-2 & PWR & 44.37 & 92.38 & 1254 & 501.60 & Rail \\
\hline ARKANSAS NUCL ONE-1 & PWR & 35.19 & 93.13 & 1409 & 652.78 & Rail \\
\hline ARKANSAS NUCL ONE-2 & PWR & 35.19 & 93.13 & 1140 & 486.10 & Rail \\
\hline MONTICELLO & BWR & 45.20 & 93.50 & 3269 & 590.21 & Rai \\
\hline COOPER & BWR & 40.20 & 95.38 & 3522 & 649.40 & Rail \\
\hline WOLF CREEK & PWR & 38.14 & 95.41 & 1047 & 483.07 & Rail \\
\hline SOUTH TEXAS PROJ-1 & PWR & 28.48 & 96.03 & 1197 & 644.49 & Rail \\
\hline FORT CALHOUN-I & PWR & 41.31 & 96.05 & 1012 & 363.96 & Truck \\
\hline COMANCHE PEAK-1 & PWR & 32.14 & 97.45 & 1408 & 580.75 & Rail \\
\hline COMANCHE PEAK-2 & PWR & 32.14 & 97.45 & 1348 & 555.96 & Rail \\
\hline PALO VERDE-1 & PWR & 33.23 & 112.52 & 1471 & 635.99 & Rail \\
\hline PALO VERDE-2 & PWR & 33.23 & 112.52 & 1419 & 613.16 & $\operatorname{Ra} \mp 1$ \\
\hline PAL0 VERDE-3 & PWR & 33.23 & 112.52 & 1322 & 570.29 & Rail \\
\hline SAN ONOFRE-1 & PWR & 33.22 & 117.33 & 804 & 297.00 & Rail \\
\hline SAN ONOFRE-2 & PWR & 33.22 & 117.33 & 1056 & 441.97 & Rail \\
\hline SAN ONOFRE-3 & PWR & 33.22 & 117.33 & 982 & 411.19 & Rail \\
\hline WNP - 2 & BWR & 46.40 & 119.34 & 3911 & 707.43 & Truck \\
\hline DIABLO CANYON-2 & PWR & 35.12 & 120.48 & 1124 & 516.03 & Truck \\
\hline DIABLO CANYON-1 & PWR & 35.12 & 120.48 & 1159 & 532.05 & Truck \\
\hline RANCHO SECO-1 & PWR & 38.20 & 121.10 & 1363 & 632.52 & Rail \\
\hline TROJAN & PWR & 46.02 & 122.52 & 1428 & 658.49 & Truck \\
\hline HUMBOLDT BAY & $B W R$ & 40.43 & 124.14 & 434 & 30.99 & Rail \\
\hline
\end{tabular}

\footnotetext{
(a) Facilities are designated as shipping by rail, except where current cask handling capabilities or site access limitations allow shipment only by truck.

(b) Areas within Brunswick pools designated for storage of PWR spent fuel transshipped from other reactors.

(c) Away-from-reactor spent fuel storage facilities.
} 
TABLE C.3. Spent Fuel Information for All Projected Spent Fuel at All Reactors

\begin{tabular}{|c|c|c|c|c|c|c|}
\hline Facility & Type & $\begin{array}{l}\text { North } \\
\text { Latitude } \\
\end{array}$ & $\begin{array}{c}\text { West } \\
\text { Longitude }\end{array}$ & $\begin{array}{l}\text { Number of } \\
\text { Assemblies }\end{array}$ & $\begin{array}{l}\text { Metric } \\
\text { Tons } \\
\end{array}$ & $\begin{array}{l}\text { Shipping } \\
\text { Mode }\end{array}$ \\
\hline MAINE YANKEE & PWR & 43.57 & 69.42 & 2158 & 810.87 & Rail \\
\hline PILGRIM-1 & BWR & 41.57 & 70.35 & 4342 & 781.05 & Truck \\
\hline SEABROOK - 1 & PWR & 42.54 & 70.51 & 2488 & 1053.56 & Rail \\
\hline MILLSTONE-1 & BWR & 41.19 & 72.10 & 4563 & 819.53 & Rail \\
\hline MILLSTONE-2 & PWR & 41.19 & 72.10 & 2171 & 869.14 & Rail \\
\hline MILLSTONE-3 & PWR & 41.19 & 72.10 & 2158 & 995.96 & Rajl \\
\hline CONNECTICUT YANKEE & PWR & 41.39 & 72.30 & 1592 & 653.43 & Truck \\
\hline VERMONT YANKEE & BWR & 42.47 & 72.31 & 3797 & 693.25 & Rail \\
\hline SHOREHAM & BWR & 40.58 & 72.52 & 4689 & 859.91 & Truck \\
\hline YANKEE & PWR & 42.44 & 72.56 & 818 & 192.42 & Truck \\
\hline INDIAN POINT-1 & PWR & 41.16 & 73.57 & 160 & 30.60 & Truck \\
\hline INDIAN POINT-2 & PWR & 41.16 & 73.57 & 1720 & 781.95 & Truck \\
\hline INDIAN POINT-3 & PWR & 41.16 & 73.57 & 1718 & 783.49 & Truck \\
\hline OYSTER CREEK & $B W R$ & 39.49 & 74.12 & 4429 & 794.11 & Truck \\
\hline HOPE CREEK - 1 & BWR & 39.43 & 75.28 & 7130 & 1297.53 & Truck \\
\hline SALEM-1 & PWR & 39.28 & 75.32 & 1793 & 827.40 & Truck \\
\hline SALEM-2 & PWR & 39.28 & 75.32 & 1768 & 842.07 & Truck \\
\hline LIMER ICX-1 & BWR & 40.15 & 75.39 & 6677 & 1218.39 & Rajl \\
\hline SUSOUEHANNA-1 & $B W R$ & 41.06 & 76.09 & 6622 & 1173.94 & Rajl \\
\hline SUSOUEHANNA-2 & BWR & 41.06 & 76.09 & 6687 & 1185.21 & Rail \\
\hline PEACH BOTTOM-2 & $B W R$ & 39.45 & 76.16 & 6342 & 1154.56 & Rail \\
\hline PEACH BOTTOM-3 & BWR & 39.45 & 76.16 & 6338 & 1153.37 & Rail \\
\hline CALVERT CLIFFS-1 & PWR & 38.26 & 76.26 & 1988 & 768.26 & Truck \\
\hline CALVERT CLIFFS-2 & PWR & 38.26 & 76.26 & 1910 & 739.10 & Truck \\
\hline NINE MILE POINT-1 & BWR & 43.27 & 76.26 & 4043 & 729.08 & Rail \\
\hline NINE MILE POINT-2 & BWR & 43.27 & 76.26 & 6259 & 1123.52 & Rail \\
\hline FITZPATRICK & BWR & 43.27 & 76.26 & 5138 & 939.74 & Rail \\
\hline SURRY -1 & PWR & 37.10 & 76.42 & 1439 & 654.83 & Truck \\
\hline SURRY -2 & PWR & 37.10 & 76.42 & 1466 & 668.66 & Truck \\
\hline THREE MILE ISLAND-1 & PWR & 40.10 & 76.44 & 1727 & 800.02 & Rail \\
\hline GINNA & PWR & 43.17 & 77.19 & 1129 & 408.91 & Truck \\
\hline NORTH ANNA-1 & PWR & 38.03 & 77.47 & 1713 & 787.90 & Rail \\
\hline NORTH ANNA-2 & PWR & 38.03 & 77.47 & 1632 & 750.64 & Rail \\
\hline BRUNSWICK -2 & $B W R$ & 33.58 & 78.01 & 4509 & 843.45 & Raji \\
\hline BRUNSWICK-1 & BWR & 33.58 & 78.01 & 4472 & 836.23 & Rail \\
\hline BRUNSWICK-2 POOL. (b) & PWR & 33.58 & 78.01 & 144 & 65.60 & Rail \\
\hline BRUNSWICK-1 POOL (b) & PWR & 33.58 & 78.01 & 160 & 71.30 & Rail \\
\hline HARRIS -1 & PWR & 35.35 & 78.55 & 1619 & 744.73 & Raj 1 \\
\hline WEST VALLEY-BWR (C) & BWR & 42.50 & 78.60 & 85 & 11.10 & Rail \\
\hline WEST VALLEY-PWR (C) & PWR & 42.50 & 78.60 & 121 & 47.29 & Raji \\
\hline ROBINSON-2 & PWR & 34.24 & 80.10 & 1356 & 583.22 & Rai 1 \\
\hline ST. LUCIE-I & PWR & 27.21 & 80.15 & 2069 & 761.73 & Truck \\
\hline ST. LUCIE-2 & PWR & 27.21 & 80.15 & 2151 & 817.68 & Truck \\
\hline TURKEY POINT-3 & PWR & 25.26 & 80.20 & 1548 & 708.08 & Truck \\
\hline TURKEY POINT-4 & PWR & 25.26 & 80.20 & 1619 & 741.43 & Truck \\
\hline
\end{tabular}


TABLE C.3. (contd)

\begin{tabular}{|c|c|c|c|c|c|c|}
\hline Facility & Type & $\begin{array}{c}\text { North } \\
\text { Latitude }\end{array}$ & $\begin{array}{c}\text { West } \\
\text { Longi tude }\end{array}$ & $\begin{array}{l}\text { Number of } \\
\text { Assemblies }\end{array}$ & $\begin{array}{l}\text { Metric } \\
\text { Tons } \\
\end{array}$ & $\begin{array}{l}\text { Shipping } \\
\text { Mode }\end{array}$ \\
\hline BEAVER VALLEY -1 & PWR & 40.37 & 80.26 & 1615 & 745.05 & Rail \\
\hline BEAVER VALLEY -2 & PWR & 40.37 & 80.26 & 1820 & 839.61 & Rail \\
\hline MC GUIRE-1 & PWR & 35.26 & 80.57 & 2001 & 854.65 & Rail \\
\hline MC GUIRE-? & PWR & 35.26 & 80.57 & 1867 & 796.57 & Rail \\
\hline CATAWBA-1 & PWR & 35.03 & 81.04 & 2112 & 894.72 & Rail \\
\hline CATAWBA-2 & PWR & 35.03 & 81.04 & 2175 & 921.38 & Rail \\
\hline PERRY - 1 & BWR & 41.48 & 81.09 & 7701 & 1404.78 & RaiT \\
\hline PERRY -2 & BWR & 41.48 & 81.09 & 6439 & 1169.76 & Rai? \\
\hline SUMMER & PWR & 34.18 & 81.19 & 1691 & 745.47 & Rail \\
\hline VOGTLE-1 & PWR & 33.09 & 81.46 & 2467 & 1137.20 & Rail 1 \\
\hline HATCH-1 & BWR & 31.56 & 82.21 & 5040 & 920.83 & Rail \\
\hline HATCH-2 & $B W R$ & 31.56 & 82.21 & 5332 & 971.25 & Rail \\
\hline CRYSTAL RIVER-3 & PWR & 28.57 & 82.42 & 1591 & 738.19 & Truck \\
\hline OCONEE-1 & PWR & 34.48 & 82.54 & 1692 & 784.95 & Truck \\
\hline OCONEE-2 & PWR & 34.48 & 82.54 & 1411 & 654.20 & Truck \\
\hline OCONEE-3 & PWR & 34.48 & 82.54 & 1744 & 809.35 & Truck \\
\hline DAVIS-BESSE-1 & PWR & 41.36 & 83.05 & 1386 & 649.84 & RaiT \\
\hline FERMI -2 & $B W R$ & 41.58 & 83.16 & 6585 & 1197.83 & Rail \\
\hline MIDLAND-2 & PWR & 43.36 & 84.14 & 1597 & 743.46 & Rail \\
\hline WATTS BAR-1 & PWR & 35.41 & 84.52 & 2068 & 919.63 & Rail \\
\hline WATTS BAR -2 & PWR & 35,41 & 84.52 & 2020 & 898.40 & Rai i \\
\hline SEOUOYAH-1 & PWR & 35.14 & 85.05 & 1834 & 810.38 & Rai \\
\hline SEQUOYAH-2 & PWR & 35.14 & 85.05 & 1828 & 813.21 & Rail \\
\hline FARLEY-1 & PWR & 31.13 & 85.06 & 1864 & 859.28 & Rail \\
\hline FARLEY-2 & PWR & 31.13 & 85.06 & 1719 & 790.28 & Rail \\
\hline BIG ROCK POINT & $B W R$ & 45.19 & 85.15 & 613 & 79.34 & Rail \\
\hline BELLEFONTE - 1 & PWR & 34.43 & 85.56 & 2341 & 1030.08 & Rai ? \\
\hline BELLEFONTE - 2 & PWR & 34.43 & 85.56 & 1846 & 814.74 & Rail \\
\hline PAL ISADES & PWR & 42.24 & 86.16 & 1780 & 699.58 & Rail \\
\hline$D C \mathrm{COOK}-1$ & PWR & 41.57 & 86.32 & 2122 & 960.63 & Rail \\
\hline$D C \quad C O O K-2$ & PWR & 41.57 & 86.32 & 2108 & 874.31 & Rajl \\
\hline KEWAUNEE & PWR & 44.21 & 87.32 & 1452 & 559.66 & Truck \\
\hline POINT BEACH-1 & PWR & 44.17 & 87.33 & 1408 & 519.34 & Truck \\
\hline POINT BEACH-2 & PWR & 44.17 & 87.33 & 1332 & 491.88 & Truck \\
\hline BROWNS FERRY - 1 & BWR & 34.35 & 87.35 & 5676 & 1002.95 & Truck \\
\hline BROWNS FERRY-2 & BWR & 34.35 & 87.35 & 5467 & 964.66 & Truck \\
\hline BROWNS FERRY-3 & BWR & 34.35 & 87.35 & 5547 & 983.44 & Truck \\
\hline ZION-1 & PWR & 42.27 & 87.48 & 1943 & 888.18 & Rail \\
\hline $\mathrm{ZION}-2$ & PWR & 42.27 & 87.48 & 1873 & 856.22 & Rajl \\
\hline BRAIDW00D-1 & PWR & 41.15 & 88.13 & 2207 & 933.13 & Raji \\
\hline BRAIDWOOD-2 & PWR & 41.15 & 88.13 & 1926 & 814.35 & Rail \\
\hline DRESDEN-1 & BWR & 41.24 & 88.17 & 683 & 69.00 & Rail \\
\hline DRESDEN-2 & $B W R$ & 41.24 & 88.17 & 5256 & 949.70 & Rail \\
\hline ORESDEN-3 & BWR & 41.24 & 88.17 & 4566 & 839.23 & Rail \\
\hline LA SALLE-1 & BWR & 41.15 & 88.40 & 6021 & 1097.17 & Rai \\
\hline LA SALLE-2 & BWR & 41.15 & 88.40 & 6024 & 1097.74 & Rail \\
\hline
\end{tabular}


TABLE C.3. (cont d)

\begin{tabular}{|c|c|c|c|c|c|c|}
\hline Facility & Type & $\begin{array}{c}\text { North } \\
\text { Lat itude } \\
\end{array}$ & $\begin{array}{c}\text { West } \\
\text { Longitude } \\
\end{array}$ & $\begin{array}{l}\text { Number of } \\
\text { As semb lies }\end{array}$ & $\begin{array}{c}\text { Metric } \\
\text { Tons } \\
\end{array}$ & $\begin{array}{l}\text { Shipping } \\
\text { Mode }\end{array}$ \\
\hline CL INTON-1 & BWR & 40.10 & 88.50 & 6117 & 1118.74 & Rail \\
\hline MORRIS-BWR ${ }_{(c)}^{(C)}$ & BWR & 41.30 & 88.50 & 753 & 145.23 & Rail \\
\hline MORRIS-PWR (C) & PWR & 41.30 & 88.50 & 350 & 133.70 & Rai 1 \\
\hline BYRON-1 & PWR & 42.05 & 89.17 & 2180 & 921.70 & Rail \\
\hline BYRON-2 & PWR & 42.05 & 89.17 & 2235 & 945.00 & Rai 1 \\
\hline QUAD CITIES-1 & $B W R$ & 41.44 & 90.19 & 4789 & 857.59 & Rail \\
\hline QUAD CITIES-2 & BWR & 41.44 & 90.19 & 4531 & 814.37 & Rai 1 \\
\hline WATERFORD-3 & PWR & 30.00 & 90.28 & 2394 & 1016.11 & Rail \\
\hline GRAND GULF-1 & BWR & 32.00 & 91.03 & 7169 & 1263.99 & Rail \\
\hline LA CROSSE & BWR & 43.41 & 91.14 & 810 & 89.82 & Rail \\
\hline RIVER BEND-1 & BWR & 30.45 & 91.20 & 6048 & 1072.28 & Rai 1 \\
\hline CALLAWAY -1 & PWR & 38.46 & 91.47 & 2270 & 966.28 & Raji \\
\hline DUANE ARNOLD & BWR & 42.02 & 91.48 & 3200 & 587.27 & Rail \\
\hline PRAIRIE ISLAND-1 & PWR & 44.37 & 92.38 & 1488 & 595.20 & Rail \\
\hline PRAIRIE ISLAND-2 & PWR & 44.37 & 92.38 & 1449 & 579.60 & Rail \\
\hline ARKANSAS NUCL ONE-1 & PWR & 35.19 & 93.13 & 1712 & 793.14 & Raii \\
\hline ARKANSAS NUCL ONE -2 & PWR & 35.19 & 93.13 & 1543 & 657.98 & Rail \\
\hline MONT ICELLO & $B W R$ & 45.20 & 93.50 & 3947 & 710.13 & Rail \\
\hline COOPER & BWR & $4 D .20$ & 95.38 & 4383 & 806.98 & Rail \\
\hline WOLF CREEK & PWR & 38.14 & 95.41 & 1850 & 853.53 & Rail \\
\hline SOUTH TEXAS PROJ-1 & PWR & 28.48 & 96.03 & 2373 & 1277.69 & Rail \\
\hline FORT CALHOUN-1 & PWR & 41.31 & 96.05 & 1186 & 426.09 & Truck \\
\hline COMANCHE PEAK-1 & PWR & 32.14 & 97.45 & 2449 & 1000.41 & Raj 1 \\
\hline COMANCHE PEAK-2 & PWR & 32.14 & 97.45 & 2505 & 1022.38 & Rai \\
\hline PALO VERDE-1 & PWR & 33.23 & 112.52 & 2563 & 1112.35 & Rail \\
\hline PAL0 VERDE-2 & PWR & 33.23 & 112.52 & 2512 & 1089.96 & Rail \\
\hline PALO VERDE - 3 & PWR & 33.23 & 112.52 & 2590 & 1123.41 & Rai 1 \\
\hline SAN ONOFRE-1 & PWR & 33.22 & 117.33 & 804 & 297.00 & Rail \\
\hline SAN ONOFRE-2 & PWR & 33.22 & 117.33 & 1573 & 658.61 & Rai 1 \\
\hline SAN ONOFRE-3 & PWR & 33.22 & 117.33 & 1725 & 722.48 & Rail \\
\hline WNP - 2 & BWR & 46.40 & 119.34 & 6877 & 1245.93 & Truck \\
\hline DIABLO CANYON-2 & PWR & 35.12 & 120.48 & 2040 & 936.52 & Truck \\
\hline DIABLO CANYON-1 & PWR & 35.12 & 120.48 & 2070 & 950.25 & Truck \\
\hline RANCHO SECO-1 & PWR & 38.20 & 121.10 & 1644 & 763.00 & Rail \\
\hline TROJAN & PWR & 46.02 & 12.2 .52 & 1893 & 872.89 & Truck \\
\hline HUMBOLDT BAY & BWR & 40.43 & 124.14 & 434 & 30.99 & Rail \\
\hline
\end{tabular}

\footnotetext{
(a) Facilities are designated as shipping by rail, except where current cask handling capabilities or site access limitations allow shipment only by

(b) Areas within Brunswick pools designated for storage of PWR spent fuel transshipped from other reactors.

(c) Away-from-reactor spent fuel storage facilities.
} 
TABLE C.4. Spent Fuel Information for 01dest 70,000 MTU Spent Fue1 Excluding Western Reactors

\begin{tabular}{|c|c|c|c|c|c|c|}
\hline Facility & Type & $\begin{array}{l}\text { North } \\
\text { Latitude } \\
\end{array}$ & $\begin{array}{c}\text { West } \\
\text { Longitude } \\
\end{array}$ & $\begin{array}{l}\text { Number of } \\
\text { Assemblies }\end{array}$ & $\begin{array}{l}\text { Metric } \\
\text { Tons } \\
\end{array}$ & $\begin{array}{l}\text { Shipping } \\
\text { Mode }\end{array}$ \\
\hline MAINE YANKEE & PWR & 43.57 & 69.42 & 1941 & 729.47 & Rail \\
\hline PILGRIM-1 & BWR & 41.57 & 70.35 & 3762 & 678.25 & Truck \\
\hline SEABROOK-1 & PWR & 42.54 & 70.51 & 1455 & 616.15 & Rail \\
\hline MILLSTONE-1 & BWR & 41.19 & 72.10 & 4563 & 819.53 & Rajl \\
\hline MILLSTONE-2 & PWR & 41.19 & 72.10 & 1819 & 727.36 & Rail \\
\hline MILLSTONE-3 & PWR & 41.19 & 72.10 & 1245 & 574.60 & Rail \\
\hline CONNECTICUT YANKEE & PWR & 41.39 & 72.30 & 1592 & 653.43 & Truck \\
\hline VERMONT YANKEE & BWR & 42.47 & 72.31 & 3797 & 693.25 & Rajl \\
\hline SHOREHAM & BWR & 40.58 & 72.52 & 2778 & 509.56 & Truck \\
\hline YANKEE & PWR & 42.44 & 72.56 & 818 & 192.42 & Truck \\
\hline INDIAN POINT-1 & PWR & 41.16 & 73.57 & 160 & 30.60 & Truck \\
\hline INDIAN POINT-2 & PWR & 41.16 & 73.57 & 1720 & 781.95 & Truck \\
\hline INDIAN POINT-3 & PWR & 41.16 & 73.57 & 1452 & 664.56 & Truck \\
\hline OYSTER CREEX & BWR & 39.49 & 74.12 & 4429 & 794.11 & Truck \\
\hline HOPE CREEK-1 & 8WR & 39.43 & 75.28 & 4079 & 742.31 & Truck \\
\hline SALEM-1 & PWR & 39.28 & 75.32 & 1600 & 738.30 & Truck \\
\hline SALEM-2 & PWR & 39.28 & 75.32 & 1496 & 717.07 & Truck \\
\hline LIMER ICK-I & $B W R$ & 40.15 & 75.39 & 3792 & 693.37 & Rajl \\
\hline SUSQUEHANNA-1 & BWR & 41.06 & 76.09 & 4438 & 788.29 & Rail \\
\hline SUSQUEHANNA-2 & $B W R$ & 41.06 & 76.09 & 4035 & 716.92 & Rail \\
\hline PEACH BOTTOM-2 & BWR & 39.45 & 76.16 & 5578 & 1015.46 & Rajl \\
\hline PEACH BOTTOM-3 & BWR & 39.45 & 76.16 & 5574 & 1014.33 & Rail \\
\hline CALVERT CLIFFS-1 & PWR & 38.26 & 76.26 & 1704 & 657.70 & Truck \\
\hline CALVERT CLIFFS-2 & PWR & 38.26 & 76.26 & 1626 & 628.54 & Truck \\
\hline NINE MILE POINT-1 & BWR & 43.27 & 76.26 & 4043 & 729.08 & Rail \\
\hline NINE MILE POINT-2 & BWR & 43.27 & 76.26 & 3493 & 627.10 & Rail \\
\hline FITZPATRICK & BWR & 43.27 & 76.26 & 4391 & 803.71 & Rail \\
\hline SURRY -1 & PWR & 37.10 & 76.42 & 1282 & 583.23 & Truck \\
\hline SURRY -2 & PWR & 37.10 & 76.42 & 1253 & 571.52 & Truck \\
\hline THREE MILE ISLAND-1 & PWR & 40.10 & 76.44 & 1479 & 685.14 & Rail \\
\hline GINNA & PWR & 43.17 & 77.19 & 1129 & 408.91 & Truck \\
\hline NORTH ANNA-1 & PWR & 38.03 & 77.47 & 1426 & 655.88 & Rail \\
\hline NORTH ANNA-2 & PWR & 38.03 & 77.47 & 1346 & 619.08 & Rail \\
\hline BRUNSWICK-2 & BWR & 33.58 & 78.01 & 3614 & 676.08 & Raj1 \\
\hline BRUNSWICK-1 & $B W R$ & 33.58 & 78.01 & 3578 & 669.05 & Rajl \\
\hline BRUNSWICK -2 POOL (b) & PWR & 33.58 & 78.01 & 144 & 65.60 & Rail \\
\hline BRUNSWICK-1 POOL (b) & PWR & 33.58 & 78.01 & 160 & 71.30 & Rai 1 \\
\hline HARRIS -1 & PWR & 35.35 & 78.55 & 971 & 446.65 & Rail \\
\hline WEST VALLEY-BWR (C) & BWR & 42.50 & 78.60 & 85 & 11.10 & Rajl \\
\hline WEST VALLEY-PWR (c) & PWR & 42.50 & 78.60 & 121 & 47.29 & Rail \\
\hline ROB I NSON-2 & PWR & 34.24 & 80.10 & 1356 & 583.22 & Rail \\
\hline ST. LUCIE-1 & PWR & 27.21 & 80.15 & 1776 & 654.94 & Truck \\
\hline ST. LUCIE-2 & PWR & 27.21 & 80.15 & 1475 & 560.49 & Truck \\
\hline TURKEY POINT-3 & PWR & 25.26 & 80.20 & 1548 & 708.08 & Truck \\
\hline TURKEY POINT-4 & PWR & 25.26 & 80.20 & 1619 & 741.43 & Truck \\
\hline
\end{tabular}


TABLE C.4. (contd)

\begin{tabular}{|c|c|c|c|c|c|c|}
\hline Facility & Type & $\begin{array}{c}\text { North } \\
\text { Latitude }\end{array}$ & $\begin{array}{c}\text { West } \\
\text { Longitude }\end{array}$ & $\begin{array}{l}\text { Number of } \\
\text { Assemblies }\end{array}$ & $\begin{array}{l}\text { Metric } \\
\text { Tons }\end{array}$ & $\begin{array}{l}\text { Shippjing } \\
\text { Mode }\end{array}$ \\
\hline BEAVER VALLEY-1 & PWR & 40.37 & 80.26 & 1458 & 672.59 & RaiT \\
\hline BEAVER VALLEY $Y-2$ & PWR & 40.37 & 80.26 & 1048 & 483.71 & Rail \\
\hline MC GUIRE-1 & PWR & 35.26 & 80.57 & 1457 & 624.21 & Raj 1 \\
\hline MC GUIRE-2 & PWR & 35.26 & 80.57 & 1382 & 591.12 & Rajl \\
\hline CATAWBA-1 & PWR & 35.03 & 81.04 & 1278 & 541.41 & Raj \\
\hline CATAWBA-2 & PWR & 35.03 & 81.04 & 1179 & 499.45 & Rail \\
\hline PERRY - 1 & BWR & 41.48 & 81.09 & 4472 & 815.64 & Rail \\
\hline PERRY - 2 & BWR & 41.48 & 81.09 & 3699 & 669.87 & Rajl \\
\hline SUMMER & PWR & 34.18 & 81.19 & 1261 & 556.08 & Rajl \\
\hline VOGTLE-1 & PWR & 33.09 & 81.46 & 1435 & 661.46 & Rajl \\
\hline HATCH-1 & BWR & 31.56 & 82.21 & 4350 & 795.15 & Raj 1 \\
\hline HATCH-2 & BWR & 31.56 & 82.21 & 4244 & 773.07 & Rail \\
\hline CRYSTAL RIVER-3 & PWR & 28.57 & 82.42 & 1354 & 628.31 & Truck \\
\hline OCONEE-1 & PWR & 34.48 & 82.54 & 1692 & 784.95 & Truck \\
\hline OCONEE - 2 & PWR & 34.48 & 82.54 & 1371 & 635.65 & Truck \\
\hline OCONEE-3 & PWR & 34.48 & 82.54 & 1651 & 766.23 & Truck \\
\hline DAV I S-BESSE-1 & PWR & 41.36 & 83.05 & 1119 & 524.79 & Rail \\
\hline FERMI -2 & BWR & 41.58 & 83.16 & 3914 & 711.95 & Rail \\
\hline MIDLAND-2 & PWR & 43.36 & 84.14 & 879 & 409.16 & Raji \\
\hline WATTS BAR-1 & PWR & 35.41 & 84.52 & 1318 & 586.42 & Rail \\
\hline WATTS BAR - 2 & PWR & 35.41 & 84.52 & 1121 & 498.98 & Rail \\
\hline SEQUOYAH-1 & PWR & 35.14 & 85.05 & 1485 & 655.33 & Rail \\
\hline SEQUOYAH $\rightarrow 2$ & PWR & 35.14 & 85.05 & 1479 & 658.16 & Raíl \\
\hline FARLEY -1 & PWR & 31.13 & 85.06 & 1501 & 691.88 & RaiT \\
\hline FARLEY - 2 & PWR & 31.13 & 85.06 & 1357 & 623.84 & Rail \\
\hline BIG ROCK POINT & BWR & 45.19 & 85.15 & 613 & 79.34 & Rail \\
\hline BELLEFONTE - 1 & PWR & 34.43 & 85.56 & 1242 & 546.79 & Rail \\
\hline BELLEFONTE-2 & PWR & 34.43 & 85.56 & 1043 & 460.09 & Rajl \\
\hline PALISADES & PWR & 42.24 & 86.16 & 1780 & 699.58 & Rail \\
\hline D C COOK -1 & PWR & 41.57 & 86.32 & 1854 & 837.73 & Raj 1 \\
\hline D C COOK -2 & PWR & 41.57 & 86.32 & 1833 & 763.05 & Rail \\
\hline KEWAUNEE & PWR & 44.21 & 87.32 & 1331 & 513.26 & Truck \\
\hline POINT BEACH-1 & PWR & 44.17 & 87.33 & 1408 & 519.34 & Truck \\
\hline POINT BEACH-2 & PWR & 44.17 & 87.33 & 1182 & 438.77 & Truck \\
\hline BROWNS FERRY-1 & BWR & 34.35 & 87.35 & 5676 & 1002.95 & Truck \\
\hline BROWNS FERRY-2 & BWR & 34.35 & 87.35 & 5467 & 964.66 & Truck \\
\hline BROWNS FERRY -3 & BWR & 34.35 & 87.35 & 4783 & 848.50 & Truck \\
\hline ZION-1 & PWR & 42.27 & 87.48 & 1708 & 780.76 & Rail \\
\hline ZION-2 & PWR & 42.27 & 87.48 & 1680 & 768.00 & Rail \\
\hline BRAIDWOOD-1 & PWR & 41.15 & 88.13 & 1318 & 557.26 & Rail \\
\hline BRAIDWOOD-2 & PWR & 41.15 & 88.13 & 1085 & 458.77 & Raji \\
\hline DRESDEN-1 & $B W R$ & 41.24 & 88.17 & 683 & 69.00 & Rail \\
\hline DRESDEN-2 & BWR & 41.24 & 88.17 & 5256 & 949.70 & Rail \\
\hline DRE SDEN-3 & BWR & 41.24 & 88.17 & 4566 & 839.23 & Rajl \\
\hline LA SALLE-1 & BWR & 41.15 & 88.40 & 3784 & 689.72 & Raj \\
\hline LA SALLE-2 & BWR & 41.15 & 88.40 & 3788 & 690.47 & Rail \\
\hline
\end{tabular}


TABLE C.4. (contd)

\begin{tabular}{|c|c|c|c|c|c|c|}
\hline Facility & Type & $\begin{array}{c}\text { North } \\
\text { Latitude }\end{array}$ & $\begin{array}{c}\text { West } \\
\text { Longitude }\end{array}$ & $\begin{array}{l}\text { Number of } \\
\text { Assemblies }\end{array}$ & $\begin{array}{l}\text { Metric } \\
\text { Tons }\end{array}$ & $\begin{array}{l}\text { Shipping } \\
\text { Mode }\end{array}$ \\
\hline CLINTON-1 & BWR & 40.10 & 88.50 & 3579 & 654.59 & Rail \\
\hline MORRIS-BWR (C) & BWR & 41.30 & 88.50 & 753 & 145.23 & Raj \\
\hline MORRIS-PWR (C) & PWR & 41.30 & 88.50 & 350 & 133.70 & Rail \\
\hline BYRON-1 & PWR & 42.05 & 89.17 & 1394 & 589.39 & Raił \\
\hline BYRON-2 & PWR & 42.05 & 89.17 & 1346 & 569.13 & Rail \\
\hline QUAD CITIES-1 & BWR & 41.44 & 90.19 & 4789 & 857.59 & Rail \\
\hline QUAO CITIES-2 & BWR & 41.44 & 90.19 & 4531 & 814.37 & Rail \\
\hline WATERFORD-3 & PWR & 30.00 & 90.28 & 1497 & 634.59 & Rail \\
\hline GRAND GULF-1 & BWR & 32.00 & 91.03 & 4387 & 773.98 & Rail \\
\hline LA CROSSE & BWR & 43.41 & 91.14 & 810 & 89.82 & Rail \\
\hline RIVER BEND-1 & BWR & 30.45 & 91.20 & 3707 & 658.43 & Raj 1 \\
\hline CALLAWAY -1 & PWR & 38.46 & 91.47 & 1412 & 603.35 & Rail \\
\hline DUANE ARNOLD & $B W R$ & 42.02 & 91.48 & 2720 & 499.51 & Rail \\
\hline PRAIRIE ISLAND-1 & PWR & 44.37 & 92.38 & 1341 & 536.40 & Raj \\
\hline PRAIRIE ISLAND-2 & PWR & 44.37 & 92.38 & 1328 & 531.20 & Rail \\
\hline ARKANSAS NUCL ONE-1 & PWR & 35.19 & 93.13 & 1535 & 711.14 & Rail \\
\hline ARKANSAS NUCL ONE-2 & PWR & 35.19 & 93.13 & 1196 & 509.98 & Rail \\
\hline MONTICELLO & BWR & 45.20 & 93.50 & 3947 & 710.13 & Rail \\
\hline COOPER & BWR & 40.20 & 95.38 & 3731 & 687.65 & Rai 1 \\
\hline WOLF CREEK & PWIR & 38.14 & 95.41 & 1114 & 513.98 & Rail \\
\hline SOUTH TEXAS PROJ-1 & PWR & 28.48 & 96.03 & 1312 & 706.41 & Rail \\
\hline FORT CALHOUN-1 & PWR & 41.31 & 96.05 & 1053 & 378.59 & Truck \\
\hline COMANCHE PEAK-1 & PWR & 32.14 & 97.45 & 1588 & 653.32 & Rai1 \\
\hline COMANCHE PEAK-2 & PWR & 32.14 & 97.45 & 1468 & 604.34 & Rail \\
\hline
\end{tabular}

\footnotetext{
(a) Facilities are designated as shipping by rail, except where current cask handling capabilities or site access limitations allow shipment only by

(b) Areas within Brunswick pools designated for storage of PWR spent fuel transshipped from other reactors.

(c) Away-from-reactor spent fuel storage facilities.
} 
TABLE C.5. Spent Fuel Information for A11 Projected Spent Fuel Excluding Western Reactors

\begin{tabular}{|c|c|c|c|c|c|c|}
\hline Facility & Type & $\begin{array}{c}\text { North } \\
\text { Latitude } \\
\end{array}$ & $\begin{array}{c}\text { West } \\
\text { Longitude }\end{array}$ & $\begin{array}{l}\text { Number of } \\
\text { As semb lies }\end{array}$ & $\begin{array}{l}\text { Metric } \\
\text { Tons } \\
\end{array}$ & $\begin{array}{l}\text { Shipping } \\
\text { Mode }\end{array}$ \\
\hline MAINE YANKEE & PWR & 43.57 & 69.42 & 2158 & 810.87 & Rajl \\
\hline PILGR IM-1 & BWR & 41.57 & 70.35 & 4342 & 781.05 & Truck \\
\hline SEABROOK - 1 & PWR & 42.54 & 70.51 & 2488 & 1053.56 & $\operatorname{Rai} 1$ \\
\hline MILLSTONE -1 & BWR & 41.19 & 72.10 & 4563 & 819.53 & Rail \\
\hline MILLSTONE-2 & PWR & 41.19 & 72.10 & 2171 & 869.14 & Rail \\
\hline MILLSTONE-3 & PWR & 41.19 & 72.10 & 2158 & 995.96 & Rail \\
\hline CONNECTICUT YANKEE & PWR & 41.39 & 72.30 & 1592 & 653.43 & Truck \\
\hline VERMONT YANKEE & BWR & 42.47 & 72.31 & 3797 & 693.25 & Rail \\
\hline SHOREHAM & BWR & 40.58 & 72.52 & 4689 & 859.91 & Truck \\
\hline YANKEE & PWR & 42.44 & 72.56 & 818 & 192.42 & Truck \\
\hline INDIAN POINT-1 & PWR & 41.16 & 73.57 & 160 & 30.60 & Truck \\
\hline INDIAN POINT-2 & PWR & 41.16 & 73.57 & 1720 & 781.95 & Truck \\
\hline INDIAN POINT- 3 & PWR & 41.16 & 73.57 & 1718 & 783.49 & Truck \\
\hline OYSTER CREEK & BWR & 39.49 & 74.12 & 4429 & 794.11 & Truck \\
\hline HOPE CREEK-1 & $B W R$ & 39.43 & 75.28 & 7130 & 1297.53 & Truck \\
\hline SALEM-1 & PWR & 39.28 & 75.32 & 1793 & 827.40 & Truck \\
\hline SALEM-2 & PWR & 39.28 & 75.32 & 1768 & 842.07 & Truck \\
\hline LIMER ICK-1 & BWR & 40.15 & 75.39 & 6677 & 1218.39 & Rail \\
\hline SUSQUEHANNA-1 & $B W R$ & 41.06 & 76.09 & 6622 & 1173.94 & Raj 1 \\
\hline SUSQUEHANNA-2 & BWR & 41.06 & 76.09 & 6687 & 1185.21 & Rail \\
\hline PEACH BOTTOM-2 & BWR & 39.45 & 76.16 & 6342 & 1154.56 & Rajl \\
\hline PEACH BOTTOM-3 & BWR & 39.45 & 76.16 & 6338 & 1153.37 & Raji \\
\hline CALVERT CLIFFS-1 & PWR & 38.26 & 76.26 & 1988 & 768.26 & Truck \\
\hline CALVERT CLIFFS-2 & PWR & 38.26 & 76.26 & 1910 & 739.10 & Truck \\
\hline NINE MILE POINT-1 & BWR & 43.27 & 76.26 & 4043 & 729.08 & Raj \\
\hline NINE MILE POINT-2 & $\mathrm{BWR}$ & 43.27 & 76.26 & 6259 & 1123.52 & Rajl \\
\hline FITZPATRICK & BWR & 43.27 & 76.26 & 5138 & 939.74 & Rai? \\
\hline SURRY $\rightarrow 1$ & PWR & 37.10 & 76.42 & 1439 & 654.83 & Truck \\
\hline SURRY -2 & PWR & 37.10 & 76.42 & 1466 & 668.66 & Truck \\
\hline THREE MILE ISLAND-1 & PWR & 40.10 & 76.44 & 1727 & 800.02 & Rajl \\
\hline GINNA & PWR & 43.17 & 77.19 & 1129 & 408.91 & Truck \\
\hline NORTH ANNA-1 & PWR & 38.03 & 77.47 & 1713 & 787.90 & Raji \\
\hline NORTH ANNA-2 & PWR & 38.03 & 77.47 & 1632 & 750.64 & Rail \\
\hline BRUNSWICK-2 & BWR & 33.58 & 78.01 & 4509 & 843.45 & Rail \\
\hline BRUNSWICK-1 & BWR & 33.58 & 78.01 & 4472 & 836.23 & Rail \\
\hline BRUNSWICK-2 POOL (b) & PWR & 33.58 & 78.01 & 144 & 65.60 & Raji \\
\hline BRUNSWICK-1 POOL (b) & PWR & 33.58 & 78.01 & $\begin{array}{l}144 \\
160\end{array}$ & 71.30 & Rail \\
\hline HARRIS -1 & PWR & 35.35 & 78.55 & 1619 & 744.73 & Rai \\
\hline WEST VALLEY-BWR (C) & BWR & 42.50 & 78.60 & $\begin{array}{r}1017 \\
85\end{array}$ & 11.10 & Raji \\
\hline WEST VALLEY-PWR (c) & PWR & 42.50 & 78.60 & 121 & 47.29 & Raji \\
\hline ROBINSON-2 & PWR & 34.24 & & 1356 & 583.22 & Rail \\
\hline ST. LUCIE-1 & PWR & 27.21 & 80.15 & 2069 & 761.73 & Truck \\
\hline ST. LUCIE-2 & PWR & 27.21 & 80.15 & 2151 & 817.68 & Truck \\
\hline TURKEY POINT-3 & PWR & 25.26 & & 1548 & 708.08 & Truck \\
\hline TURKEY POINT-4 & PWR & 25.26 & 80.20 & 1619 & 741.43 & Truck \\
\hline
\end{tabular}


TABLE C.5. (contd)

\begin{tabular}{|c|c|c|c|c|c|c|}
\hline Facility & Type & $\begin{array}{l}\text { North } \\
\text { Latitude } \\
\end{array}$ & $\begin{array}{c}\text { West } \\
\text { Longitude }\end{array}$ & $\begin{array}{l}\text { Number of } \\
\text { Assemblies }\end{array}$ & $\begin{array}{l}\text { Metric } \\
\text { Tons } \\
\end{array}$ & $\begin{array}{l}\text { Shipping } \\
\text { Mode a }\end{array}$ \\
\hline BEAVER VALLEY-1 & PWR & 40.37 & 80.26 & 1615 & 745.05 & Rail \\
\hline BEAVER VALLEY-2 & PWR & 40.37 & 80.26 & 1820 & 839.61 & Rail \\
\hline MC GUIRE-1 & PWR & 35.26 & 80.57 & 2001 & 854.65 & Rail 1 \\
\hline MC GUIRE-2 & PWR & 35.26 & 80.57 & 1867 & 796.57 & Rail \\
\hline CATAWBA-1 & PWR & 35.03 & 81.04 & 2112 & 894.72 & Rail \\
\hline CATAWBA-2 & PWR & 35.03 & 81.04 & 2175 & 921.38 & Rai \\
\hline PERRY - 1 & $B W R$ & 41.48 & 81.09 & 7701 & 1404.78 & Rai 1 \\
\hline PERRY-2 & BWR & 41.48 & 81.09 & 6439 & 1169.76 & Rail \\
\hline SUMMER & PWR & 34.18 & 81.19 & 1691 & 745.47 & Rail \\
\hline VOGTLE-1 & PWR & 33.09 & 81.46 & 2467 & 1137.20 & Rail \\
\hline HATCH-1 & BWR & 31.56 & 82.21 & 5040 & 920.83 & $\operatorname{Ra} 11$ \\
\hline HATCH-2 & BWR & 31.56 & 82.21 & 5332 & 971.25 & Raji \\
\hline CRYSTAL RIVER-3 & PWR & 28.57 & 82.42 & 1591 & 738.19 & Truck \\
\hline OCONEE-I & PWR & 34.48 & 82.54 & 1692 & 784.95 & Truck \\
\hline OCONEE-2 & PWR & 34.48 & 82.54 & 1411 & 654.20 & Truck \\
\hline OCONEE - 3 & PWR & 34.48 & 82.54 & 1744 & 809.35 & Truck \\
\hline DAVIS-BESSE-1 & PWR & 41.36 & 83.05 & 1386 & 649.84 & Rail \\
\hline FERMI -2 & BWR & 41.58 & 83.16 & 6585 & 1197.83 & Raj \\
\hline MIDLAND-2 & PWR & 43.36 & 84.14 & 1597 & 743.46 & Rail \\
\hline WATTS BAR-1 & PWR & 35.41 & B4. .52 & 2068 & 919.63 & Rail \\
\hline WATTS BAR-2 & PWR & 35.41 & 84.52 & 2020 & 898.40 & Rail \\
\hline SEQUOYAH-I & PWR & 35.14 & 85.05 & 1834 & 810.38 & Rail \\
\hline SEQUOYAH-2 & PWR & 35.14 & 85.05 & 1828 & 813.21 & $\operatorname{Raj} 1$ \\
\hline FARLEY-1 & PWR & 31.13 & 85.06 & 1864 & 859.28 & Rail \\
\hline FARLEY -2 & PWR & 31.13 & 85.06 & 1719 & 790.28 & Rail \\
\hline BIG ROCK POINT & $B W R$ & 45.19 & 85.15 & 613 & 79.34 & Rail \\
\hline BELLEFONTE-1 & PWR & 34.43 & 85.56 & 2341 & 1030.08 & Rail \\
\hline BELLEFONTE-2 & PWR & 34.43 & 85.56 & 1846 & 814.74 & Rail \\
\hline PAL I SADES & PWR & 42.24 & 86.16 & 1780 & 699.58 & Rail 1 \\
\hline D C COOK-I & PWR & 41.57 & 86.32 & 2122 & 960.63 & Rail \\
\hline D C COOK-2 & PWR & 41.57 & 86.32 & 2108 & 874.31 & $\operatorname{Raji}$ \\
\hline KEWAUNEE & PWR & 44.21 & 87.32 & 1452 & 559.66 & Truck \\
\hline POINT BEACH-1 & PWR & 44.17 & 87.33 & 1408 & 519.34 & Truck \\
\hline POINT BEACH-2 & PWR & 44.17 & 87.33 & 1332 & 491.88 & Truck \\
\hline BROWNS FERRY -1 & $B W R$ & 34.35 & 87.35 & 5676 & 1002.95 & Truck \\
\hline BROWNS FERRY -2 & $B W R$ & 34.35 & 87.35 & 5467 & 964.66 & Truck \\
\hline BROWNS FERRY -3 & BWR & 34.35 & 87.35 & 5547 & 983.44 & Truck \\
\hline ZION-1 & PWR & 42.27 & 87.48 & 1943 & 888.18 & Rail \\
\hline ZION-2 & PWR & 42.27 & 87.48 & 1873 & 856.22 & Rail \\
\hline BRAIDW00D-1 & PWR & 41.15 & 88.13 & 2207 & 933.13 & Rail \\
\hline BRAIDWOOD-2 & PWR & 41.15 & 88.13 & 1926 & 814.35 & Rail \\
\hline DRESDEN-1 & $B W R$ & 41.24 & 88.17 & 683 & 69.00 & Rail \\
\hline DRE SDEN-2 & BWR & 41.24 & 88.17 & 5256 & 949.70 & Rail \\
\hline DRESDEN-3 & BWR & 41.24 & 88.17 & 4566 & 839.23 & Rail \\
\hline LA SALLE-1 & BWR & 41.15 & 88.40 & 6021 & 1097.17 & Rail \\
\hline LA SALLE-2 & BWR & 41.15 & 88.40 & 6024 & 1097.74 & Rail \\
\hline
\end{tabular}


TABLE C.5. (contd)

\begin{tabular}{|c|c|c|c|c|c|c|}
\hline Facility & Type & $\begin{array}{l}\text { North } \\
\text { Latitude }\end{array}$ & $\begin{array}{c}\text { West } \\
\text { Longitude }\end{array}$ & $\begin{array}{l}\text { Number of } \\
\text { Assemblies }\end{array}$ & $\begin{array}{l}\text { Metric } \\
\text { Tons } \\
\end{array}$ & $\begin{array}{l}\text { Shipping } \\
\text { Mode }\end{array}$ \\
\hline CL INTON-1 & BWR & 40.10 & 88.50 & 6117 & 1118.74 & Rail \\
\hline MORRIS-BWR (C) & BWR & 41.30 & 88.50 & 753 & 145.23 & Rajl \\
\hline MORRIS-PWR $(C)$ & PWR & 41.30 & 88.50 & 350 & 133.70 & Rai 1 \\
\hline BYRON-1 & PWR & 42.05 & 89.17 & 2180 & 921.70 & Rail \\
\hline BYRON-2 & PWR & 42.05 & 89.17 & 2235 & 945.00 & Rail \\
\hline QUAO CITIES-1 & BWR & 41.44 & 90.19 & 4789 & 857.59 & Rail \\
\hline QUAD CITIES-2 & BWR & 41.44 & 90.19 & 4531 & 814.37 & Rail \\
\hline WATERFORD-3 & PWR & 30.00 & 90.28 & 2394 & 1016.11 & Rail \\
\hline GRAND GULF-1 & BWR & 32.00 & 91.03 & 7169 & 1263.99 & Rail \\
\hline LA CROSSE & BWR & 43.41 & 91.14 & 810 & 89.82 & RaiT \\
\hline RIVER BEND-1 & BWR & 30.45 & 91.20 & 6048 & 1072.28 & Rail \\
\hline CALLAWAY-1 & PWR & 38.46 & 91.47 & 2270 & 966.28 & Rail \\
\hline DUANE ARNOLO & BWR & 42.02 & 91.48 & 3200 & 587.27 & Rail \\
\hline PRAIRIE ISLAND-1 & PWR & 44.37 & 92.38 & 1488 & 595.20 & Rail \\
\hline PRAIRIE ISLAND-2 & PWR & 44.37 & 92.38 & 1449 & 579.60 & Rail \\
\hline ARKANSAS NUCL ONE-1 & PWR & 35.19 & 93.13 & 1712 & 793.14 & Rail \\
\hline ARKANSAS NUCL ONE-2 & PWR & 35.19 & 93.13 & 1543 & 657.98 & Rail \\
\hline MONT ICELLO & BWR & 45.20 & 93.50 & 3947 & 710.13 & Rail \\
\hline COOPER & BWR & 40.20 & 95.38 & 4383 & 806.98 & RaiT \\
\hline WOLF CREEK & PWR & 38.14 & 95.41 & 1850 & 853.53 & Rail \\
\hline SOUTH TEXAS PROJ $=1$ & PWR & 28.48 & 96.03 & 2373 & 1277.69 & Raị 1 \\
\hline FORT CALHOUN-1 & PWR & 41.31 & 96.05 & 1186 & 426.09 & Trixck \\
\hline COMANCHE PEAK-1 & PWR & 32.14 & 97.45 & 2449 & 1000.41 & Rajl \\
\hline COMANCHE PEAK -2 & PWR & 32.14 & 97.45 & 2505 & 1022.38 & Rail \\
\hline
\end{tabular}

\footnotetext{
(a) Facilities are designated as shipping by rail, except where current cask handling capabilities or site access limitations allow shipment only by

(b) Areas within Brunswick pools designated for storage of PWR spent fuel transshipped from other reactors.

(c) Away-from-reactor spent fuel storage facilities.
} 


\section{REFERENCES}

1. C. M. Heeb, R. A. Libby, and G. M. Holter. 1985. Reactor-Specific Spent Fuel Discharge Projections: 1984 to 2020, PNL-5396. Pacific Northwest Laboratory, Richland, Washington.

2. Energy Information Administration. 1984. Commercial Nuclear Power 1984, D0E/EIA-0438(84). U.S. Department of Energy, Washington, D.C.

3. P. M. Daling, et al. 1985. Spent Nuclear Fuel Shipping Cask Handling Capabilities of Commercial Light Water Reactors, PNL-5384. Pacific Northwest Laboratory, Richland, washington. 

APPENDIX D

GEOGRAPHIC DISTRIBUTION OF SPENT FUEL 
APPENDIX D

GEOGRAPHIC DISTRIBUTION OF SPENT FUEL

This appendix provides a discussion of the geographic distribution of the spent fuel to be received at an MRS facility. This distribution has a strong bearing on the location of the preferred siting region. Factors of importance include the locations of the nuclear power reactors and away-from-reactor storage facilities that will ship spent fuel to the MRS facility, the amount of spent fuel to be shipped from each of these, and the shipment mode to be used. The spent fuel projections used for the siting region analyses, which include all of these factors, are presented in detail in Appendix $C$.

Figure D.1 shows a map of the projected distribution of the oldest 70,000 MTU of spent fuel that would be included in shipments to an MRS facility, based on the EIA No New Orders Case. The spent fuel distribution shown on this map is based on the information included in Table C.2 of Appendix C. The locations of the nuclear power reactors that are projected to ship spent fuel to the MRS facility, with corresponding fuel types and shipment modes, are shown in Figure D.2. As shown in the figures, the predominant quantities of spent fuel to be shipped to the MRS facility are located in the eastern half of the U.S.

The location of the geographical center, or centroid, of the spent fuel shipments to the MRS facility provides a useful reference point for discussion of the location and sensitivity of the preferred siting region. The centroid of the spent fuel shipments represents the location of a receiving facility (such as an MRS) that minimizes the total transportation distances (in shipment miles) for shipments to that receiving facility. Stated another way, the centroid marks the location resulting in minimum total shipment miles to the MRS facility, while ignoring subsequent shipments from the MRS facility.

The centroids for projected spent fuel shipments to the MRS facility, for each of the four sets of spent fuel information used for the this study, are shown in Figure D.3. These centroids are based on shipments from each nuclear 


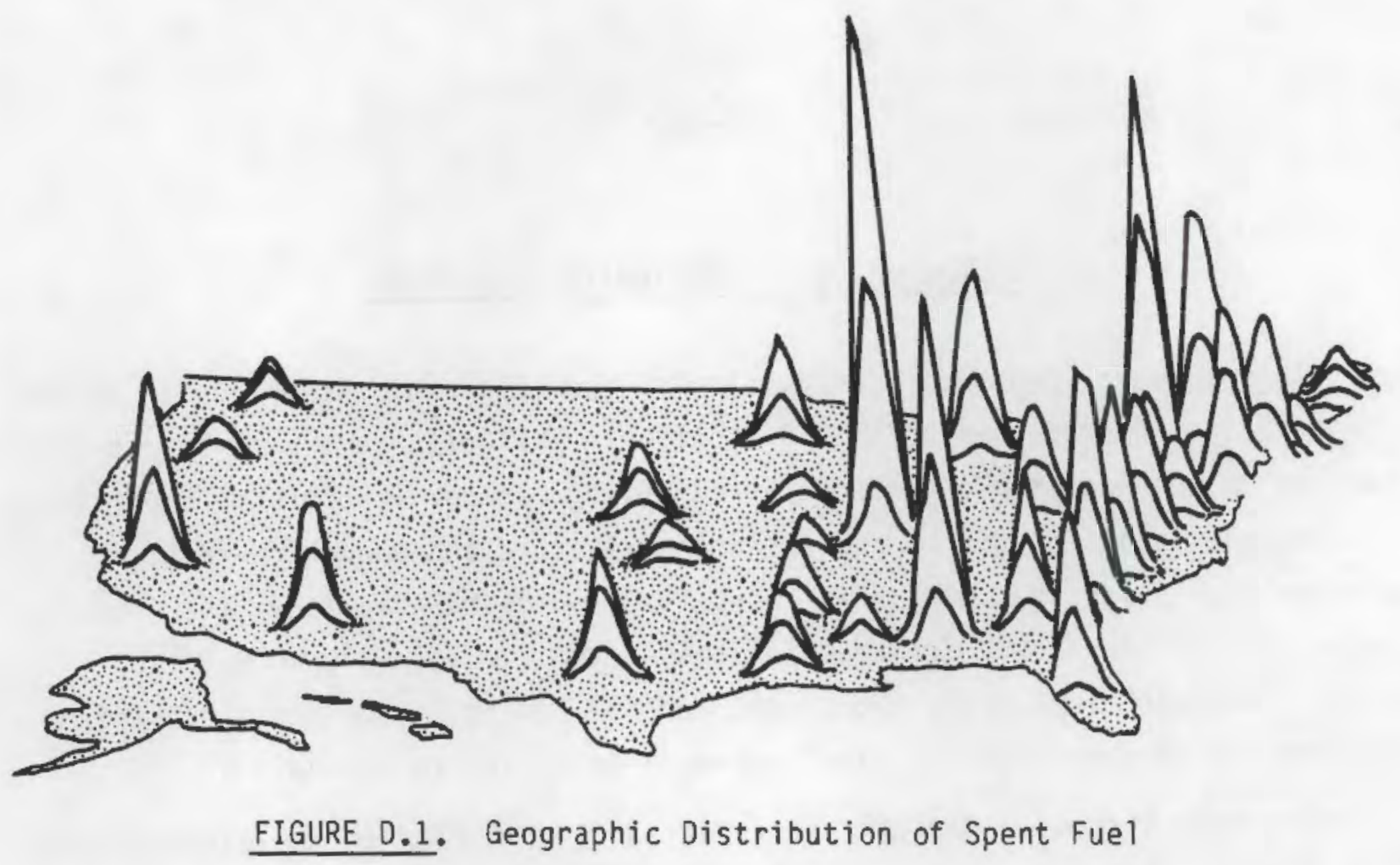

power reactor by the appropriate transport mode for that reactor. As shown in the figure, the centroids for each of the four sets of spent fuel information all lie within a very small region of the eastern U.S.

Because there is little variation in the location of the centroid between the four sets of spent fuel information, it is clear that the selection of the spent fuel information used (from the four sets considered) will have little impact on location of the preferred MRS siting region. 


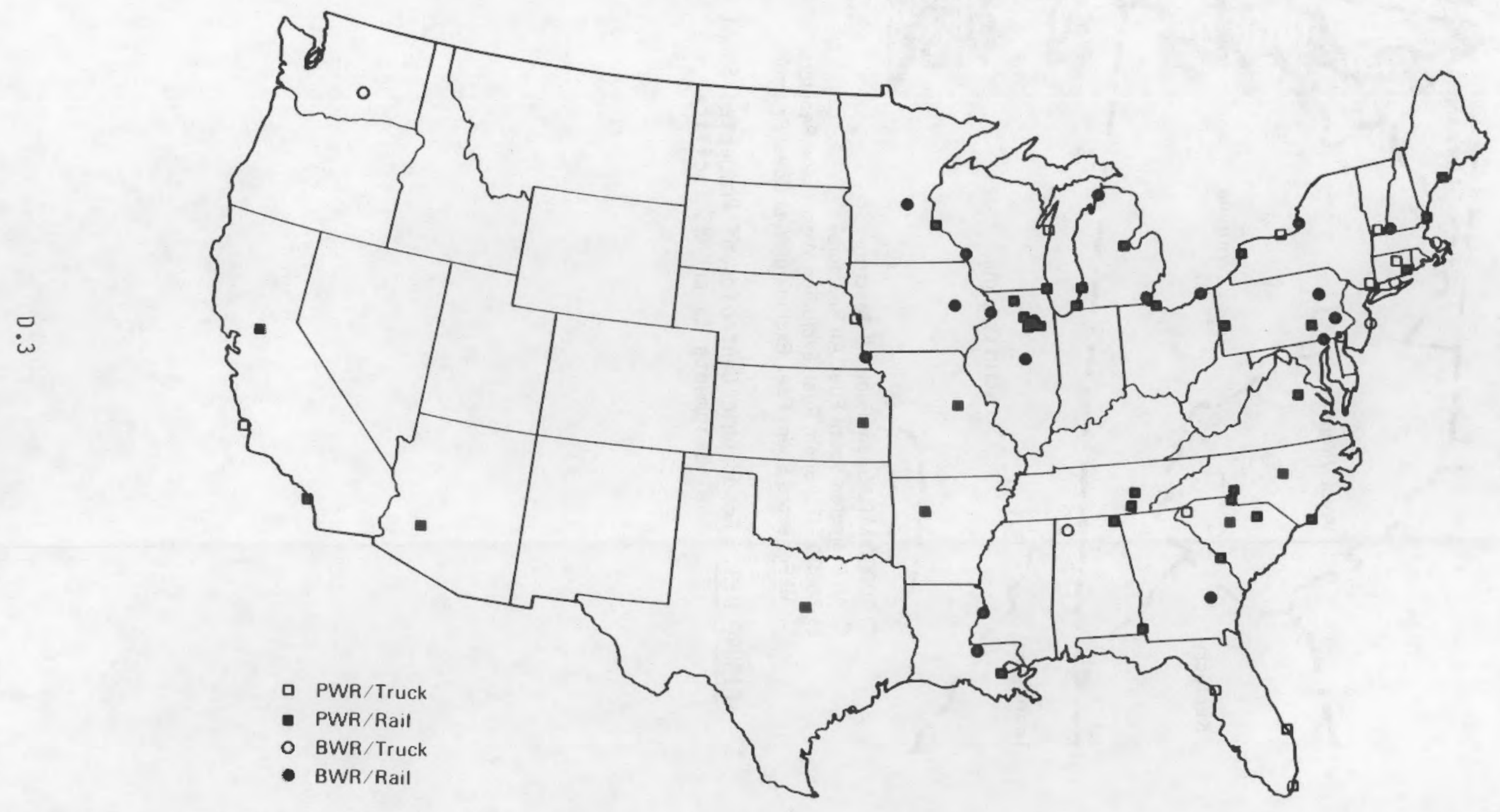

FIGURE D.2. Locations of Nuclear Power Reactors Shipping Spent Fuel to an MRS Facility 


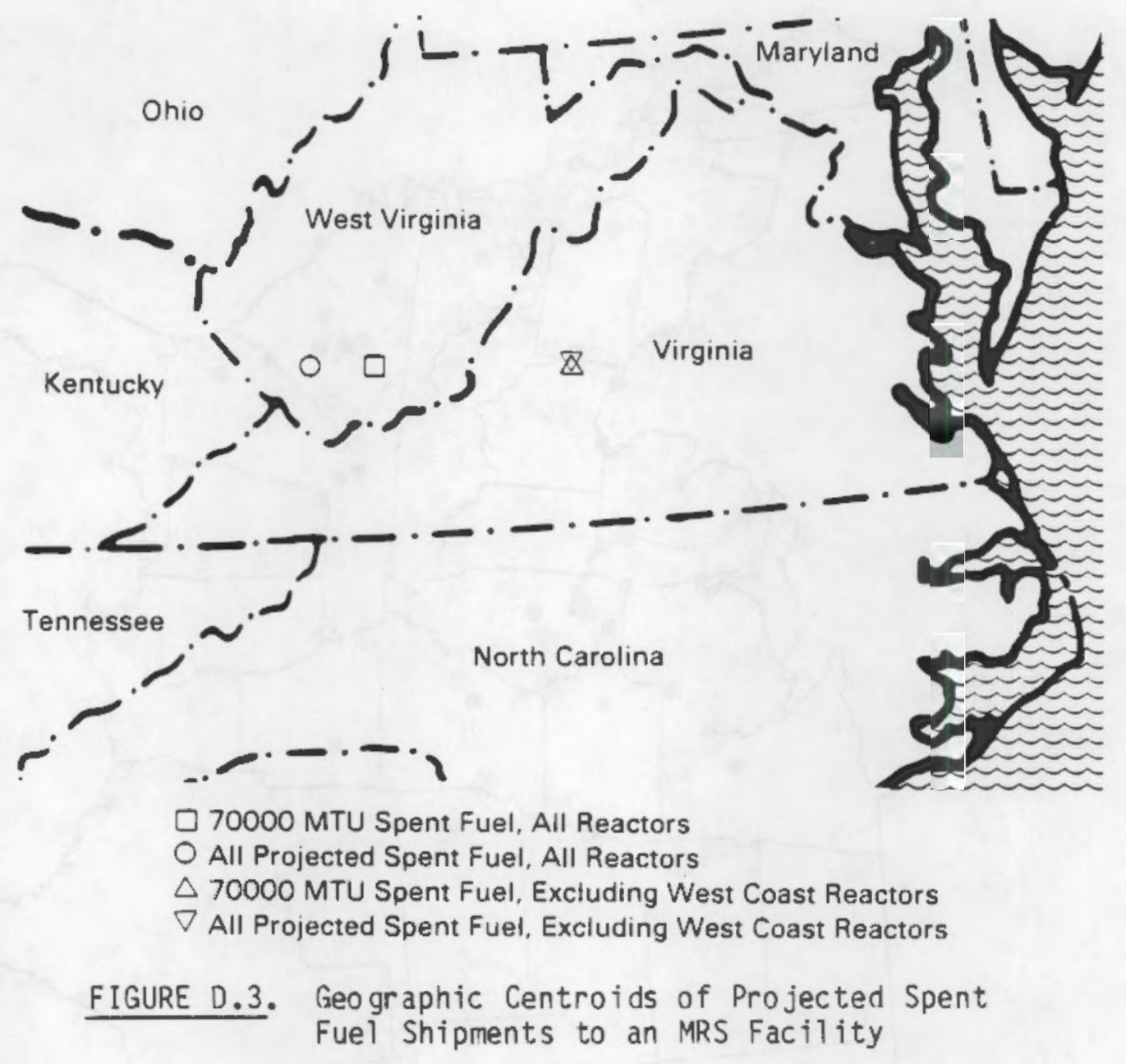




\section{DISTRIBUTION}

No. of

Copies

OFFSITE

6

B. C. Rusche

Office of Civilian Radioactive Waste Management

U.S. Department of Energy

$\mathrm{RW}-1$

Washington, DC 20545

J. R. Hilley

Office of Civilian Radioactive Waste Management

U.S. Department of Energy

$\mathrm{RW}-30$

Washington, DC 20545

K. A. Klein

Office of Civilian Radioactive Waste Management

U.S. Department of Energy

$\mathrm{RW}-31$

Washington, DC 20545

J. H. Carlson

Office of Civilian Radioactive Waste Management

U.S. Department of Energy

$\mathrm{RW}-32$

Washington, DC 20545

2 P. Gross

U.S. Department of Energy

Oak Ridge Operations Office

Oak Ridge, Tennessee 37830

30 DOE Technical Information Center

J. W. Voss

Golder Associates

2950 Northup Way

Bellevue, WA 98004
No. of

Copies

W. D. Woods

The Ralph M. Parsons Company

100 West Walnut St.

Pasadena, CA 91124

R. M. Jefferson

Sandia National Laboratories

Transportation Technology

Center

P.0. Box 5800

Albuquerque, NM 87185

G. C. Allen

Sandia National Laboratories

Transportation Technology

Center

P.0. Box 5800

Albuquerque, MN 87185

ONSITE

5 DOE Richland Operations Office

P. A. Craig (2)

R. B. Goranson

R. D. Izatt

H. E. Ransom

80 Pacific Northwest Laboratory

W. B. Ashton

W. W. Ballard

J. L. Braitman (10)

C. A. Counts

J. F. Fletcher

J. J. Fuquay

R. M. Gale

R. J. Hall

R. E. Heineman

J. N. Holloway

G. M. Holter (25)

D. S. Jackson 
No. of

Copies

W. S. Kelly

D. K. Kreid

M. R. Kreiter

R. A. Libby

R. C. Liikala

J. D. Ludwick

P. N. McDuffie

J. L. McElroy

G. W. McNair

D. F. Newrnan

D. R. Payson

W. D. Richmond

R. E. Rhoads

L. C. Schmid

K. J. Schneider
No. of

Copies

M. J. Scott

R. L. Shaub

M. R. Shay

M. J. Sherbin

D. J. Silviera

A. L. Slavich

R. I. Smith

M. B. Triplett

C. M. Unruh

M. K. White

L. D. Williams

T. W. Wood

J. R. Young

Publishing Coordination MH (2)

Technical Information (5) 